\title{
Potential inhibitors and sources of error in the measurement of travertine precipitation rates in a karst stream influenced by thermal mineral waters
}

\author{
Johnathan E. Moore \\ West Virginia University
}

Follow this and additional works at: https://researchrepository.wvu.edu/etd

\footnotetext{
Recommended Citation

Moore, Johnathan E., "Potential inhibitors and sources of error in the measurement of travertine precipitation rates in a karst stream influenced by thermal mineral waters" (2012). Graduate Theses, Dissertations, and Problem Reports. 4897.

https://researchrepository.wvu.edu/etd/4897

This Thesis is protected by copyright and/or related rights. It has been brought to you by the The Research Repository @ WVU with permission from the rights-holder(s). You are free to use this Thesis in any way that is permitted by the copyright and related rights legislation that applies to your use. For other uses you must obtain permission from the rights-holder(s) directly, unless additional rights are indicated by a Creative Commons license in the record and/ or on the work itself. This Thesis has been accepted for inclusion in WVU Graduate Theses, Dissertations, and Problem Reports collection by an authorized administrator of The Research Repository @ WVU. For more information, please contact researchrepository@mail.wvu.edu.
} 


\title{
Potential inhibitors and sources of error in the measurement of travertine precipitation rates in a karst stream influenced by thermal mineral waters
}

\author{
Johnathan E. Moore \\ Thesis submitted to the \\ Eberly College of Arts and Sciences \\ at West Virginia University \\ in partial fulfillment of the requirements \\ for the degree of
}

Master of Science

in

Geology

Dorothy J. Vesper, Ph.D., Chair

Robert Behling, Ph.D.

Harry M. Edenborn, Ph.D. Jaime Toro, Ph.D.

Department of Geology and Geography

Morgantown, West Virginia

2012

Keywords: $\mathrm{CO}_{2}$; travertine; tufa; thermal mineral spring; kinetics; calcite; PlummerWigley-Parkhurst; inhibitor 


\begin{abstract}
Potential inhibitors and sources of error in the measurement of travertine precipitation rates in a karst stream influenced by thermal mineral waters
\end{abstract}

\author{
Johnathan E. Moore
}

Precipitation rates for travertine have been studied in many natural settings and compared to theoretical calcite $\left(\mathrm{CaCO}_{3}\right)$ precipitation rates; in most studies, the emphasis is placed on the degassing of $\mathrm{CO}_{2}$ as the primary controlling mechanism. Little research has been done in natural settings to evaluate precipitate composition, rates of precipitation, and the role of potential inhibitors of calcite growth. This study addresses these questions in a Sweet Springs Creek, West Virginia-Virginia: a karst stream fed partly by thermal mineral waters with high $\mathrm{CO}_{2}$. For this study, travertine plates were deployed to measure the accretion of precipitates in the presence of natural inhibitors. The mass change on the plates was interpreted as calcite precipitate and converted to precipitation rates by accounting for the plates' length of time in-situ. The Plummer-Wigley-Pinkhurst calcite precipitation rate equation was used to estimate calcite precipitation rates based on bulk water chemistry and compared to the measured plate rates, which were on average one order-of-magnitude lower. SEM-EDS analysis of the mineral precipitate on the travertine plates showed extensive biological activity which correlated with sites with higher variability between calculated and observed precipitation rates. Analysis of precipitate with XRF-Fusion found that $>10 \%$ of the mass in some samples was not calcite. Gypsum selenite $\left(\mathrm{CaSO}_{4} \cdot 2 \mathrm{H}_{2} \mathrm{O}\right)$ crystals were found in addition to detrital quartz on plates surfaces as well, suggesting non-calcite mineral precipitation significant enough to introduce error into estimates. These results suggest that further evaluation of mineral precipitates is needed in order to accurately gauge true precipitation rates in-situ and that previous studies likely underestimated the difference between estimated and actual precipitation rates. 


\section{Acknowledgements}

This work was performed as part of the National Energy Technology Laboratory's Regional University Alliance (NETL-RUA), a collaborative initiative of the NETL, under the RES contract DEFE0004000.

The support of the West Virginia University Department of Geology Geography was an integral and essential part of this research as well. I would like to specifically thank my mentor, Dr. Dorothy Vesper, for her infinite patience and dedication to this research. I would also like to thank Dr. Harry Edenborn, Dr. Jaime Toro, and Dr. Bob Behling for their guidance and support. Additionally, recognition goes to Jim Adams, Andrea Sack, John Tudek, Amanda Laskoskie, and Annie Berlinghieri for their assistance in the field.

I am also thankful for the encouragement and support of my family and wonderful wife Casie. Without their belief in me I would not have been able to complete this thesis.

I would like to thank the kind landowners of the Sweet Springs Valley that allowed us access to their beautiful springs. 


\section{Table of Contents}

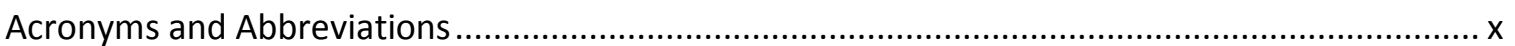

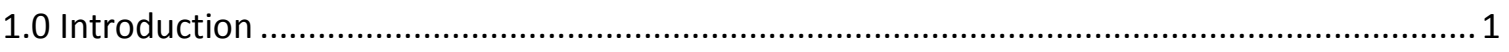

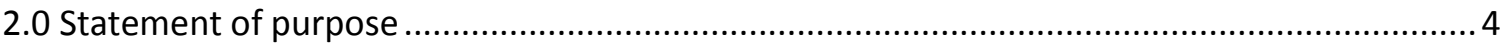

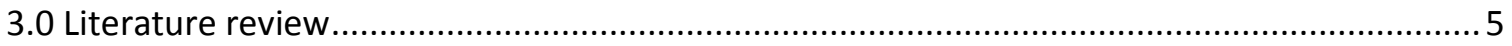

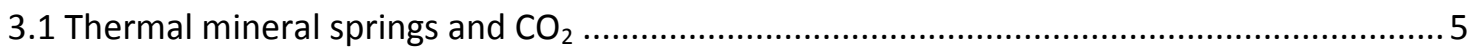

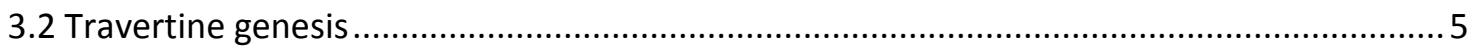

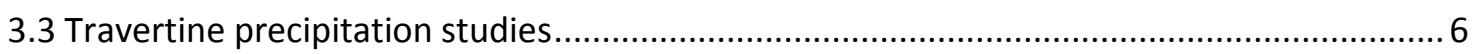

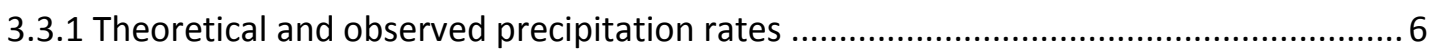

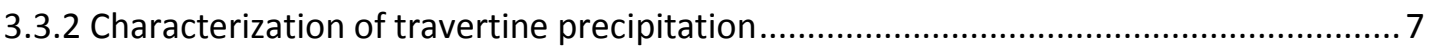

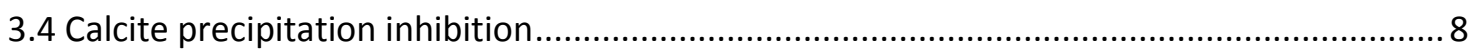

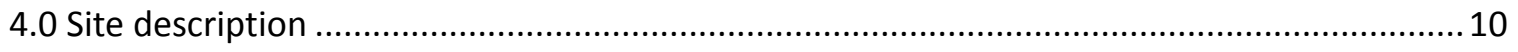

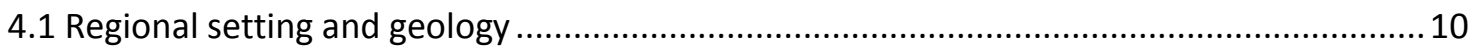

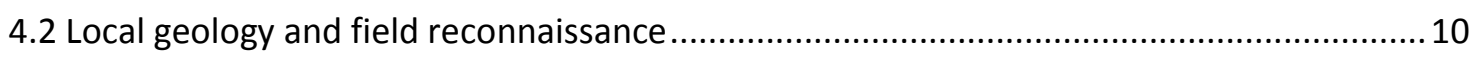

4.3 Detailed description of Sweet Springs Creek .................................................................. 14

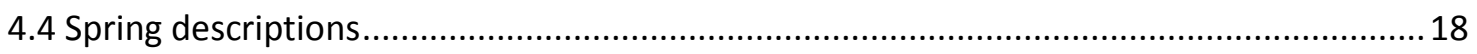

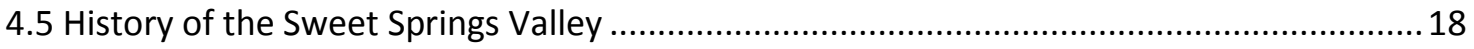

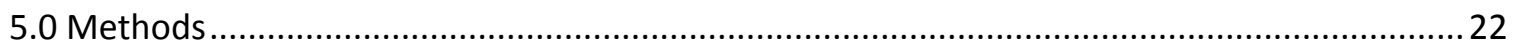

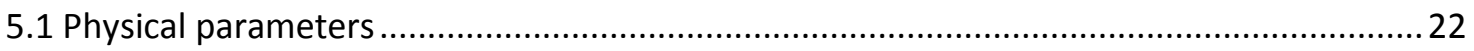

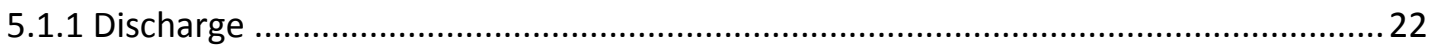

5.1.2 Mineral precipitation plate installation ................................................................. 22

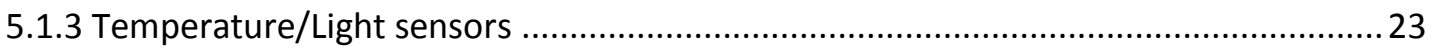

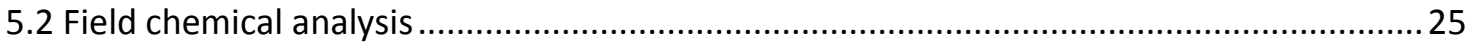

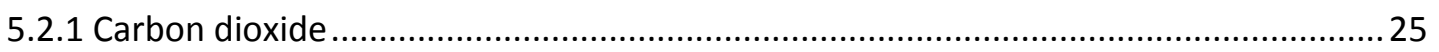

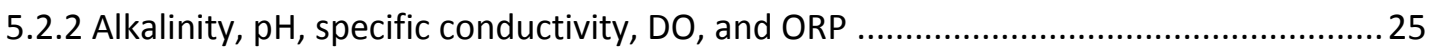

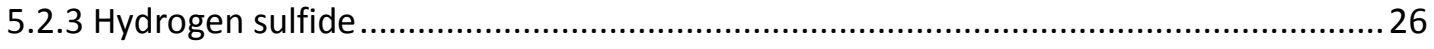

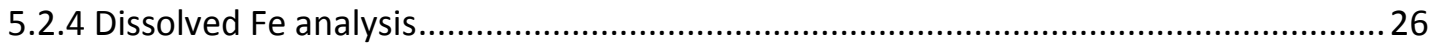

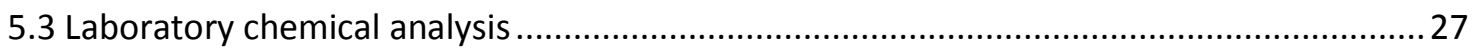

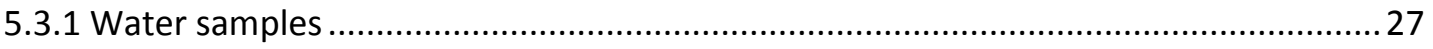

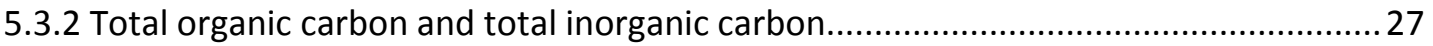

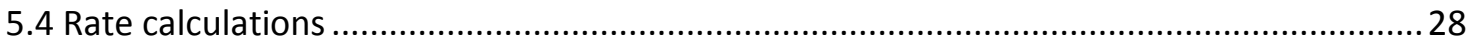

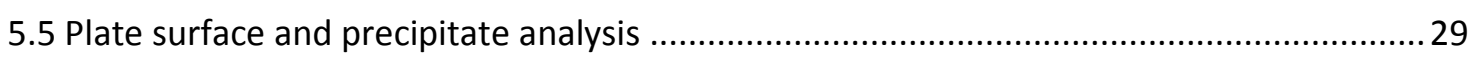

5.5.1 Scanning electron microscope \& electron dispersive spectrometry ............................29

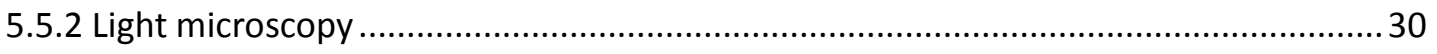

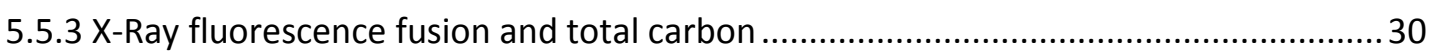




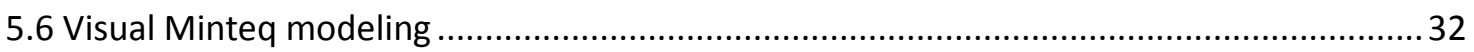

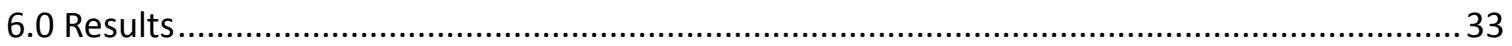

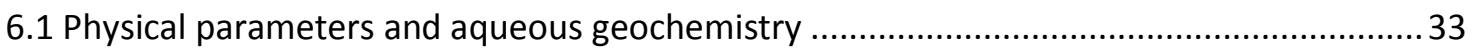

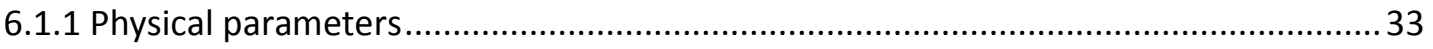

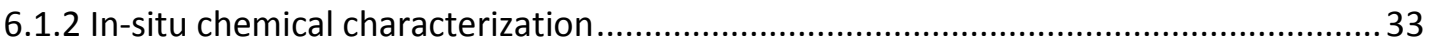

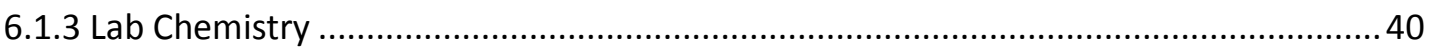

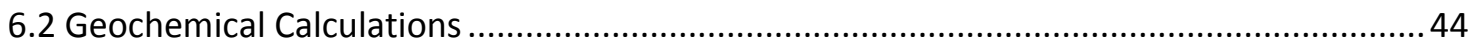

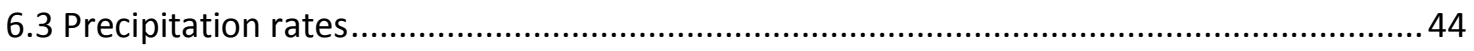

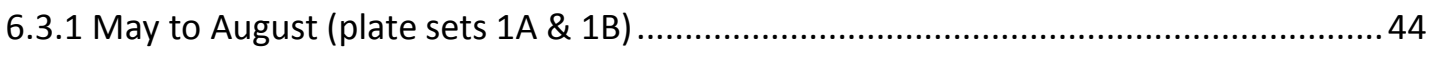

6.3.2 August to September (Plate Set 2) ........................................................................... 44

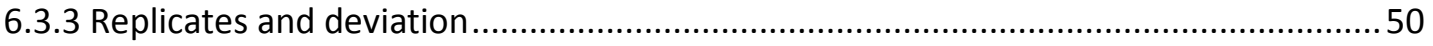

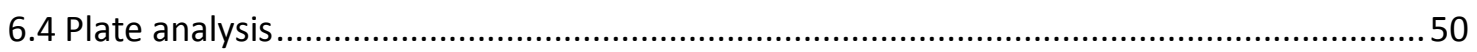

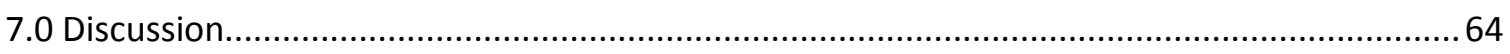

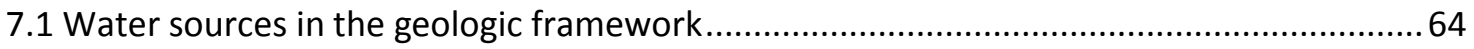

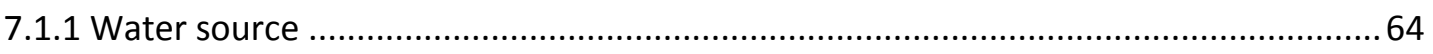

7.1.2 Conceptual model for geology-water interaction ....................................................67

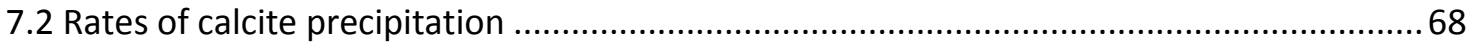

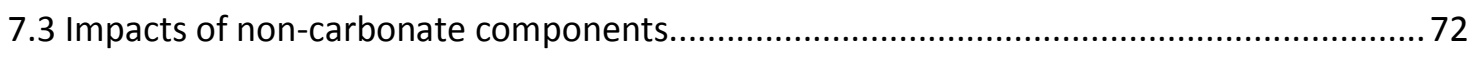

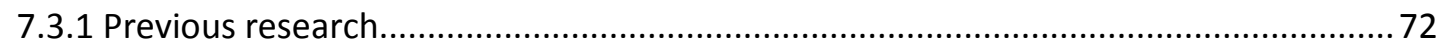

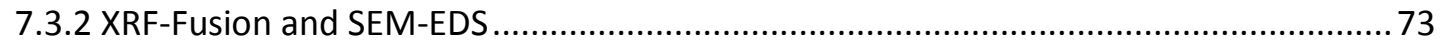

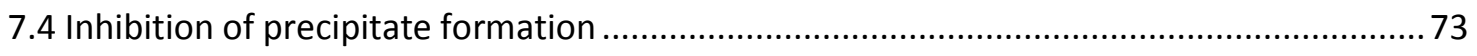

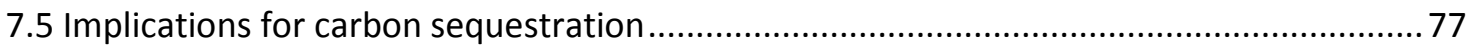

7.6 Inherent limitations in calcite precipitation rate studies............................................... 78

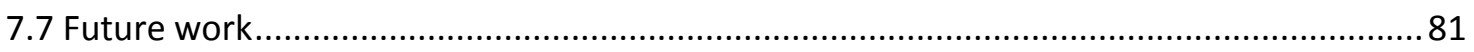

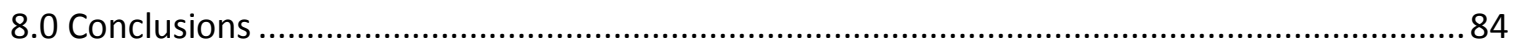

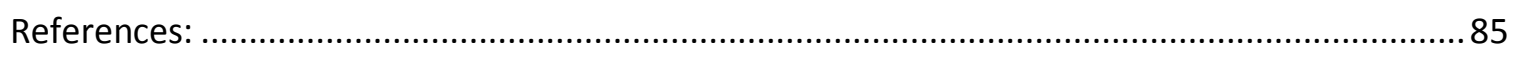

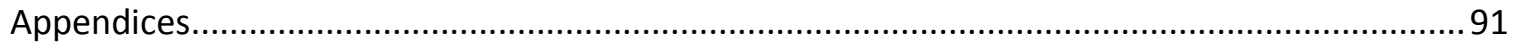




\section{List of Figures}

Figure 1 - Overview of the Sweet Springs Valley study area in West Virginia and Virginia.........11

Figure 2 - Stratigraphic section for Valley and Ridge Province. Modified from (Wilkes, 2002)..12

Figure 3 - Geologic map overlying elevation for the study area.

Figure 4-(A) Image showing the travertine rapids after CREEK3740, (B) image showing the Sawmill Falls escarpment in conjunction with the Sawmill Falls that lie between CREEK6115 and CREEK6150.....

Figure 5 - Outcrop of travertine terrace at the Sawmill Falls Escarpment

Figure 6 - Location of each site relative to Sweet Springs Creek while also comparing their position relative to absolute elevation...

Figure 7 - Map view of Cesspool Cave

Figure 8 - Representation of in-field precipitation plate assembly along with position of temperature sensor.

Figure 9 - Temperature records for (A) CHAL, (B) OLDSWT, (C) CREEK4120, (D) CREEK4010, (E) CREEK3890, and (F) CREEK3740.

Figure 10 - Comparison of $\mathrm{pH}$, Specific Conductivity $(\mathrm{SC})$, and Temperature for all sampling sites.

Figure 11 - Comparison of alkalinity and $\mathrm{CO}_{2}$ for all sampling sites

Figure 12 - Piper diagram showing the general relationships of all samples taken

Figure 13 - Calcite precipitation rates as calculated via the PWP equation and Field-measured rates for plates, May, 2011 to July, 2011

Figure 14 - Calcite precipitation rates as calculated via the PWP equation and field-measured rates for August to September, 2011

Figure 15 - Plates recovered from CREEK6150, below Sawmill Falls, encrusted in loose mineral Precipitate.

Figure 16 - Algae growing on travertine plate surface of a plate installed at CREEK4120 .........53

Figure 17 - (A) Diatoms in matrix of precipitate at CREEK3740, (B) diatom from CREEK3890, (C) broken remains of filamentous diatom in precipitate from CREEK4010, and (D) algae growth in the lower part of the picture with diatoms in the upper portions from plate at CREEK4120.

Figure 18 - (A) Calcite scalehedra with growth faces from precipitate at CREEK3740, (B) incomplete calcite scalehedra from precipitate at CREEK6115, (C) stacked calcite scalehedra from precipitate at CREEK6115, and (D) zoomed view of growth faces and pores on calcite scalehedra from precipitate at CREEK6115 ........................................55

Figure 19 - Detrital quartz grain from plate at CREEK3890

Figure 20 - (A) Overall view of sulfur mineral found on plate from CREEK3890 and (B) closer view of sulfur mineral showing the radial pattern at the center of the crystal. Mineral is likely selenite due to radial nature and sulfur content.....

Figure 21 - (A) midge larvae case from CREEK3740 in May, (B) midge larvae casing from CREEK4120 in May, (C) midge larvae casings from CREEK3740 in August, (D) side view of midge larvae casing.....

Figure 22 - Images of algal growth from May 2011 at (A) CREEK4010 and (B) CREEK4120 ........60

Figure 23 - Calcite Scalehedrons found on precipitation plates from CREEK6150 at $(A)$ at $6.5 X$ magnification and (B) at $40 \mathrm{X}$ magnification

Figure $24-\mathrm{CO}_{2}$ vs temperature which separates the three distinct water types .......................65

Figure 25 - Discharge versus ionic strength for stream samples in May, 2011 versus August, 
Figure 26 - Schematic of meteoric recharge of waters and subsequent reaction with units to produce high TDS thermal springs for Sweet Springs Valley.....

Figure 27 - DOC and DIC plotted against field calculated precipitation rate for samples from August, 2011 and OLDSWT May, 2011 .76

Figure 28 - Temperature data for stream samples (A) CREEK4120, (B) CREEK4010, (C) CREEK3890, and (D) CREEK3470

Figure $\mathbf{2 9}$ - lonic concentrations compared to both calculated (PWP) precipitation rates for calcite and discharge 80

Figure 30 - CarboQC vs. Visual Minteq carbon dioxide measurements compared 83 


\section{List of Tables}

Table 1 - Lithologic descriptions modified from (Virginia Department of Mines Minerals and

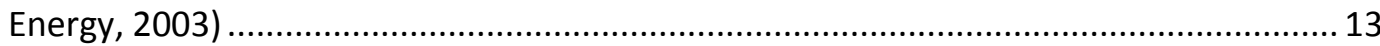

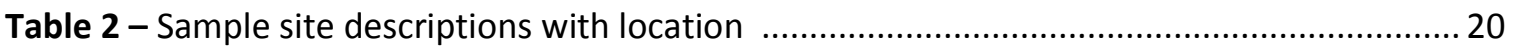

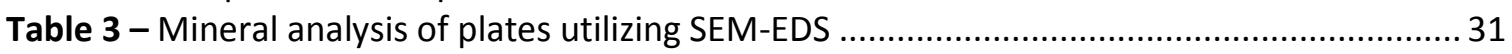

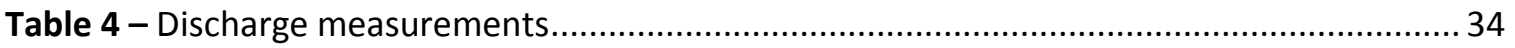

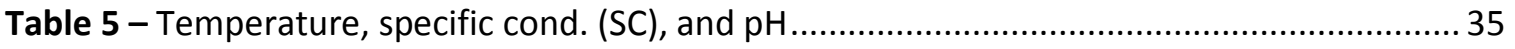

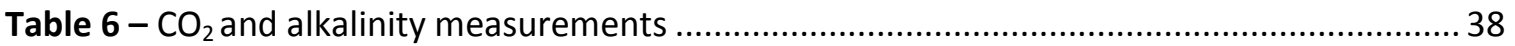

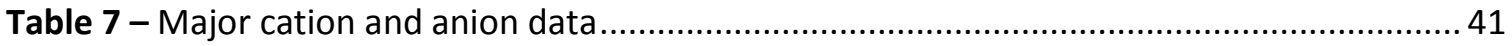

Table 8 - Total organic carbon (TOC), total inorganic carbon (TIC), and total carbon (TC) .......... 43

Table 9 - Comparison of $\mathrm{CO}_{2}$ values as calculated by Visual Minteq and measured by

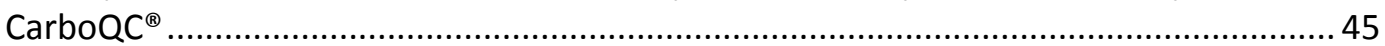

Table 10 - Saturation indices for all sample sites where plates were installed ............................ 46

Table 11 - PWP rates and field-measured rates for calcite precipitation from plate set 1 ..........47

Table 12 - PWP rates and field-measured rates for calcite precipitation from plate set $2 \ldots \ldots \ldots . .49$

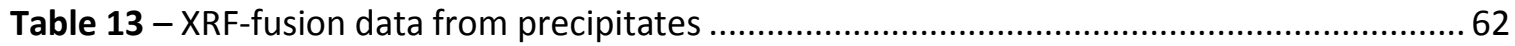

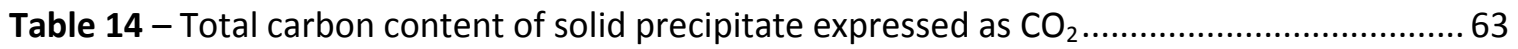

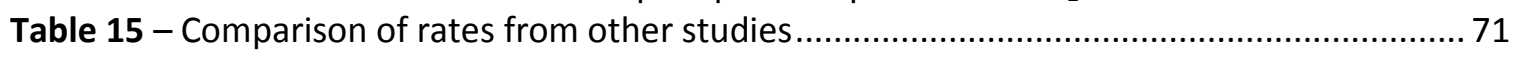

Table 16 - Comparison of SEM-EDS and XRF-fusion for precipitates ........................................ 74 


\section{List of Appendices}

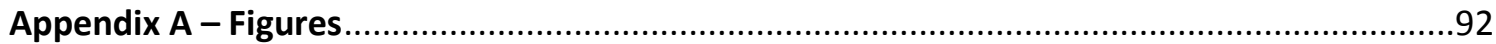

Figure 1A - Lewisburg 30 x 60 Quadrangle (Wilkes, 2002) ........................................93

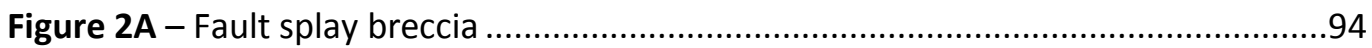

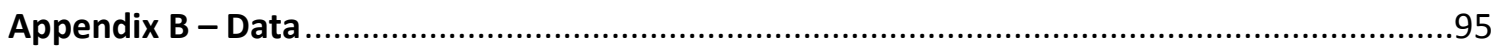

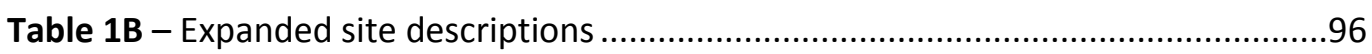

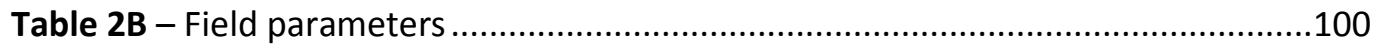

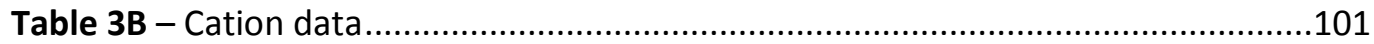

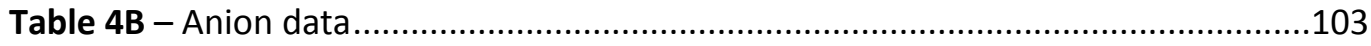

Table 5B - Plate measurements for May-June...............................................................104

Table 6B - Plate measurements for August - September..........................................105

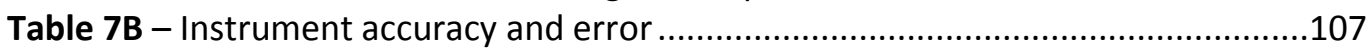

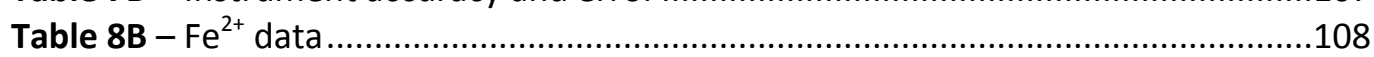

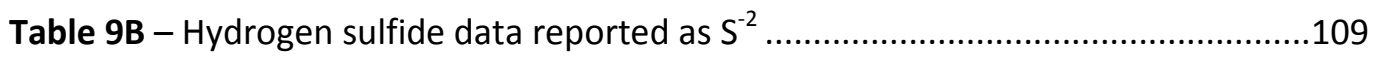

Table 10B - Filter blank data and detection limits ....................................................110

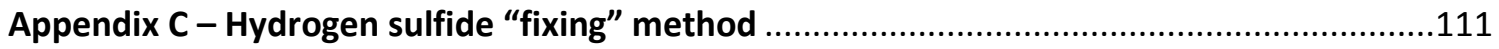




\section{Acronyms and Abbreviations}

DO - Dissolved oxygen

SC - Specific conductivity

$\mathrm{SI}_{\mathrm{x}}$ - Saturation index with respect to mineral $\mathrm{x}$

$\mathbf{Q}$-Discharge

meq - Milliequivalent

NETL - National Energy Technology Laboratory

pCO2 - Partial pressure of carbon dioxide

SEM - Scanning electron microscopy

EDS - Electron dispersive microscopy

PWP - Plummer- Wigley-Parkhurst calcite precipitation rate equation

TIC - Total inorganic carbon

TOC - Total organic carbon

TC - Total Carbon

DIC - Dissolved inorganic carbon

DOC - Dissolved organic carbon

STD - Standard deviation

RSD - Relative standard deviation

XRF-F -X-ray fluorescence fusion

TDS - Total dissolved solids

$\mathbf{n}$ - Number of replicates

WVU - West Virginia University

USGS - United States Geological Survey

CDCS - Carbon dioxide capture and storage

USDOE - United States Department of Energy

ICP-AES - Inductively coupled plasma atomic emission spectroscopy

ICP-MS - Inductively coupled plasma mass spectrometry

IC - Ion chromatography

LOI - Loss on ignition 


\subsection{Introduction}

Anthropogenic $\mathrm{CO}_{2}$ emissions have increased considerably since the beginning of the industrial revolution. Growing concerns over increased atmospheric concentrations of this greenhouse gas have resulted in numerous studies of the environmental impacts of growing emissions and ways to mitigate them (Benson, 2006; Holloway et al., 2006; Intergovernmental Panel on Climate Change, 2005; United States Department of Energy, 2010). One such proposal is to sequester $\mathrm{CO}_{2}$ in geological strata; this process is commonly known as Carbon Sequestration or Carbon Dioxide Capture and Storage (CDCS)(Benson, 2006). As of March 2012, there were 75 large scale programs evaluating various reservoirs and techniques for CDCS throughout the world (Global Carbon Capture and Storage Institute, 2012).

One concern with CDCS is the potential for sudden and catastrophic release of $\mathrm{CO}_{2}$. These concerns are highlighted by documented instances of sudden $\mathrm{CO}_{2}$ emissions causing loss of life at Lake Nyos, Cameroon, where 1,700 individuals died to asphyxia when the lake waters overturned. At Mammoth Mountain, California, tree kills highlight the consequences of sudden and continued release of $\mathrm{CO}_{2}$ due to faults and fractures (Benson, 2006; Holloway et al., 2006; Lewicki et al., 2007). Potential migration along faults has been documented at sites where $\mathrm{CO}_{2}$ is naturally produced, concentrates along fault planes and rises to the surface (Annunziatellis et al., 2008; Bedinger et al., 1979; Farrar et al., 1999; Intergovernmental Panel on Climate Change, 2005; Keating et al., 2010; Lewicki et al., 2007; Miglietta et al., 1993; Rogie et al., 2001; Siegel et al., 2004).

The United States Department of Energy (USDOE) National Energy Technology Laboratory (NETL) is evaluating CDCS and the potential for release of $\mathrm{CO}_{2}$ from sequestration reservoirs. One aspect of this initiative is to utilize natural analog sites, locations where $\mathrm{CO}_{2}$ is naturally released in high concentrations, to evaluate the behavior and detection of $\mathrm{CO}_{2}$. This project involves locating and characterizing springs with elevated $\mathrm{CO}_{2}$, which includes the thermal springs in the west-central portion of Virginia and southern West Virginia.

Springs with elevated $\mathrm{CO}_{2}$ can be found in many places and their properties have been reported in a wide range of studies (Annunziatellis et al., 2008; Bedinger et al., 1979; Cumming, 1997; Dreybrodt et al., 1992; Drysdale et al., 2003; Gradzinski, 2010; Herman et al., 1990; Herman and Lorah, 1988; Hobba et al., 1979; Hubbard and Herman, 1991; Jacboson and Usdowski, 1975; Keating et al., 2010; Lu et al., 2000; Miglietta et al., 1993; Newton et al., 1996; 
Pentecost, 2005; Rogie et al., 2001; Usdowski et al., 1979; Vuataz and Goff, 1986). Three thermal mineral springs with high $\mathrm{CO}_{2}$ and total dissolved solids (TDS) and 2 cold springs were identified in Monroe County, WV and Allegheny County, VA. The thermal mineral springs are associated with travertine deposits in an adjacent stream. The springs and stream provide an opportunity to investigate complex geochemical interactions that occur when $\mathrm{CO}_{2}$-charged waters interact with surface waters to produce travertine.

Travertine is a carbonate mineral deposit, typically comprised of the mineral calcite $\left(\mathrm{CaCO}_{3}\right)$ but also aragonite and dolomite, that forms in continental settings, such as freshwater lakes, springs, and rivers. Precipitation of calcite can be shown by the following reaction:

$$
\mathrm{Ca}^{2+}+2 \mathrm{HCO}_{3}^{-} \longrightarrow \mathrm{CaCO}_{3}(\mathrm{~s})+\mathrm{H}_{2} \mathrm{O}+\mathrm{CO}_{2} \text { (g) [Eq. 1] }
$$

The loss of $\mathrm{CO}_{2}$ increases the saturation index relative to $\mathrm{CaCO}_{3}\left(\mathrm{SI}_{\mathrm{CALCITE}}\right)$. A saturation index $>0$ indicates that a solution is supersaturated with respect to the mineral and that precipitation can occur; inversely, a saturation index $<0$ corresponds with undersaturation and dissolution.

Travertine-depositing waters have been studied extensively, typically focused on quantifying the reactions and rates of deposition or morphology and bulk physical change (Chafetz et al., 1991; Chou et al., 1989; Dreybrodt et al., 1992; Drysdale et al., 2003; Gradzinski, 2010; Herman et al., 1990; Hubbard and Herman, 1991; Hubbard et al., 1990; Kawai et al., 2009; Lorah and Herman, 1990; Lu et al., 2000; Takano et al., 1980; Zaihua et al., 1995; Zhang et al., 2001). The studies focused on reactions and rates of deposition concluded that $\mathrm{CO}_{2}$ degassing is the primary mechanism controlling rates and localities of travertine deposits (Dreybrodt et al., 1992; Gradzinski, 2010; Hubbard and Herman, 1991; Kawai et al., 2009; Lorah and Herman, 1988; Lorah and Herman, 1990; Lu et al., 2000).

While the degassing of $\mathrm{CO}_{2}$ is considered to be the primary rate controlling variable in determining the precipitation rate of travertine, other variables that influence precipitation rate should be considered (Lorah and Herman, 1990; Takano et al., 1980). Variables that influence precipitation rate estimation include: major ionic species other than $\mathrm{Ca}^{2+}$, dissolved organic carbon (DOC), biota, mineral co-precipitation and flow dynamics. Laboratory experiments have shown that $\mathrm{SO}_{4}{ }^{2-}, \mathrm{Mg}^{2+}$, phosphates, iron, and $\mathrm{DOC}$ can slow the precipitation rate of $\mathrm{CaCO}_{3}$ (Buhmann and Dreybrodt, 1987; Inskeep and Bloom, 1986; Lebron and Suarez, 1996; Meyer, 1984; Reddy, 1986). Biota have been found to both enhance and degrade the growth of $\mathrm{CaCO}_{3}$ from solution (Gradzinski, 2010; Lu et al., 2000). Flow dynamics, relating to the diffuse boundary layer, were shown to be an important consideration when evaluating precipitation 
rates (Dreybrodt et al., 1992; Zaihua et al., 1995). Evaluating these variables will help to account for factors other than $\mathrm{CO}_{2}$ outgassing that affect measurement of travertine precipitation rates. 


\subsection{Statement of purpose}

The goal of this study was to compare theoretical calcite precipitation rates (PWP rates) with field-measured precipitation rates while considering potential inhibitors of precipitation. In order to achieve these goals, the following research questions were considered:

- Does the calcite (travertine) precipitation rate approximate the theoretical maximum provided by rate equations?

- Are minerals other than $\mathrm{CaCO}_{3}$ present in appreciable quantities?

- Are there significant concentrations of ions other than $\mathrm{Ca}^{2+}$ in the travertine precipitate?

- Does the presence and degree of colonization by organisms correlate with differences in observed mineral precipitation rate?

- What is the concentration of dissolved organic carbon in the waters and does it correlate with a deviation in precipitation rate with respect to theoretical rate equations? 


\subsection{Literature review}

\subsection{Thermal mineral springs and $\mathrm{CO}_{2}$}

Thermal springs in the Appalachians, specifically in Virginia and West Virginia, have been studied with regards to their origin and chemistry since the turn of the $20^{\text {th }}$ century (Collins et al., 1930; Goggin, 1991; Herman and Lorah, 1986; Hobba et al., 1979; McColloch and Price, 1986; Perry et al., 1979; Rader and Thomas M. Gathright, 1984; Reeves, 1932). The source of heat and depth of circulation has been hypothesized to be a product of water transiting along thrust faults that interact with a shallow plutonic intrusion (Dennison and Johnson, 1971). However, most researchers support the hypothesis that the thermal springs are products of deeply circulating meteoric water that is heated via a normal geothermal gradient and rises along deeply bedded carbonates on the flanks of anticlines until it escapes along fractures and faults (Hobba et al., 1979; Hubbard et al., 1990; Lorah and Herman, 1990; Rader and Thomas M. Gathright, 1984; Reeves, 1932). Borehole studies have supported the meteoric circulation hypothesis via temperature measurements at depth that confirm sufficient thermal gradients to heat the waters in question without the need for a pluton (Perry et al., 1979).

The thermal springs are often associated with elevated $\mathrm{CO}_{2}$ and the sources of $\mathrm{CO}_{2}$ are speculative, with theories ranging from geochemical equilibrium of waters with aquifer carbonates (Hobba et al., 1979) to plutonically induced mantle $\mathrm{CO}_{2}$ migration (Dennison and Johnson, 1971). Goldscheider et al. (2010) analyzed similar thermal springs in Europe and found that the waters were associated with meteoric waters with prolonged residence times in deep karst with acid producing minerals; these minerals then dissolved carbonates and produced $\mathrm{CO}_{2}$. The springs, like those in the Appalachians, are associated with faults and fractures that act as conduits for fast transmission to the surface.

\subsection{Travertine genesis}

Travertine is produced when the ( $\mathrm{SI}_{\text {CALCITE}}$ ) reaches a magnitude of 5-10 (Dreybrodt and Buhmann, 1991; Herman and Lorah, 1987; Lorah and Herman, 1990; Zhang et al., 2001). The $\mathrm{SI}_{\text {CALCIEE }}$ is described by the following:

$$
\mathrm{SI}_{\mathrm{CALCITE}}=\frac{\left(\alpha \mathrm{Ca}^{2+}\right)\left(\alpha \mathrm{CO}_{3}^{2-}\right)}{K_{\text {CALCITE }}}
$$


where $\mathrm{K}_{\text {CALCITE }}$ is the temperature dependent equilibrium solubility product for $\mathrm{CaCO}_{3}$ and $\alpha$ represents the respective activities of $\mathrm{Ca}^{2+}$ and $\mathrm{CO}_{3}{ }^{2-}$. The $\mathrm{SI}_{\text {CALCITE }}$ increases with outgassing of $\mathrm{CO}_{2}$ as described in the following partial reaction from equation 1 :

$$
2 \mathrm{HCO}_{3}^{-} \longrightarrow \mathrm{H}_{2} \mathrm{CO}_{3}{ }^{*}+\mathrm{CO}_{3}^{-2}
$$

where bicarbonate $\left(\mathrm{HCO}_{3}{ }^{-}\right)$forms $\mathrm{H}_{2} \mathrm{CO}_{3}{ }^{*}$, which is equivalent to the concentration of aqueous $\mathrm{CO}_{2}$ in water (Stumm and Morgan, 1996), and the carbonate ion $\mathrm{CO}_{3}^{-2}$. The $\mathrm{CO}_{3}^{-2}$ is then free to bond with dissolved $\mathrm{Ca}^{2+}$ and form the mineral calcite. As a result, deposition is greatest in turbulent zones, typically rapids or falls, which allow more of the water surface area to be exposed to the atmosphere; this exposure facilities a greater exchange of $\mathrm{CO}_{2}$ (Chafetz et al., 1991; Dreybrodt and Buhmann, 1991; Herman and Lorah, 1988; Hubbard and Herman, 1991; Hubbard et al., 1990; Kawai et al., 2009; Lu et al., 2000; Pentecost, 2005; Zaihua et al., 1995; Zhang et al., 2001).

Tufa and travertine are terms often used interchangeably in much of the literature to describe the phenomena of precipitation of $\mathrm{CaCO}_{3}$ in continental settings (Pentecost, 2005). However, delineations exist based on temperature in which tufa are considered to form in ambient temperature conditions and travertine to form in thermal conditions, which are waters consistently above ambient air temperature and independent of seasonality. In this study, the mineral waters originate in thermal springs but $\mathrm{CaCO}_{3}$ precipitation occurs in ambient temperature waters of Sweet Springs Creek. In order to stay consistent, a working definition of travertine was developed for this thesis, such that travertine is defined as "A carbonate deposited in or adjacent to thermal spring waters $\left(>15^{\circ} \mathrm{C}\right)$ in a continental setting."

\subsection{Travertine precipitation studies}

\subsubsection{Theoretical and observed precipitation rates}

Lorah and Herman $(1988 ; 1990)$ investigated the field-measured rate of travertine precipitation versus theoretical calculations resulting from the Plummer-Wigley-Parkhurst (PWP) calcite precipitation rate equation (Plummer et al., 1978). Their study used Iceland spar seed crystals suspended in the water column via a cage structure as a substrate for the growth of $\mathrm{CaCO}_{3}$ in Falling Spring Creek, VA. The mass of the crystals and surface area was measured before the experiment began and the mass was measured again after a set period of time; all mass change was interpreted as $\mathrm{CaCO}_{3}$ growth. They found that the PWP rates were consistently 1-2 orders of magnitude higher than the rates found by in-situ mass change of the 
Iceland spar seed crystals. The authors noted that biologic activity and $\mathrm{Mg}^{2+}$ were possible sources of error, but found biologic activity was not important to the removal of carbonate and that $\mathrm{Mg}^{2+}: \mathrm{Ca}^{2+}$ ratios were less than 1, which indicates no competition for nucleation sites as described by Usdowski et al. (1979). The findings suggested that the kinetic inhibition of $\mathrm{CaCO}_{3}$ precipitation was controlled by the rate of $\mathrm{CO}_{2}$ outgassing, much as described by Plummer et al. (1978). The small variation in observed and calculated rates confirmed the validity of utilizing the PWP rate as a proxy for precipitation rates, which previously had not been attempted.

Dreybrodt et al. (1992) expanded on the work performed by Herman and Lorah (1988), but used limestone plates suspended in the water column as the mineral precipitation substrate instead of Iceland spar seed crystals. $\mathrm{CO}_{2}$ outgassing was reaffirmed as the primary controlling factor in precipitation and the authors found similar deviations between calculated and measured rates to Herman and Lorah (1990), where the PWP rate was 1 order-of-magnitude greater than the field-measured rates. Dreybrodt et al. (1992) found that they could mitigate the difference between measured and PWP calculated rates by accounting for the diffuse boundary layer. In order to account for this layer, the authors suspended gypsum plates in the water column; gypsum dissolves entirely by diffusion and by measuring mass loss of gypsum the diffusion double layer was estimated (Dreybrodt and Buhmann, 1991). The correction factor due to the diffuse boundary layer was approximately 10 times, which effectively negated the difference between measured and observed rates. Zaihua et al. (1995) used marble plates in identical fashion to Dreybrodt et al. (1992) and found similar results in that the deviations could be mitigated by accounting for the diffuse double layer.

\subsubsection{Characterization of travertine precipitation}

Chafetz and Folk (1983) analyzed travertines in central Italy and the western United States with regards to morphology and biota. Their research did not quantify rates of deposition, but found that bacterially mediated precipitation of calcite accounted for $90 \%$ of the grains in lake deposits and that most travertines are calcite. Their analysis was one of the first to link the inorganic travertine precipitation with organic processes in a quantitative method and present evidence of bacterial mediation in ancient deposits.

Lu et al. (2000) performed similar experiments to the Herman and Lorah (1990), but they used glass plates fastened to stakes anchored in the stream bed as a substrate for precipitation and precipitation rates were not calculated. The study incorporated measurements of dissolved inorganic carbon (DIC), $\mathrm{Ca}^{2+}$, and geomorphological character of the 
stream to evaluate where DIC was being lost from the aqueous phase and deposited as travertine along Huanglong stream, China. Travertine precipitation was found to be the most prevalent on those plates near dams and turbulent areas along the stream. The authors found up to a $40 \%$ decrease in mass of precipitate when algae was present and signs of etching and dissolution when diatoms were present suggesting biota were interfering with precipitation. They also found a polymorph of calcite, vaterite, present at one site.

Gradzinksi (2010) used travertine plates and copper plates attached to the stream as substrate to evaluate relative travertine precipitation. Copper plates were utilized as a control on biotic participation in travertine formation. The results were not compared to any theoretical maximum and were considered semi-quantitative due to the difference in growth on the two different plate surfaces as well as the problem of surface area change as precipitate accumulated. The author concluded that biologic media were not crucial to the growth of travertine, but that the travertine substrate had significantly more precipitate than copper substrate indicating biologic enhancement of precipitation.

\subsection{Calcite precipitation inhibition}

In general, calcite crystals grow by the bonding of free $\mathrm{Ca}^{2+}$ ions with the $\mathrm{CO}_{3}{ }^{-2}$ in solution, which form rhombohedral "units" that stack symmetrically (Aquilano et al., 2003; Reddy, 1983). These units must first nucleate onto a substrate and subsequently onto each other, which requires overcoming kinetic barriers; in effect, turbulence and a critical SI CALCITE. If growth sites are kinetically favorable to growth, then precipitation will occur, however, if the state of the system is more kinetically favorable to other species or substances in solution to form on the substrate, then calcite will not precipitate.

Ions other than $\mathrm{Ca}^{2+}$ are known to inhibit the precipitation and dissolution of calcium carbonate and include: $\mathrm{Mg}^{2+}, \mathrm{SO}_{4}{ }^{2-}$, iron species, and phosphates (Busenberg and Plummer, 1985; Meyer, 1984; Reddy, 1986; Reddy et al., 1981; Takano et al., 1980). The inhibitory characteristics of any ion are attributed to their effect on ionic strength, ability to substitute in the crystal lattice for $\mathrm{Ca}^{2+}$ or $\mathrm{CO}_{3}{ }^{2-}$, and their ability to block active growth sites. Meyer (1984) conducted experiments on all of the aforementioned inhibitors and concluded that while all ions had the ability to inhibit calcite precipitation, the amount that each reduced the growth rate varied by four orders of magnitude. Reddy $(1977 ; 1986)$ found, much like Meyer (1984), that $\mathrm{Mg}^{2+}$ and phosphates were effective inhibitors. Phosphate disrupted nucleation at the calcite surface, and $\mathrm{Mg}^{2+}$ did as well, when the solution surpassed a ratio of 1:1 with respect to 
$\mathrm{Mg}^{2+}: \mathrm{Ca}^{2+}$. Busenberg and Plummer (1985) found that the activity of $\mathrm{SO}_{4}{ }^{2-}$ was critical in the effectiveness of inhibition, suggesting inhibition variability associated with ionic strength. While the inhibitory characteristics indicate the relative effectiveness per mol of additive, the relative abundance of each in natural waters should be considered; $\mathrm{SO}_{4}{ }^{2-}$ is one of the most common ions in natural waters and is likely to have a greater effect than is presented by Meyer (1984).

Dissolved organic carbon (DOC), more specifically organic ligands, has been shown to block active nucleation sites in $\mathrm{CaCO}_{3}$ (Inskeep and Bloom, 1986; Lebron and Suarez, 1996; Reddy, 1977). Increasing DOC resulted in decreased precipitation rates in all evaluations, however, the relationship is not linear as shown by Lebron and Suarez (1996). They used waters with $\mathrm{pH}>7.5$ and waters with a $\mathrm{Ca}: \mathrm{HCO}_{3}$ molar ratio of $1: 2$ and found that with $0.15 \mathrm{mM} \mathrm{DOC}$ the $\mathrm{CaCO}_{3}$ precipitation would remain constant and at $0.3 \mathrm{mM} \mathrm{DOC}$ it would cease. At $0.15 \mathrm{mM}$ DOC particle sizes did not increase over time as would normally happen during active growth. However, at $0.02 \mathrm{mM} \mathrm{DOC}$ the rate of growth was not reduced which illustrates the presence of thresholds for inhibition. Their experiments also included nucleation in the absence of a substrate and found initial nucleation slowed with increasing DOC concentration.

Chafetz and Folk (1983) and Gradzinski (2010) have differing views from Lu et al. (2000) on the effects of organisms on the precipitation of travertine. Chafetz and Folk (1983) concluded that the bacteria mediated growth of travertine in lake sediments, but their research did not evaluate algae or diatoms and was conducted on lake fill travertine. Gradzinski (2010) found that the presence of algae and microorganisms resulted in an increase in the abundance of travertine on travertine substrates; this conclusion was drawn relative to copper plates which had no organisms and significantly less precipitate. Lu et al. (2000) found that the presence of diatoms and algae coincided with less travertine precipitation on glass plates and found evidence of dissolution and etching where the organisms were present. These conflicting views are the product of varying experimental conditions and may not represent true variability associated with the presence of microorganisms. 


\subsection{Site description}

\subsection{Regional setting and geology}

The research area is located in the central Appalachian Mountains of the eastern United States (Figure 1). The bounds of the study were chosen with respect to the Sweet Springs Creek Watershed, and the beginning and end of Sweet Springs Creek. The delineated area only accounts for a portion of the watershed and comprises an area of approximately eight $\mathrm{km}^{2}$. The western side of the area is marked by the Allegheny Front, which is the transition to the Allegheny Plateau physiographic province (Orndorff et al., 1994).

The regional stratigraphy is comprised of intervals of siliclastics, carbonates, and organic-rich shales (Figure 2). Units were initially deposited in a shallow epicontinental basin which continually deepened throughout the Cambrian and into the late Ordovician. The Taconic Orogeny, $\sim 450$ million years ago (MYA), produced intense uplift and faulting that deformed the entire region; this period was also the transition to siliclastics and intermittent evaporites as the basin shallowed (Bailey, 2000; Orndorff et al., 1994). Erosion of the Taconic Mountains resulted in an influx of sediments into the basin during the Silurian and early Devonian. The Acadian Orogeny during the early to middle Devonian rejuvenated deposition and resulted in coarser units being deposited. Deposition continued, but slowed until the middle Carboniferous, when the Alleghenian Orogeny occurred. This event defined much of the structural character seen today and resulted in crustal shortening on the order of $200 \mathrm{~km}$. Compressional stress varied north to south, causing the northern portions to be highly folded and the southern portions to be more faulted (Sherwood, 1977).

\subsection{Local geology and field reconnaissance}

The 5 springs occur predominantly in Ordovician carbonates along the axis of an anticline and in Siluro-Devonian limestones on the flanks of anticlines (Rader and Thomas M. Gathright, 1984). Most of the lithologic units do not have surface exposures and actual contacts are hard to distinguish. Old Sweet Spring (OLDSWT) occurs in Ordovician units consisting of the Reedsville Shale, Dolly Ridge Limestone, and the Eggleston Formation (Table 1). The character of these units is not readily visible due to weathering and infill. Sweet Chalybeate (CHAL) and Sweet Chalybeate 2 (CHAL2.0C,M) springs issue from the Ordovician-aged Beekmantown Formation, which is a thickly-bedded dolostone with cherty bedding near the top (Wilkes, 2002). Cesspool Cave (CESSPE) likely emerges from the Devonian aged Millsboro shale, which may also include portions of the Needmore Formation. The contact is not distinct due to weathering and 

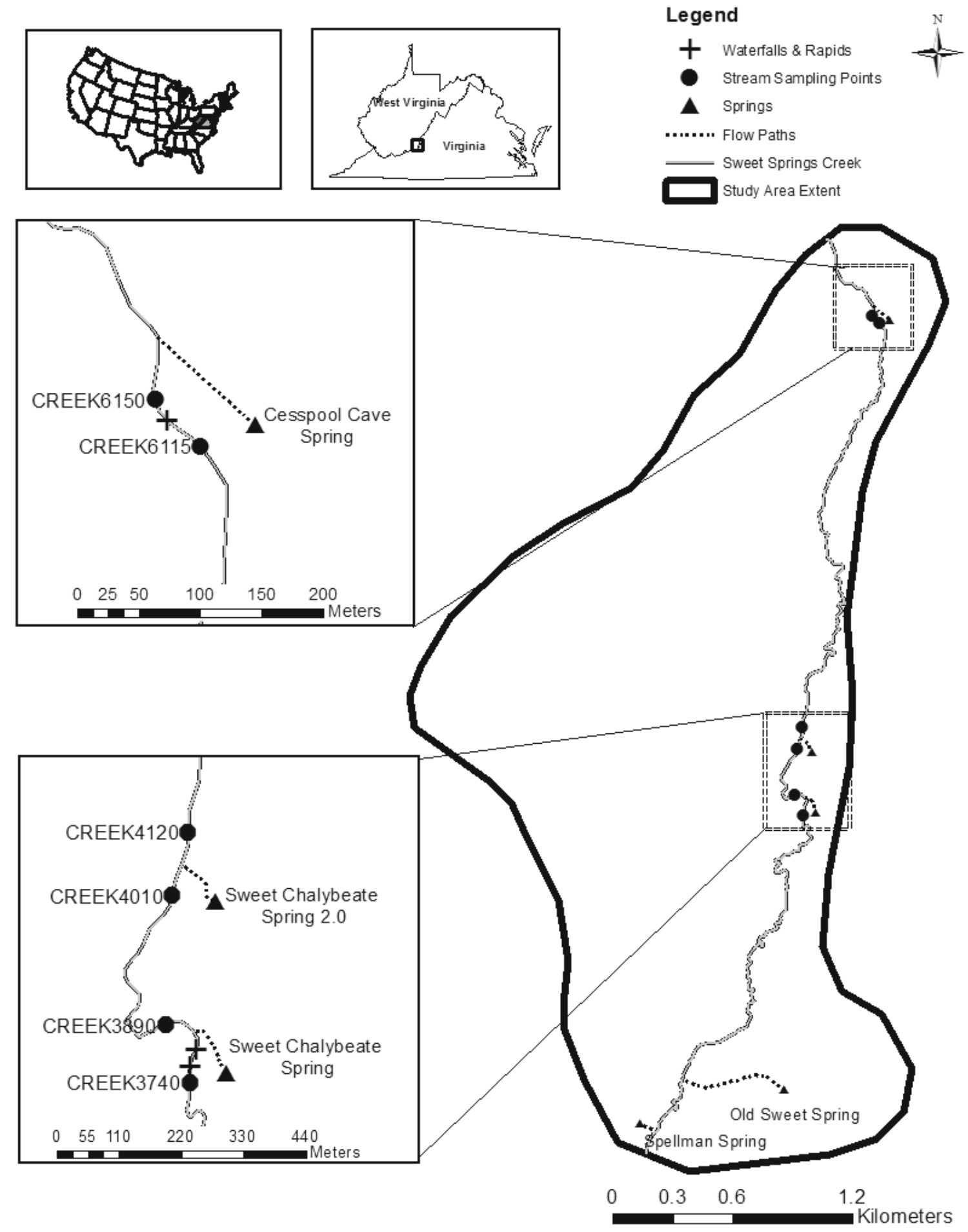

Figure 1 - Overview of the Sweet Springs Valley study area in West Virginia and Virginia. Figure provides study area locations relative to the United States. Data obtained from the USGS Geospatial Gateway and the NRCS Geospatial Data Gateway, 2010-2011. 

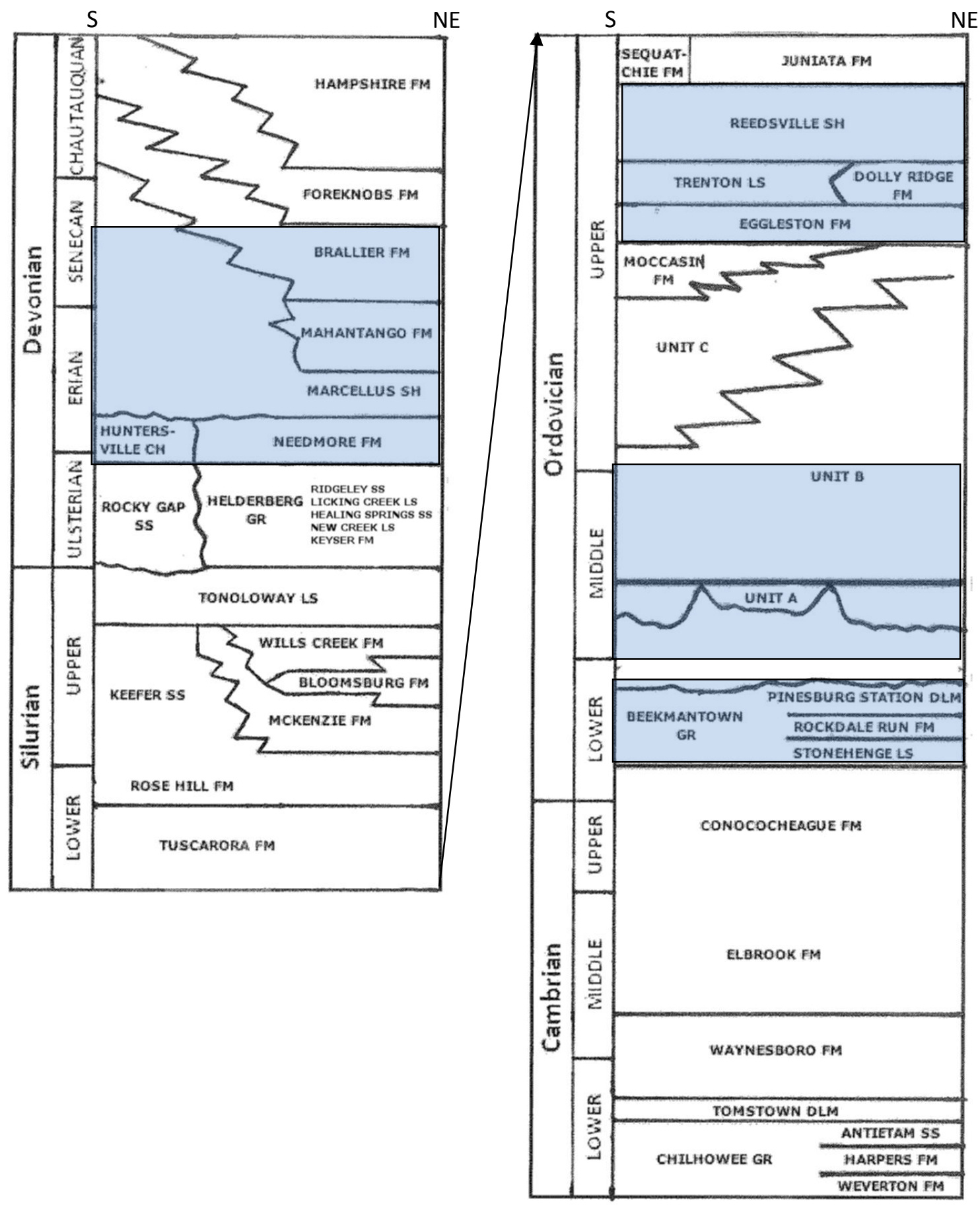

Figure 2 - Stratigraphic section for Valley and Ridge Province. Highlighted units represent those from which springs emerge. Modified from (Wilkes, 2002) 
Table 1 - Lithologic descriptions modified from (Virginia Department of Mines Minerals and Energy, 2003)

\begin{tabular}{|c|c|c|c|}
\hline Age & & t/Formation & Description \\
\hline 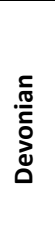 & $\begin{array}{l}\text { Brallie } \\
\text { Millsb } \\
\text { Tioga } \\
\text { Needn }\end{array}$ & $\begin{array}{l}\text { ormation } \\
\text { Shale } \\
\text { erval } \\
\text { e Formation }\end{array}$ & $\begin{array}{l}\text { Siltstone with interbeds of shale and sandstone, olive gray, micaceous, and } \\
\text { fossiliferous } \\
\text { Black fissle shale with basal limestone beds } \\
\text { Gray silty shale (bentonite beds) } \\
\text { Olive gray shale with calcareous mudstone; fossiliferous }\end{array}$ \\
\hline \multirow{3}{*}{ 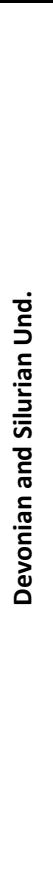 } & Ridgel & Sandstone & Gray calcareously cemented sandstone with fine-coarse grains \\
\hline & $\begin{array}{l}\frac{0}{7} \\
\frac{0}{0} \\
\text { o. } \\
\frac{0}{0} \\
\frac{0}{0} \\
\frac{0}{0} \\
\frac{0}{1}\end{array}$ & $\begin{array}{l}\text { Licking Creek } \\
\text { Limestone } \\
\text { Healing Springs } \\
\text { Sandstone } \\
\text { New Creek } \\
\text { Limestone } \\
\text { Keyser } \\
\text { Formation } \\
\text { Clifton Forge } \\
\text { Sandstone } \\
\text { Tonoloway } \\
\text { Limestone }\end{array}$ & $\begin{array}{l}\text { Gray arenaceous limestone with white chert } \\
\text { Medium grained calcereously cemented sandstone with crossbedding } \\
\text { Gray to pink coarse grained limestone with crinoids } \\
\text { Coarse-grained, nodular, arenaceous limestone } \\
\text { Quartz arenite ledge-former } \\
\text { Fine grained, grey, limestone that is thinly bedded; upper section is thickly } \\
\text { bedded, coarse grained, turbidites }\end{array}$ \\
\hline & 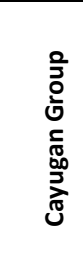 & $\begin{array}{l}\text { Wills Creek } \\
\text { Formation } \\
\text { Williamsport } \\
\text { Sandstone } \\
\text { McKenzie } \\
\text { Formation }\end{array}$ & $\begin{array}{l}\text { Silty shale that weathers yellow } \\
\text { Indurated, greenish-gray sandstone with siltstone interbeds } \\
\text { Calcareous, cross-bedded sandstone,interbedded limestone }\end{array}$ \\
\hline$\frac{\frac{c}{2}}{\frac{\pi}{2}}$ & $\begin{array}{l}\text { Rose } \\
\text { Tuscar }\end{array}$ & Formation & $\begin{array}{l}\text { White to light gray sandstone, medium to coarse grains, quartzite in places, } \\
\text { massive ledge former } \\
\text { Maroon, medium-grained, hematitic sandstone, shale and silstone } \\
\text { interbeds } \\
\text { White to light gray sandstone with medium to coarse grains, quartzitic, } \\
\text { white pebble conglomerate in lower part of unit }\end{array}$ \\
\hline $\begin{array}{l}\frac{c}{\pi} \\
\frac{\pi}{3} \\
0 \\
0 \\
0 \\
0\end{array}$ & $\begin{array}{l}\text { Juniat } \\
\text { Reeds } \\
\text { Dolly }\end{array}$ & $\begin{array}{l}\text { ormation } \\
\text { e Shale } \\
\text { ge Formation } \\
\text { ne Formation } \\
\text { rdovician Und. }\end{array}$ & $\begin{array}{l}\text { Sandstone, shale, and mudstone interbeds, red to olive gray } \\
\text { Calcareous shale and siltstone, yellow to gray } \\
\text { Gray limestone with thin beds, fine-grained, interbedded with claystone, } \\
\text { limestone, and shale } \\
\text { Mudstone and siltstone, green to yellow; olive gray limestone, medium } \\
\text { grained, thin bedded } \\
\text { Limestone, gray with black chert; limestone, coarse-grained, thick-bedded, } \\
\text { knobby-weathering; limestone, gray to red fine grained; limestone, cherty } \\
\text { with calcareous shale } \\
\text { Gray dolostone, thick bedded, fine-grained, butcher block jointing, black } \\
\text { bedded chert, and beds of white chert near the top }\end{array}$ \\
\hline
\end{tabular}


travertine deposition over the site and therefore a definitive lithologic origin cannot be determined. Spellman spring (SPELM) is a near surface karst spring that issues from the same Ordovician units as OLDSWT.

The main branch of the St. Clair Thrust Fault, which is the largest fault exposed in the Appalachian mountains, strikes through the middle of the Sweet Springs Valley and terminates approximately $15 \mathrm{~km}$ to the northeast (Sturms, 2008). The fault was formed exclusively during the Alleghenian Orogeny and defines the boundary of the Allegheny Structural Front, which separates the Valley and Ridge province from the Appalachian Plateau province. A fault splay branches from the main fault and runs parallel with the northwestern trending ridge that bounds the study area. The St. Clair thrust fault and splay effectively exhume and stack the Silurian and Devonian units in the middle of the valley (Figure 3).

\subsection{Detailed description of Sweet Springs Creek}

The section of Sweet Springs Creek under investigation has an average gradient of $5.1 \mathrm{~m}$ $\mathrm{km}^{-1}$. This value is inflated due to the abrupt elevation changes associated with the rapids and waterfalls that punctuate the section. If the reaches with waterfalls and rapids are excluded, the average gradient is $2.1 \mathrm{~m} \mathrm{~km}^{-1}$.

The stream varies in depth and width, ranging from $0.3 \mathrm{~m}$ to $>1 \mathrm{~m}$ and $2 \mathrm{~m}$ to $10 \mathrm{~m}$, respectively. Bedload materials range in size and distribution throughout the reach, mostly controlled by anthropogenic influence. In the downstream reaches, which are close to Highway 311 , which runs the length of the valley, and to homes, there are gravels, cobbles, and even boulders armoring the channel. Upstream, the bedload is less coarse and is interspersed with fine grained sediments. Near rapids and falls, there is typically extensive travertine, and there is little bedload since the travertine is accretionary and limits mobility of the bedload.

Travertine deposits are located at two primary locations along the stream reach, between sampling sites CREEK3740 and CREEK 3890 and between CREEK6115 and CREEK6150 (Figure 4). Active travertine deposition occurs 5-10 $\mathrm{m}$ before both upstream sampling points and more extensively after the sampling points in the falls and rapids. Travertine deposition occurs at the base of the rapids and falls as well, but does not extend more than $5 \mathrm{~m}$ past the termination of these turbulent zones. The thickness of the deposits is not known; however the Sawmill Falls escarpment that precedes Creek 6115 and initiates the waterfall is at least $10 \mathrm{~m}$ thick as observed from exposed section (Figure 5). 


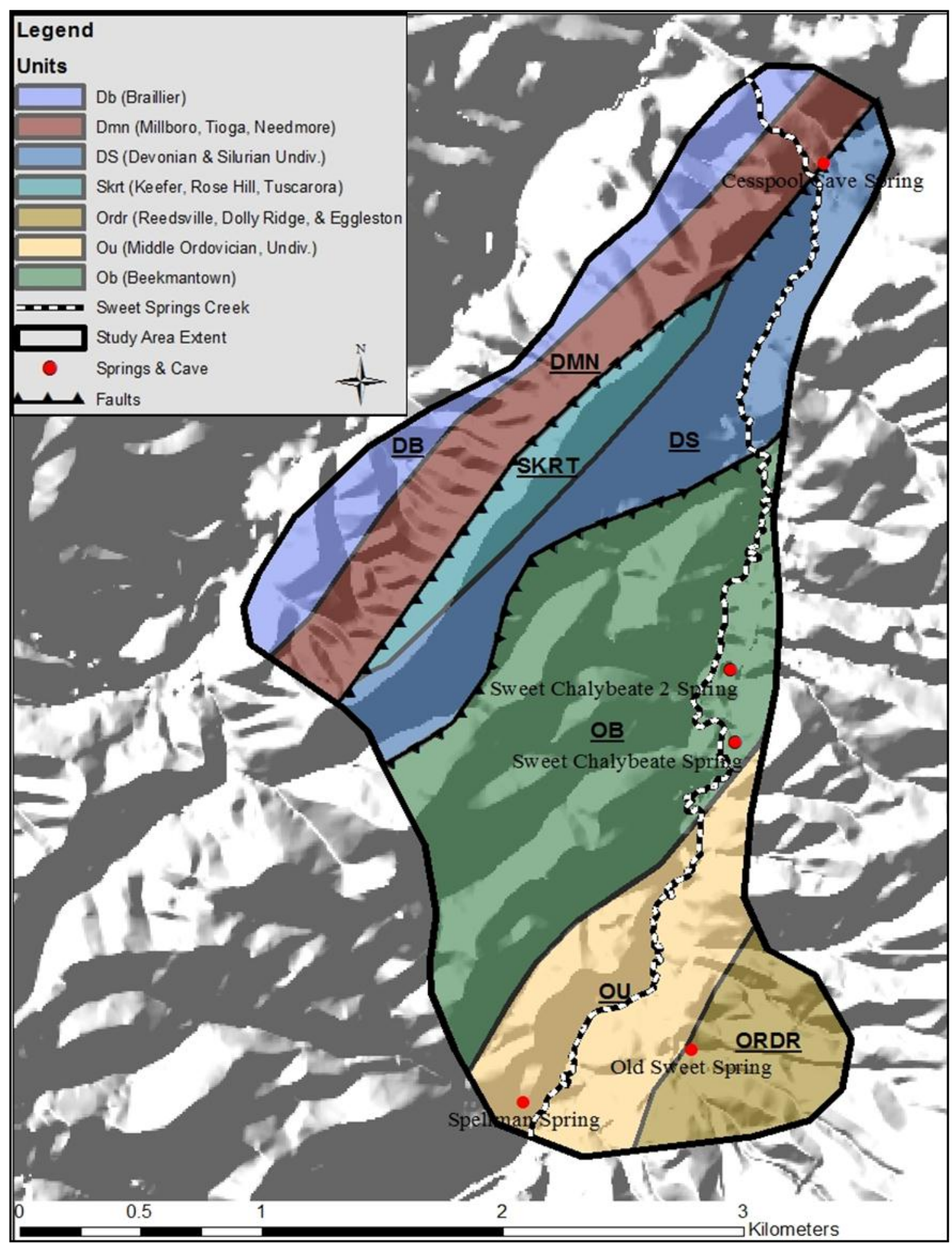

Figure 3 - Geologic map overlying elevation for the study area. Elevation data obtained from the NRCS Geospatial Data Gateway, 2011. 

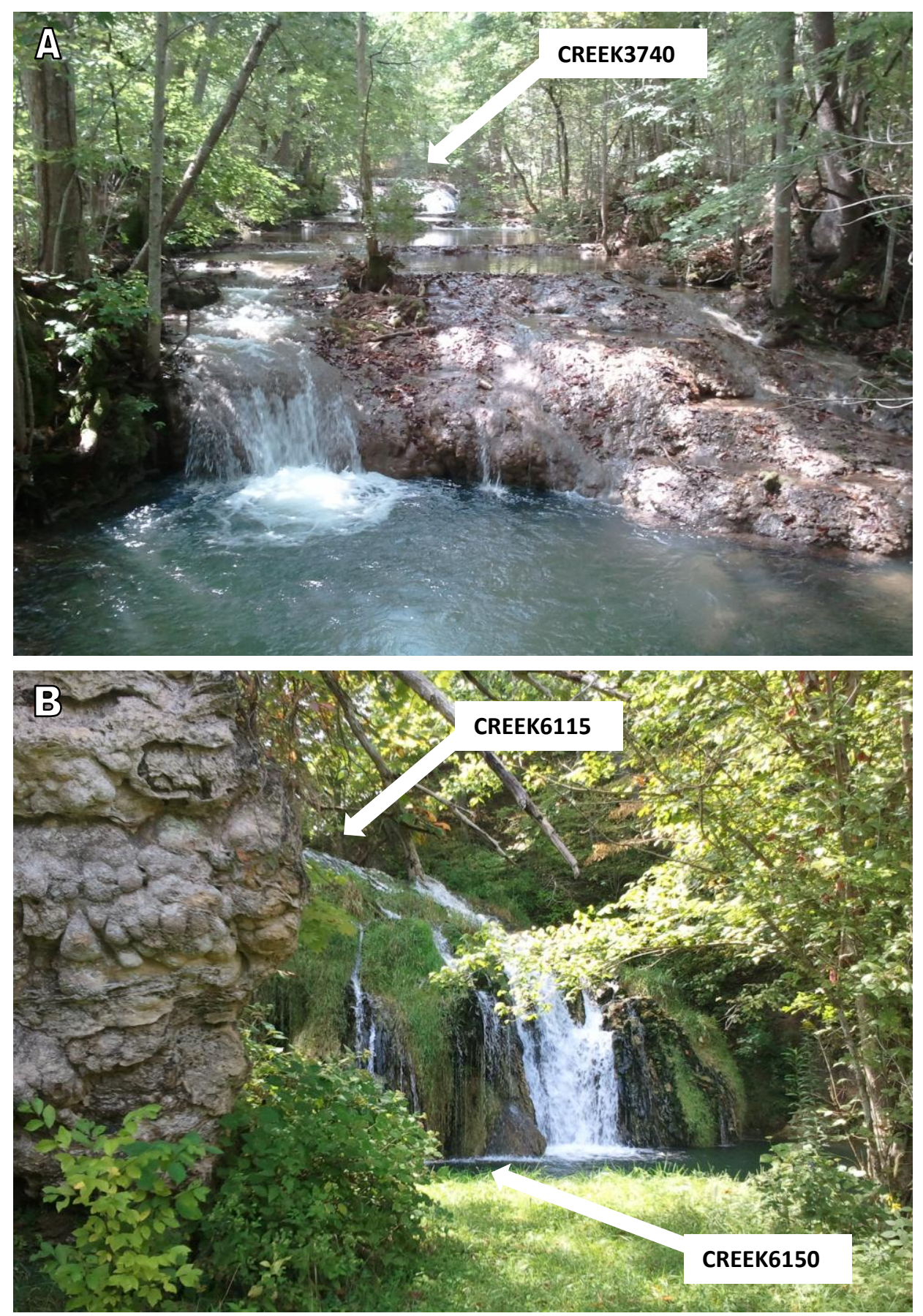

Figure 4 - (A) Image showing the travertine rapids after CREEK3740, (B) image showing the Sawmill Falls escarpment in conjunction with the Sawmill Falls that lie between CREEK6115 and CREEK6150. 


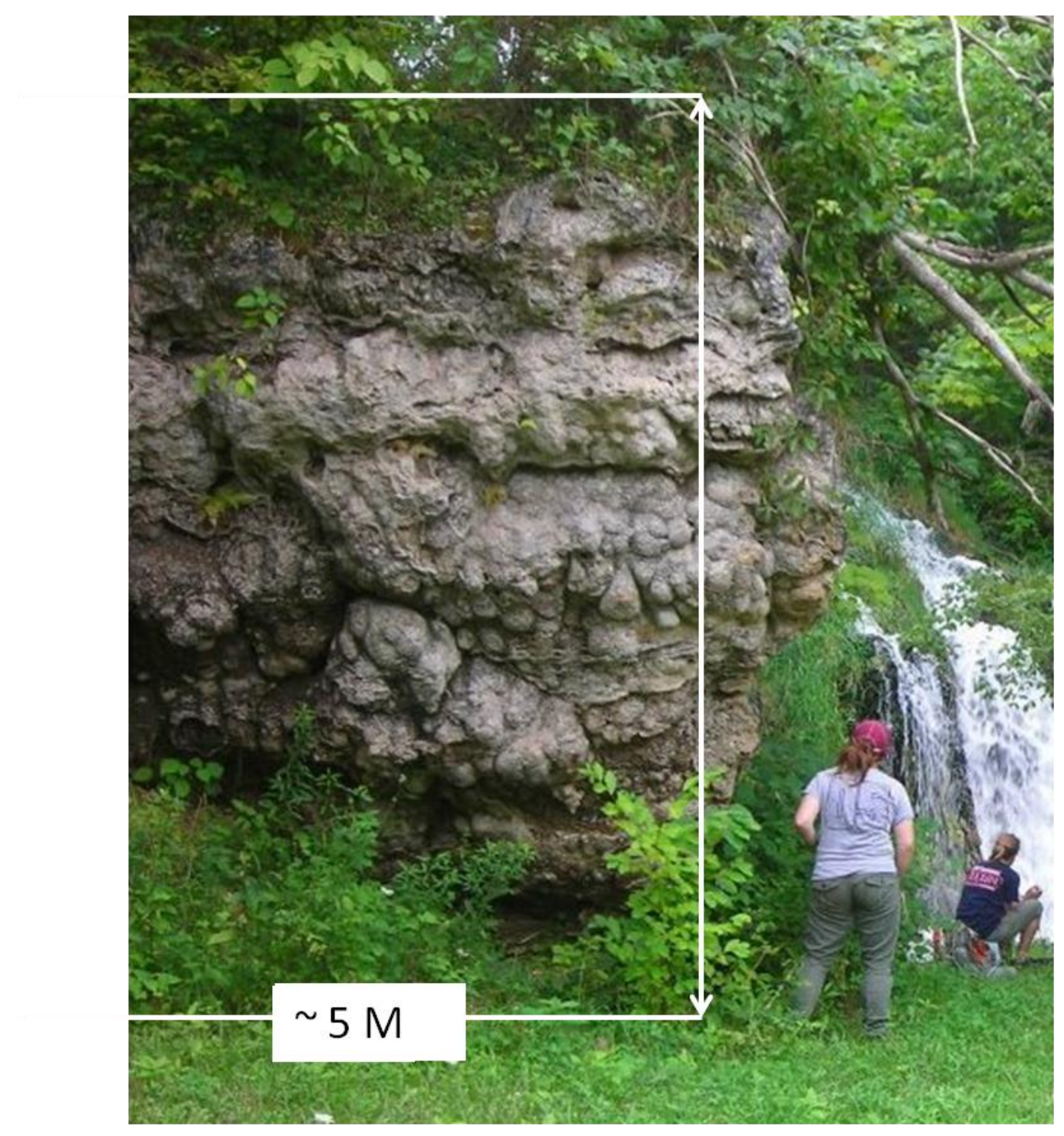

Figure 5 - Outcrop of travertine terrace at the Sawmill Falls Escarpment. Height of standing individual is approximately $1.6 \mathrm{~m}$ giving the terrace a height of approximately $5 \mathrm{~m}$. It is one of at least two terraces of similar dimension that comprise the escarpment. 


\subsection{Spring descriptions}

All of the springs, with the exception of SPELM, flow into Sweet Springs Creek from elevations above the creek and between sampling sites (Figure 6). SPELM is used as the boundary of the study area and emerges into a pool at creek level that discharges into the creek (Table 2). All other springs discharge into pools that have outlets at higher elevations than Sweet Springs Creek; the pool for CESSPE is inside the cave and the outlet into the creek is downstream of the study area (Figure 7). Creek sampling points were located before and after all spring inputs and/or rapids and falls.

\subsection{History of the Sweet Springs Valley}

OLDSWT and CHAL springs were both transformed into resorts in the $18^{\text {th }}$ and $19^{\text {th }}$ century by entrepreneurs seeking to exploit the springs for their therapeutic properties (McColloch and Price, 1986). The main building at the Old Sweet Springs Resort, OLDSWT, is reputed to be the work of Thomas Jefferson, the third president of the United States (Personal Communication, Amonda Moon, August, 2010). Like many of the old resorts that line the Appalachian Mountains, they were abandoned at the turn of the $20^{\text {th }}$ century. Old Sweet Springs Resort was reclaimed by the State of West Virginia and made into a tuberculosis sanitarium in 1941 (Clauson-Wicker, 2008). Buildings that were part of the resorts still exist on the respective properties, but they are unused and structurally unsound. Restoration is underway at Old Sweet Springs Resort; however, the restoration is in limbo as of the end of this thesis.

Travertine (travertine-marl) deposits have been exploited in the region surrounding the study area as well as in the Sweet Springs Valley itself. The marls themselves were greater than 90\% purity with respect to $\mathrm{CaCO}_{3}$ and were utilized as a flux in iron-making during the early twentieth century (Herman et al., 1990). The mined travertine was also utilized in agriculture and is still used today, including in the Sweet Springs Valley, as a cheap method of increasing soil $\mathrm{pH}$. 


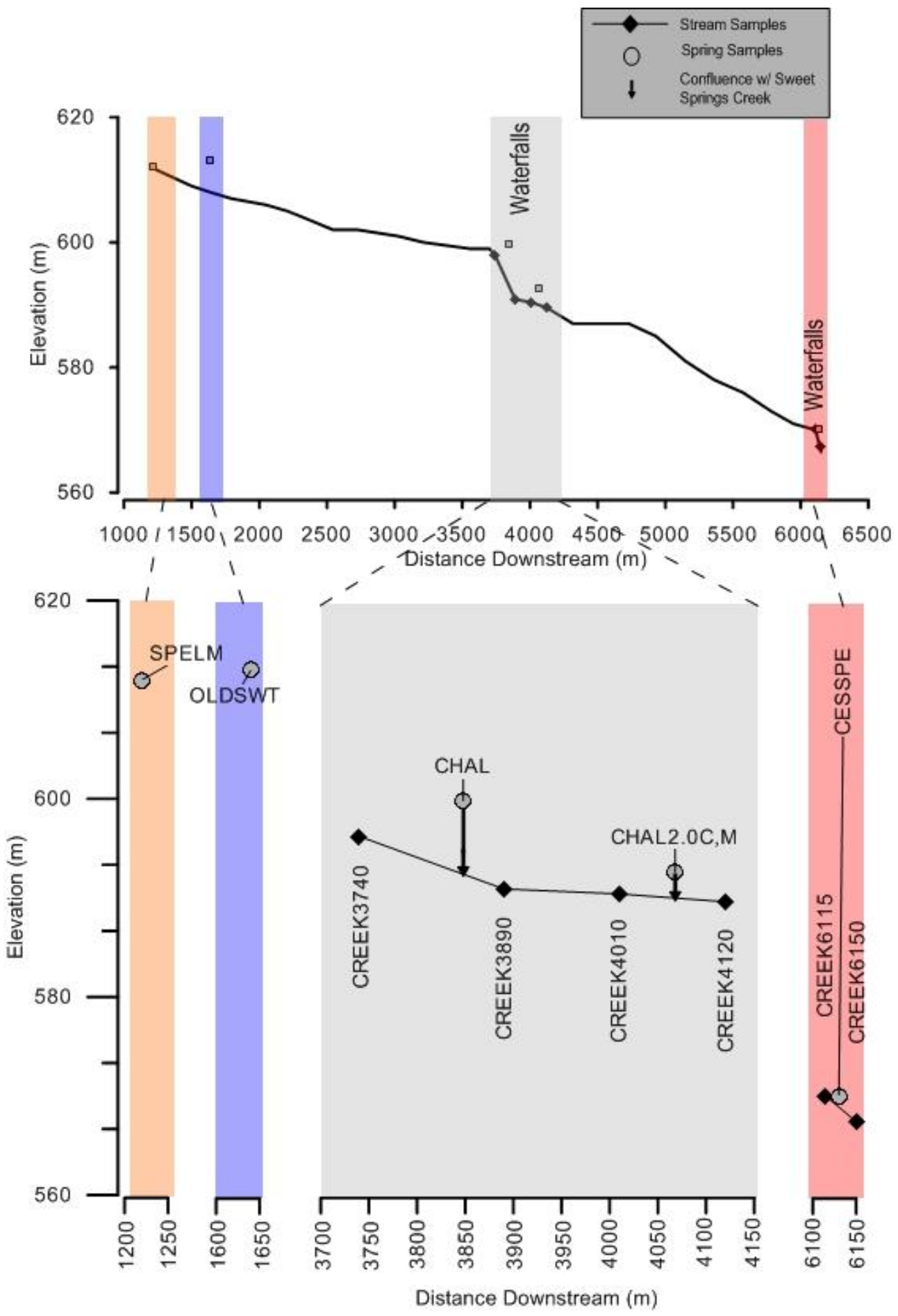

Figure 6 - Location of each site relative to Sweet Springs Creek while also comparing their position relative to absolute elevation. 
Table 2 - Sample site descriptions with location

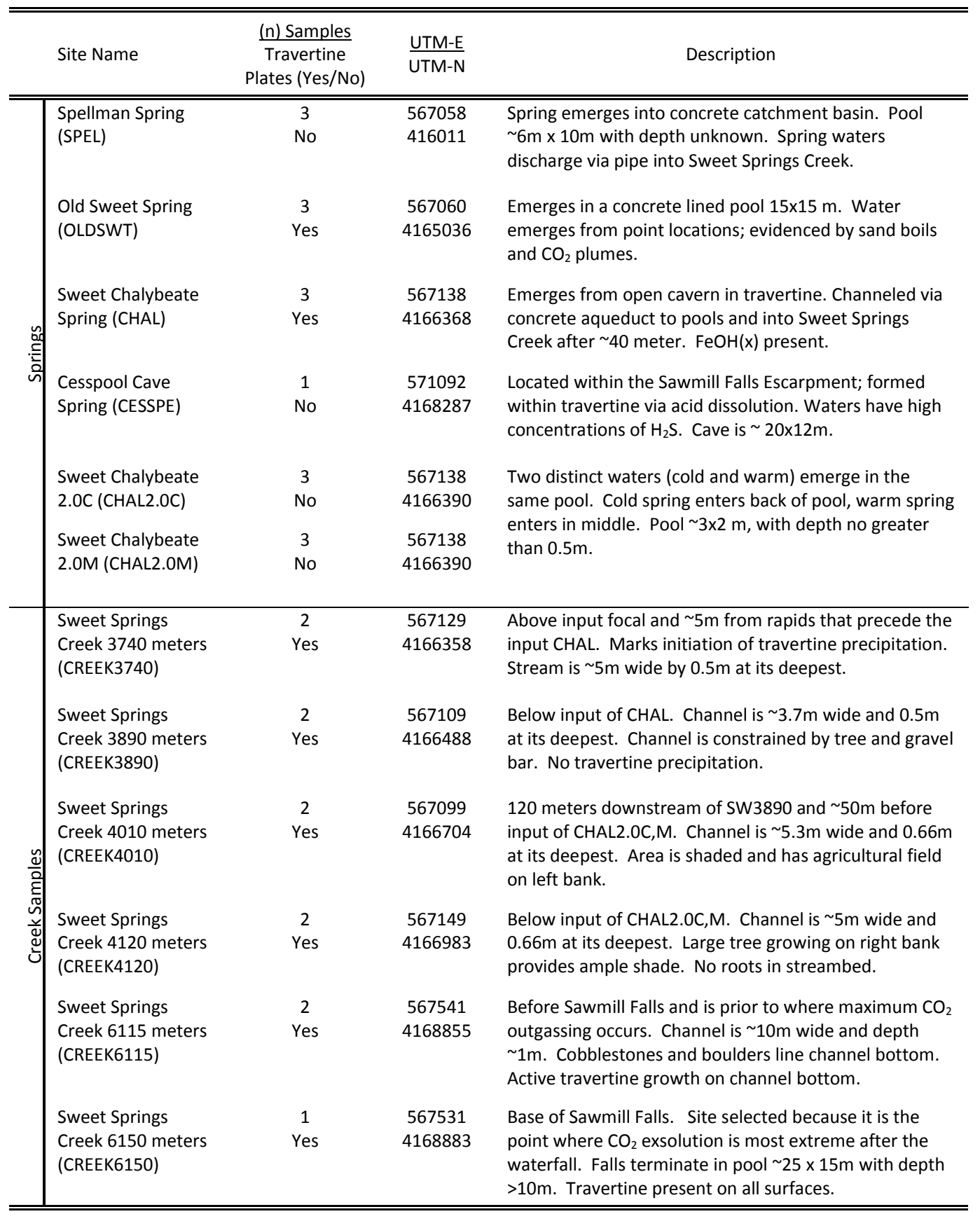




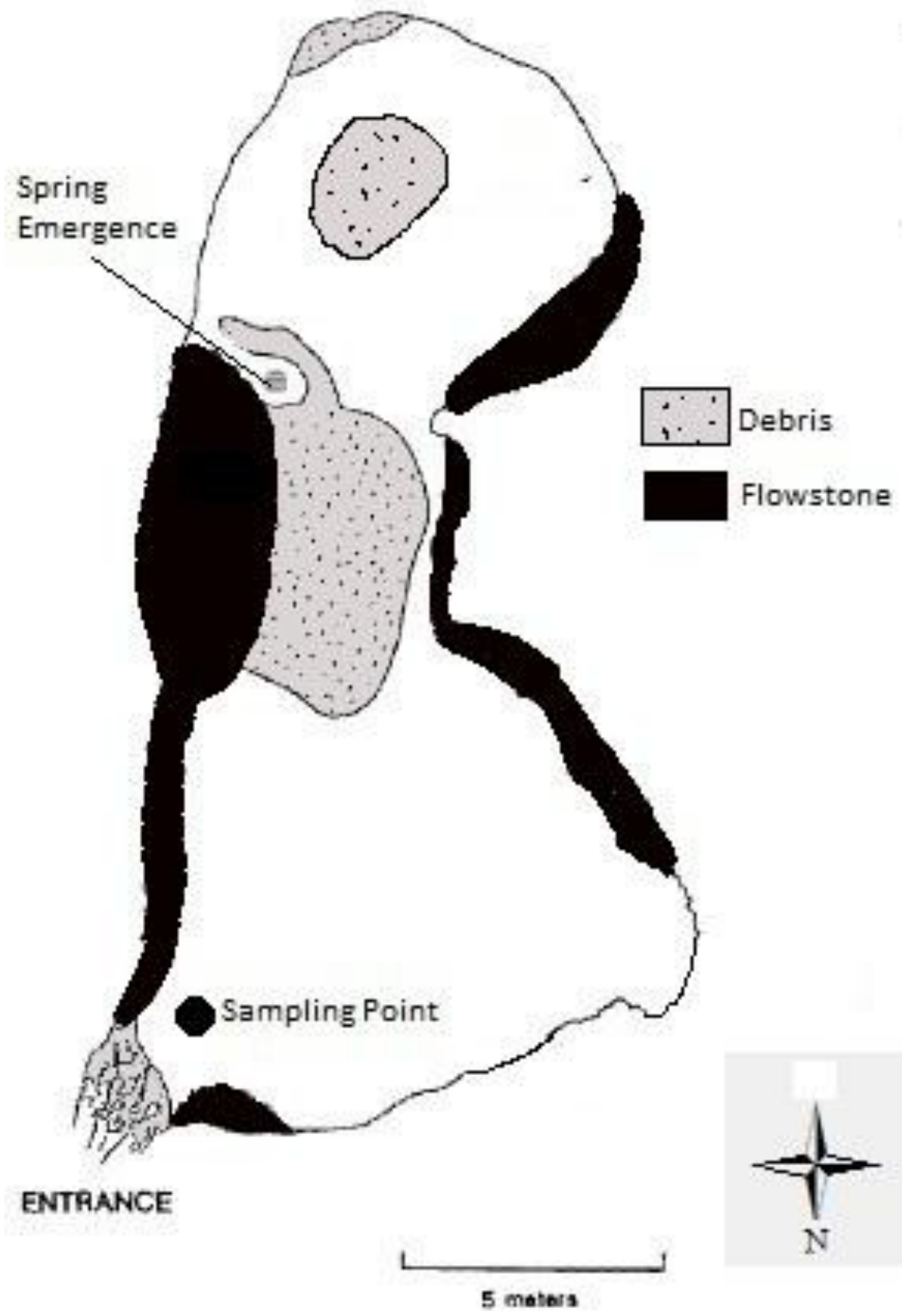

Figure 7 - Map view of Cesspool Cave. Modified from Hubbard et al. (1990) 


\subsection{Methods}

\subsection{Physical parameters}

\subsubsection{Discharge}

Discharge was measured at spring outlets and in Sweet Springs Creek. A standard cross sectional method for calculating discharge was used whereby mean velocity and area are taken in each cross-section and summed to calculate total discharge (Buchanan and Somers, 1969). Measurements were taken in straight channel segments where flow was constricted and unobstructed. Obstructions were removed prior to measurement in both the upstream and downstream segments of the channel. Each measuring segment was at least nine $\mathrm{cm}$ from the previous to minimize any overlap in measurement. The impeller was placed at approximately six tenths of the total stream depth to intercept the maximum flow in each subsection.

Discharge through each section is calculated as:

$$
\mathrm{Q}=\sum(\mathrm{a} v)
$$

where $Q=$ total discharge, $\Sigma$ denotes the summation of all partial sections, $a=$ area of partial section, and $v$ is the velocity of each subsection.

In May 2011, two discharge measurements were taken whereas August included three discharge measurements. The relative standard deviation (RSD), which is the standard deviation normalized to the mean expressed as a percentage, ranged from $0.8 \%$ to $4.3 \%$ and had an average of $2.4 \%$ for May, 2011. The RSD in August ranged from $0.9 \%$ to $10.9 \%$ and had an average of $5.7 \%$.

\subsubsection{Mineral precipitation plate installation}

Travertine tiles, quarried in Turkey, were cut to approximately $2.5 \mathrm{~cm} \times 2.5 \mathrm{~cm} \times 1 \mathrm{~cm}$. A $3.15 \mathrm{~mm}$ diameter hole was drilled into one corner of each plate to facilitate suspension in the water column. The hole drilled into the plates was accounted for by utilizing the following equation to calculate plate area:

$$
\text { Plate }_{\text {area }}=2(\mathrm{~L} 1 \times \mathrm{L} 2)+2(\mathrm{~L} 1 \times \text { thickness })+2(\mathrm{~L} 2 \times \text { thickness })-2\left(\pi \mathrm{r}^{2}\right)+2 \pi \mathrm{rh}_{\text {cylinder }}
$$

Where $\mathrm{L} 1$ and $\mathrm{L} 2$ are the two lengths of the plate respectively, $r$ is the radius of the hole drilled in the plate, and $h_{\text {cylinder }}$ is the thickness of the plate represented as the height of the cylinder created by the hole in the plate.

Plates were measured for all three dimensions using a Tresna ${ }^{\circledR}$ (Guilin Guanglu Measuring Instrument Co., Ltd., China) digital caliper with a precision of $0.01 \mathrm{~mm}$. The plates 
were subsequently dried for 8 hours at $70^{\circ} \mathrm{C}$ to remove all water vapor and then weighed using a Sartorius ${ }^{\circledR}$ (Sartorius AG, Germany) AC1215 digital scale with a precision of $0.001 \mathrm{~g}$. Plates with pores larger than $2 \mathrm{~mm}$ or that had excessive porosity ( $>1 / 4^{\text {th }}$ of plate surface), were removed from the study to eliminate erroneous surface area calculations; excess porosity would introduce underestimation of surface area and cause inflated estimates of total mass gained per area.

Plates were fastened to a $3 \mathrm{~mm}$ diameter copper wire by looping the wire through holes drilled in the plates and suspended in the water column (Figure 8). The rigidity of the wire enabled plates to be suspended away from the copper wire and into the water column. Stones were used to anchor the wire so that it remained taught in the current and the plates were oriented with one of the large faces oriented perpendicular to flow in order to maximize area exposed to the bulk solution. Plates were spaced approximately 1 plate width apart to ensure no contact with each other.

Plates were in-situ for up to 60 consecutive days and most were in place for 30 days. Plates that were installed in May were designated into group Plate Set $1 \mathrm{~A}$ for those in-situ for 30 days and Plate Set 1B for those installed for 60 days. Plates that were installed in August were designated as Plate Set 2. Time was limited to minimize the error associated with surface area changes due to precipitate accumulation, as noted by Gradzinski (2010).

Teflon ${ }^{\circledR}$ tiles were used for collection of pure precipitate so that it could be easily extracted. Tiles were cut to the same dimensions as the travertine plates but were only $1 \mathrm{~mm}$ thick. They were placed adjacent to travertine plates in sets of three and anchored in the same manner. One black ceramic tile, approximately $2.5 \mathrm{~cm}$ by $3 \mathrm{~cm}$, was placed along with the Teflon ${ }^{\circledast}$ tiles to gauge relative precipitation on non-porous, homogenous media and also to accumulate pure precipitate for analysis.

\subsubsection{Temperature/Light sensors}

Onset Hobo Pendant ${ }^{\circledR}$ Temperature Data Loggers (Onset, United States) accompanied each set of tiles with the exception SW6115 and SW6150. Loggers were placed at the base of the copper wire used to suspend precipitation plates and near the bottom of the springs in order to gauge relative temperature changes; large, non-diel temperature swings are indicative of rain 


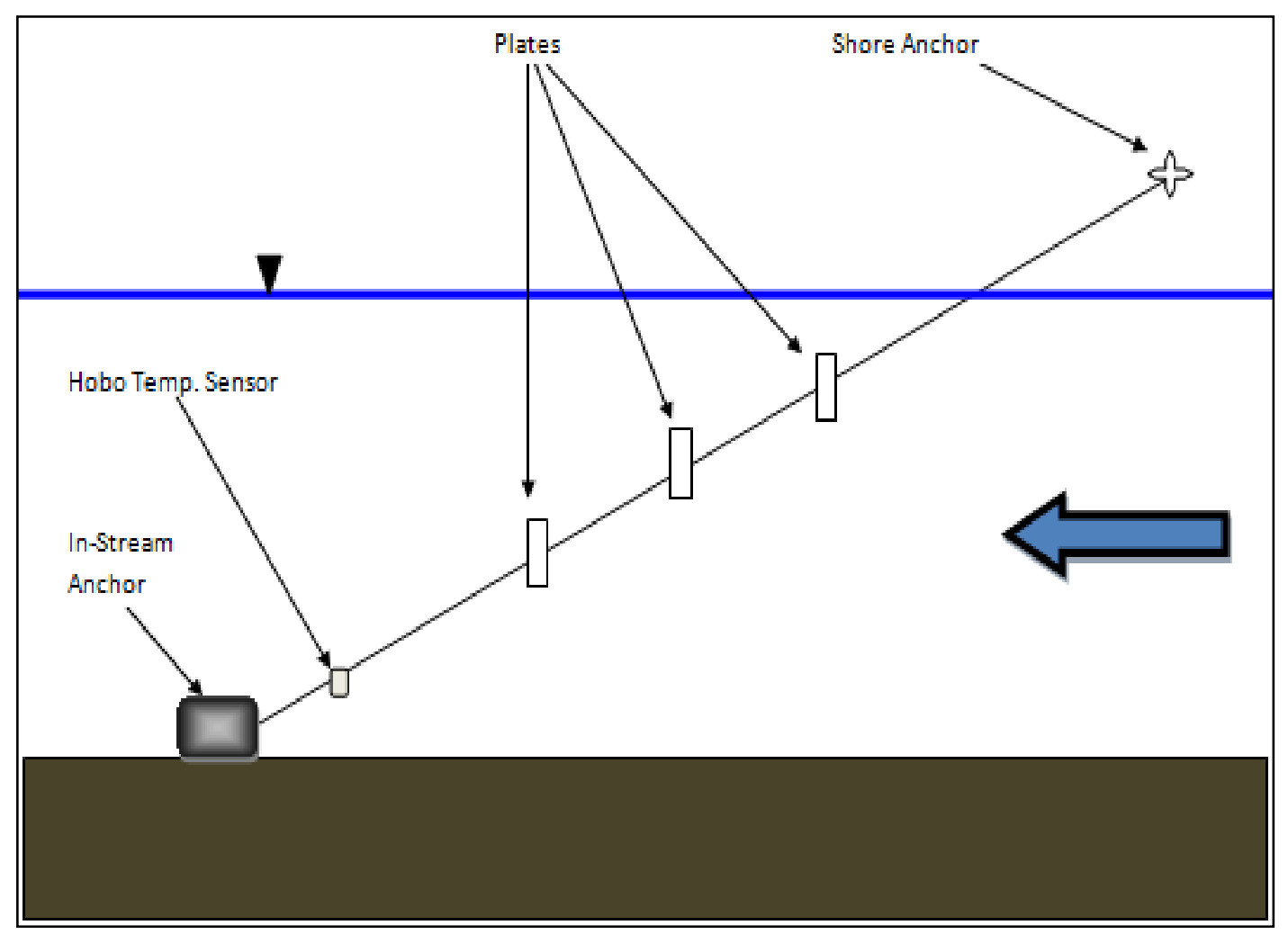

Figure 8-Representation of in-field precipitation plate assembly along with position of temperature sensor. 
precipitation events and thus can be used as a proxy for changes in discharge. Temperature data were recorded at ten minute intervals for the entirety of the study.

\subsection{Field chemical analysis}

\subsubsection{Carbon dioxide}

$\mathrm{CO}_{2}$ was measured using the CarboQC ${ }^{\odot}$ Carbonation Meter (Anton Paar GmbH, Austria). Details and reliability of measurements were evaluated in Vesper and Edenborn (2012).

Measurements with the $\operatorname{CarboQ}^{\odot}{ }^{\odot}$ involved passing at least $100 \mathrm{~mL}$ of sample through the instrument using roughly $20 \mathrm{~cm}$ of $\operatorname{Tygon}^{\odot}$ tubing attached to a $140 \mathrm{~mL}$ polyethylene syringe. The syringe was filled under water to limit degassing and the volume of water passed through the instrument flushes residue from previous samples.

Replicate measurements ( $>3$ ) in the field had a maximum STD of $0.53 \mathrm{mM} \mathrm{CO}_{2}$, which indicates a level of reproducibility within the error of the instrument. Experiments by Vesper and Edenborn in laboratory conditions with solutions of known $\mathrm{CO}_{2}$ concentration yielded RSD's ranging from $-1.8 \%$ to $6.8 \%$, illustrating a high degree of precision (2012).

\subsubsection{Alkalinity, $\mathrm{pH}$, specific conductivity, DO, and ORP}

Alkalinity was measured in the field or within 24-hours of sampling using the Gran Titration technique to pH 4.2 and 3.9 (Drever, 1997; Williams et al., 2009). Field titrations were performed using $50 \mathrm{~mL}$ of sample in an Erlenmeyer flask and titrating using a $\mathrm{Hach}^{\circledR}$ Digital Titrator Model 16900 with $1.6 \mathrm{~N}+/-0.008 \mathrm{~N} \mathrm{H}_{2} \mathrm{SO}_{4}$. Samples were titrated to a $\mathrm{pH}$ of 4.2 and 3.9 and the volume of acid necessary to reach each end point recorded. Alkalinity was replicated 6 times in one field run at CHAL with an average alkalinity of 11.8 meq $\mathrm{L}^{-1}$ with a STD of \pm 0.13 meq $\mathrm{L}^{-1}$. Alkalinity titrations were performed with unfiltered samples; a comparison of unfiltered versus filtered samples showed an average STD of \pm 0.18 meq $^{-1}$, which is within measurement error.

A YSI 556 Multiprobe Meter $^{\circledast}$ (YSI Inc, OH, United States) was utilized to measure temperature, $\mathrm{pH}$, dissolved oxygen (DO), specific conductivity $(\mathrm{SC})$, and the oxidation reduction potential (ORP). ZoBell's solution created in house utilizing methods from Nordstrom and Wilde (2005) was used to calibrate for ORP; calibration for SC used a $1.409 \mathrm{mS} \mathrm{cm}^{-1}$ solution created with $\mathrm{KCl}$. Dissolved oxygen was calibrated in the field using $10 \mathrm{~mL}$ of tap water in the calibration cup and leaving the cup partially open to the atmosphere for 10 minutes. Reference buffers of pH 4.0 and 7.0 were used to calibrate pH (Thermo Fisher Scientific, United States). 


\subsubsection{Hydrogen sulfide}

A Hach ${ }^{\circledR}$ DR2800 Spectrophotemeter (Hach Company, CO, United States) was used for analysis of dissolved $\mathrm{H}_{2} \mathrm{~S}$ using a modified version of the Hach Method 8131 which is a derivative of Method 376.2 developed by the United States Environmental Protection Agency (1983). Ferric chloride and dimethyl-4-phenylenediamine, known as Hach Sulfide Reagent $1^{\circledR}$ and Hach Sulfide Reagent $2^{\circ}$ respectively, were used to fix $\mathrm{H}_{2} \mathrm{~S}$ in a $10 \mathrm{~mL}$ glass sample cells. Combining the reagents in the presence of $\mathrm{H}_{2} \mathrm{~S}$ forms the dye complex methylene blue, which is spectrophotometrically measured at a wavelength of $562 \mathrm{~nm}$, with the absorbance proportional to concentration (Linsay and Baedecker, 1988). The samples were combined with the reagents in the field in order to "fix" the $\mathrm{H}_{2} \mathrm{~S}$ and keep it from oxidizing; the reagents effectively "Fix" or reduce the sulfide which immobilizes it in the dye complex (method protocol included in Appendix C). Samples were fixed because the detection limits of the Hach ${ }^{\circledR}$ DR2800 Spectrophotemeter are $5-800 \mu \mathrm{g} \mathrm{S}^{-2} \mathrm{~L}^{-1}$ and accurate dilution cannot be easily performed in the field.

Accuracy and precision of the "fixing" process was tested under laboratory conditions. A sampling set of five concentrations within the detection range was created from sulfide nonahydrate $\left(\mathrm{Na}_{2} \mathrm{~S} \cdot 9 \mathrm{H}_{2} \mathrm{O}\right)$ salt mixed with $\mathrm{DI}$ to make a solution with a concentration of 11,500 $\mu \mathrm{g} \mathrm{L}^{-1} \mathrm{~S}^{-2}$. Each solution set was subsequently measured in triplicates in three time intervals, comprising of less than 1 hour, 24 hours, and 48 hours after solution creation and dilution. The sample concentrations did not vary temporally; the concentrations remained stable throughout the 48 hours. RSD's ranged from $2.6 \%$ to $3.8 \%$ in samples with $>100 \mu \mathrm{g} \mathrm{L}^{-1} \mathrm{~S}^{-2}$. RSD was significantly higher, $19.7 \%$, in the sample set that was below $100 \mu \mathrm{g} \mathrm{L}^{-1} \mathrm{~S}^{-2}$.

\subsubsection{Dissolved Fe analysis}

A Hach DR2800 spectrophotometer was used for the analysis of dissolved $\mathrm{Fe}^{2+}$. Hach FerroZine $^{\circledR}$,[ 3-(2-pyridyl)-5,6-bis(4-phenylsulfonic acid)-1,2,4-triazine, monosodium salt, monohydrate], reacts with dissolved $\mathrm{Fe}^{2+}$ to form a purple color (Stookey, 1970). HEPES buffer was added to the FerroZine ${ }^{\circledR}$ in order to maintain a stable $\mathrm{pH}$ throughout the reaction.

For the analysis, $0.4 \mathrm{~mL}$ of sample was added to a cuvette pre-filled with $2 \mathrm{~mL}$ of FerroZine ${ }^{\circledR}$ solution. After allowing two minutes of reaction time, the sample absorbance was measured at $562 \mathrm{~nm}$. Four to six replicates were taken at each site. The STD ranged from 0.0 $\mathrm{mg} \mathrm{L}^{-1}$ to $0.08 \mathrm{mg} \mathrm{L}^{-1}$ with an average of $0.03 \mathrm{mg} \mathrm{L}^{-1}$ while the RSD ranged from $6.9 \%$ to $95 \%$ with an average of $29 \%$. 
The concentration in the field samples was determined by preparing calibration curves in the lab. All laboratory calibration curves used had an $\mathrm{R}^{2}>0.999$.

\subsection{Laboratory chemical analysis}

\subsubsection{Water samples}

Grab samples were taken at each site for analysis of major cations and anions. All samples were collected with a $60 \mathrm{~mL}$ polypropylene syringe (Becton-Dickinson and Company, $\mathrm{NJ}$, United States) filtered through Whatman ${ }^{\circledR} 0.45 \mu \mathrm{m}$ filters, and the bottles filled without headspace to minimize gas exchange. Cation samples were preserved using $1 \mathrm{~mL}$ of trace-metal grade $\mathrm{HNO}_{3}$ to prevent metal precipitation. All samples were put on ice or into fridge storage within 1 hour of collection to minimize biotic metabolization and growth.

Sampling procedures included collecting quality control samples. Filter blanks contained the cations $\mathrm{Na}^{+}$on all 4 occasions ranging from 7 to $171 \mu \mathrm{g} \mathrm{L}^{-1}$ and $\mathrm{K}^{+}$on three occasions ranging from 16 to $18 \mu \mathrm{g} \mathrm{L}^{-1}$. One filter blank, WVU-FB40453, had detectable concentrations of $\mathrm{Cl}^{-}, \mathrm{NO}_{3}{ }^{-}$, $\mathrm{Ba}^{+2}, \mathrm{Ca}^{+2}, \mathrm{Fe}^{+2,3}, \mathrm{Na}^{+}$, and $\mathrm{Zn}^{+2}$, and was the only filter blank anomaly (Appendix $\mathrm{B}$, Table 11B). Duplicate samples were taken on 4 occasions to compare repeatability and accuracy of the laboratory analyses. RSD among anions ranged between $0.1 \%$ and $6.8 \%$ with an average of $2.5 \%$ while cations ranged between $0.0 \%$ and $9.8 \%$ with an average of $8.6 \%$.

All samples were analyzed at the NETL in Pittsburgh, PA. Inductively Coupled Plasma Atomic Emission Spectroscopy (ICP-AES) with EPA Method 6010 B and Inductively Coupled Plasma Mass Spectrometry (ICP-MS) with EPA Method 6020 were used for the analysis of cations. Anions were analyzed using Ion Chromatography (IC) with EPA Method 300.1.

\subsubsection{Total organic carbon and total inorganic carbon}

Samples for total inorganic carbon (TIC) and total organic carbon (TOC) analysis were collected in $40 \mathrm{~mL}$ amber glass vials fitted with septa. Samples were collected by submerging the vial completely and capping underwater with no headspace. Samples were put on ice and refrigerated until analysis.

A Sievers 5310 C Laboratory Total Organic Carbon Analyzer (General Electric, CO, United States), was used for the analysis of TIC and TOC. The instrument uses a UV reactor in conjunction with a persulfate solution to oxidize the sample, where it subsequently uses proprietary $\mathrm{CO}_{2}$ permeable membranes to separate $\mathrm{CO}_{2}$ from the bulk solution. The resulting solution, with only $\mathrm{CO}_{2}$, is passed through a conductivity cell where the concentration of total 
carbon (TC) is determined relative to a base standard. TIC is determined as the difference between TC and TOC. The instrument reports concentrations as the total carbon, which is synonymous with the total dissolved carbon as used in the discussion and results section. The instrument analyzes each sample three times; the mean concentration is reported.

\subsection{Rate calculations}

The weights of the travertine plates were recorded before they were placed in the stream and springs. After a period of 30 days, the plates were removed and dried at $80^{\circ} \mathrm{C}$ for a period of not less than 24 hours and then the weights were again recorded. In order to find the rate of accumulation or loss, Eq. 6 was used with the change in weight and area of the plates:

$$
R=\frac{\left[\frac{\Delta \text { Plate Weight }}{\text { Plate Area }} \times \frac{1}{M W_{\text {calcite }}}\right]}{\text { Time }}
$$

Where $\mathrm{R}$ is the rate in $\mathrm{mol} \mathrm{cm}^{-2} \mathrm{~s}^{-1}, \mathrm{MW}_{\text {calcite }}$ is the molecular weight of calcite and all mass change is assumed to be from calcite precipitation or dissolution. The equation was used for each plate and the time was approximated to within an hour of the installation and removal time. Positive rates indicate dissolution of calcite; negative rates indicate precipitation of calcite.

The PWP calcite precipitation rate (Plummer et al., 1978) was used for comparison with the plates. The equation utilizes rate constants and activities to evaluate the dissolution or precipitation rate of calcite (Eq. 7).

$$
R=k_{1} a_{\mathrm{H}+}+k_{2} a_{\mathrm{H} 2 \mathrm{CO} 3}+k_{3} a_{\mathrm{H} 2 \mathrm{O}}-k_{4} a_{\mathrm{Ca} 2+} a_{\mathrm{HCO} 3-}
$$

Where $\mathrm{H}_{2} \mathrm{CO}_{3} *$ is $\mathrm{H}_{2} \mathrm{CO}_{3}+\mathrm{CO}_{2}(\mathrm{aq}), \mathrm{k}_{1}+\mathrm{k}_{2}+\mathrm{k}_{3}$ are forward rate constants and $\mathrm{k}_{4}$ is the backwards rate constant.

The $\mathrm{k}_{4}$ term was derived entirely based on temperature and $\mathrm{P}_{\mathrm{CO} 2}$ determined in laboratory experiments. The term accounts for the complete precipitation reaction of calcite in a given solution. In any given carbonate system, the $\mathrm{pH}$ is in large part a function of $\mathrm{P}_{\mathrm{CO} 2}$, which is assumed to be the same at the crystal surface as it is in the bulk solution and as such the $\mathrm{k}_{4}$ term assumes that the activity of $\mathrm{H}^{+}$in solution is representative of the bulk surface activity of $\mathrm{H}^{+}$ (Eq. 8).

$$
k_{4}=\frac{K_{2}}{K_{c}} \times k_{1}^{\prime}+\frac{1}{a_{H(s)}} \times\left(\mathrm{k}_{2} a_{\mathrm{H} 2 \operatorname{CO} 3(\mathrm{~s})}+\mathrm{k}_{3} a_{\mathrm{H} 2 \mathrm{O}(\mathrm{s})}\right)
$$

where

$\mathrm{K}_{2}$ is the second dissociation constant for carbonic acid at given temperature 
$\mathrm{K}_{\mathrm{C}}$ is the equilibrium constant for calcite at given temperature

$\mathrm{k}_{1}^{\prime}$ is a corrected $\mathrm{k}_{1}$ term for the forward rate reaction

$a_{(\mathrm{s})}$ denotes activity of the specie at the calcite surface

and

$$
\begin{aligned}
& K_{2}=-\frac{2902.39}{T}+6.498-0.02379 T \\
& K_{C}=13.87-\frac{3059}{T}-0.0403 T \\
& k_{1}^{\prime}=10 \times k 1 \\
& a_{\text {(s) }}=a_{\text {(aqueous) }} \text { for all species }
\end{aligned}
$$

All PWP rates were left in the form of the original PWP equation, so that sign conventions on the PWP rates are the same as used for field measurements.

The current study assumes that all chemical activities on solid surfaces are equal to the bulk solution values and that $\mathrm{k}_{1}{ }_{1}$ is exactly 10 times the value of $\mathrm{k}_{1}$ as has been done in previous studies (Dreybrodt et al., 1992; Herman and Lorah, 1988; Lu et al., 2000; Zaihua et al., 1995). The activity variations between the crystal surface and bulk solution are not believed to greatly impact the value of $\mathrm{k}_{4}$ as the term is predominantly dependent on $\mathrm{P}_{\mathrm{CO} 2}$ and temperature.

\subsection{Plate surface and precipitate analysis}

\subsubsection{Scanning electron microscope \& electron dispersive spectrometry}

One plate from each stream sample site was examined utilizing an Etec Autoscan (Etec Corp, United States) scanning electron microscope (SEM) fitted with an EDAX (Edax Corp, United States) system for electron dispersive spectrometry (EDS) at the United States Geological Survey (USGS) in Reston, Virginia.

The instrument was focused at $40 x$ magnification, an area approximately $2.5 \mathrm{~cm}^{2}$, and left to scan for a period of approximately 200 seconds on each plate at voltage of 15 kilo electron volts (KeV), meaning thousands of electron volts. The elemental surface analysis results were then recorded and the process repeated a total of 5 times at different locations on the respective plate. The values were averaged to show a "relative composite" elemental chemistry of the precipitate on plate surfaces.

An assumption was made that all $\mathrm{CaO}$ was complexed with $\mathrm{CO}_{2}$. This assumption allows for the conjecture that each mol of $\mathrm{CaO}$ is matched to one mol of $\mathrm{CO}_{2}$ and thus can be corrected 
for the missing $\mathrm{CO}_{2}$ that should be present $\left(\mathrm{as}_{\mathrm{CaCO}}\right)$ and not detected by EDS. All elements were then normalized relative to the addition of $\mathrm{CO}_{2}$ (Table 3). This methodology is assumed to be viable for plate samples from CREEK3740 and CREEK6115 as they had enough mineral precipitate to mask the substrate; the electron beam penetrated to a depth of no more than 15 $\mu \mathrm{m}$, meaning it would not have penetrated to the plate substrate (Personal Communication, Dan Doctor, August, 2012). However, this method can only be used for general comparison for the other plates as the mineral precipitate did not mask the background substrate entirely.

\subsubsection{Light microscopy}

A Leica M3Z stereo microscope (Leica Microsystems, Germany) was utilized at the NETL in Pittsburgh, PA to view the mineral precipitation plates. Plates were viewed in full spectrum light and pictures taken by a standard charge coupled device camera.

\subsubsection{X-Ray fluorescence fusion and total carbon}

X-Ray Fluorescence Fusion (XRF-F) was performed by Activation Laboratories Ltd.

(Ontario, Canada) utilizing a Panalytical Axios Advanced Wavelength Dispersive XRF (Panalytical, The Netherlands). The sample was first heated to remove all volatiles from the sample, which are referred to as loss on ignition (LOI), and was subsequently combined with lithium metaborate and lithium tetraborate to form sample disks. Sample disks were then subjected to $\mathrm{X}$-rays and the fluorescence intensity measured to calculate a total concentration via comparison to known standards.

The procedure reports oxide content of samples and also gauges relative volatile content through the combustion process. The limit of detection for all samples was $0.01 \%$ of the sample weight.

Total carbon was measured by Activation Laboratories Ltd. utilizing an Eltra CS-2000 automatic analyzer (Eltra GmbH, Germany). The sample was completely combusted using an induction furnace in a pure oxygen environment. Carbon in the sample combined with the oxygen to form $\mathrm{CO}_{2}$ which was then passed through a membrane filter that only allows $\mathrm{CO}_{2}$ to pass. The $\mathrm{CO}_{2}$ was then passed through an infrared field where the total absorbance was measured and considered as directly proportional to the amount of carbon present. 
Table 3 - Mineral analysis of plates utilizing SEM-EDS

\begin{tabular}{lccccccccc}
\hline \hline Site & $\mathrm{SO}_{3}$ & $\mathrm{MgO}$ & $\mathrm{Al}_{2} \mathrm{O}_{3}$ & $\mathrm{SiO}_{2}$ & $\mathrm{~K}_{2} \mathrm{O}$ & $\mathrm{CaCO}_{3}$ & $\mathrm{BaO}$ & $\mathrm{MnO}$ & $\mathrm{FeO}$ \\
\hline \hline Creek 3740 & 0.8 & 0.7 & 3.2 & 15.4 & 0.6 & 76.8 & 0.3 & 0.6 & 1.6 \\
Creek 3890 & 1.4 & 1.3 & 4.6 & 17.7 & 0.6 & 63.6 & 0.2 & 0.6 & 9.9 \\
Creek 4010 & 1.0 & 0.6 & 5.4 & 43.1 & 0.8 & 42.6 & 0.4 & 0.9 & 5.2 \\
Creek 4120 & 4.0 & 2.4 & 5.1 & 15.5 & 0.9 & 59.7 & 2.0 & 2.0 & 9.3 \\
Creek 6115 & 1.2 & 0.5 & 0.8 & 3.8 & 0.2 & 92.5 & 0.3 & 0.3 & 0.4 \\
\hline \hline
\end{tabular}

Note: all minerals normalized relative to $\mathrm{CaCO}_{3}(\%)$ 


\subsection{Visual Minteq modeling}

Visual Minteq ${ }^{\circledast}$ (Allison et al., 1991) was utilized to calculate all saturation indices, activities, aqueous speciation, and $\mathrm{P}_{\mathrm{CO} 2}$. Field parameters including alkalinity, temperature, and $\mathrm{pH}$ were used in conjunction with laboratory analyte results in the Visual Minteq ${ }^{\circledR}$ models. $^{\circ}$ 


\subsection{Results}

\subsection{Physical parameters and aqueous geochemistry}

\subsubsection{Physical parameters}

Discharge was measured for all sites with mineral precipitation plates installed in both May, 2011 and August, 2011 with the exception of OLDSWT (Table 4). CREEK3740 had an anomalously high discharge that was likely due to a rainfall precipitation event that occurred the previous day. Variability in stream discharge, up to an order of magnitude, between sampling trips was due to differences in rain precipitation. The spring discharges had lesser variability, with the largest variance being $<0.05 \mathrm{~m}^{3} \mathrm{~s}^{-1}$.

Temperature was taken during each sampling trip via YSI 556MP and was also recorded continuously with data loggers from May until September, 2011 (Table 5, Figure 9).

Temperature was on average $2.10^{\circ} \mathrm{C}$ higher during the August, 2011 sampling trip for stream samples than the May, 2011 samples. Little variability was observed in temperature for spring samples and was within the measurement error of the YSI 556MP except in CHAL2.0C and CHAL2.0M. CHAL2.0C and CHAL2.0M progressively showed warmer samples throughout the study.

\subsubsection{In-situ chemical characterization}

Specific conductivity (SC) was temporally variable in stream samples as well as in the CHAL2.0 Springs (Figure 10). Stream samples varied significantly more than spring samples, and were on average $455 \mu \mathrm{S} \mathrm{cm}^{-1}$ higher in August, 2011 samples than May, 2011 samples. CHAL2.0C and CHAL2.0M were the most variable among the spring samples, with a general increase in SC as the summer season of 2011 progressed. The other springs showed no variability tied to seasonality or rainfall precipitation.

The $\mathrm{pHs}$ were all near neutral. Spring waters ranged in $\mathrm{pH}$ from 6.2 to 7.2 , and were stable temporally, with deviations typically within $\pm 0.1 \mathrm{pH}$ units. Stream samples ranged in $\mathrm{pH}$ from 6.8 to 8.1 .

Thermal springs had higher concentrations of $\mathrm{CO}_{2}$ with $\mathrm{CHAL}$ having the highest (Table 6, Figure 11). SPELM and CESSPE had less $\mathrm{CO}_{2}$ than the thermal springs, averaging $0.33 \mathrm{mM}$ and $1.62 \mathrm{mM}$ respectively. Stream samples had less $\mathrm{CO}_{2}$ than thermal springs as well, never having more than $1.27 \mathrm{mM} \mathrm{CO}_{2}$. Stream samples had $\mathrm{CO}_{2}$ concentrations in August, 2011 that were on average $0.47 \mathrm{mM}$ higher than those from May, 2011. 
Table 4 - Discharge measurements

\begin{tabular}{lllccc}
\hline \hline Site & Date & (n) & $\begin{array}{c}\text { Q Mean } \\
\left(\mathrm{m}^{3} \mathrm{~s}^{-1}\right)\end{array}$ & $\begin{array}{c}\text { Q STD } \\
\left(\mathrm{m}^{3} \mathrm{~s}^{-1}\right)\end{array}$ & $\begin{array}{c}\text { RSD } \\
(\%)\end{array}$ \\
\hline \hline CREEK3740 & $5 / 26 / 11$ & 2 & $8.97 \mathrm{E}-01$ & $3.32 \mathrm{E}-02$ & 3.71 \\
CHAL & $5 / 27 / 11$ & 2 & $8.33 \mathrm{E}-02$ & $2.80 \mathrm{E}-03$ & 3.37 \\
CREEK3890 & $5 / 27 / 11$ & 2 & $5.47 \mathrm{E}-01$ & $6.21 \mathrm{E}-03$ & 1.14 \\
CHAL2.0M & $5 / 28 / 11$ & 2 & $9.34 \mathrm{E}-03$ & $4.00 \mathrm{E}-04$ & 4.29 \\
CREEK6115 & $5 / 28 / 11$ & 2 & $8.98 \mathrm{E}-01$ & $7.01 \mathrm{E}-03$ & 0.78 \\
CREEK4010 & $5 / 29 / 11$ & 2 & $7.07 \mathrm{E}-01$ & $7.41 \mathrm{E}-03$ & 1.05 \\
CREEK4120 & $5 / 29 / 11$ & 2 & $7.24 \mathrm{E}-01$ & $1.00 \mathrm{E}-02$ & 1.38 \\
\hline CHAL & $8 / 2 / 11$ & 3 & $3.37 \mathrm{E}-02$ & $2.04 \mathrm{E}-03$ & 6.06 \\
CREEK3740 & $8 / 2 / 11$ & 3 & $8.16 \mathrm{E}-02$ & $5.59 \mathrm{E}-03$ & 6.85 \\
CREEK3890 & $8 / 2 / 11$ & 3 & $1.32 \mathrm{E}-01$ & $2.63 \mathrm{E}-03$ & 2.00 \\
CREEK4010 & $8 / 2 / 11$ & 3 & $1.42 \mathrm{E}-01$ & $1.34 \mathrm{E}-03$ & 0.94 \\
CREEK4120 & $8 / 2 / 11$ & 3 & $1.60 \mathrm{E}-01$ & $1.51 \mathrm{E}-02$ & 9.40 \\
CHAL2.0M & $8 / 3 / 11$ & 2 & $2.00 \mathrm{E}-04$ & $2.00 \mathrm{E}-04$ & 11.0 \\
CREEK6115 & $8 / 3 / 11$ & 3 & $1.35 \mathrm{E}-01$ & $4.79 \mathrm{E}-03$ & 3.54 \\
\hline \hline
\end{tabular}

Note: $\mathrm{Q}=$ discharge; $(\mathrm{n})$ =number of replicates; STD=standard deviation; RSD=relative standard deviation 
Table 5 - Temperature, specific cond. (SC), and pH

\begin{tabular}{lcccc}
\hline \hline Sample ID & Date & Temperature $\left(\mathrm{C}^{\circ}\right)$ & $\mathrm{SC}\left(\mu \mathrm{Sm}^{-1}\right)$ & $\mathrm{pH}$ \\
\hline \hline CHAL & $8 / 10 / 10$ & 23.3 & 1870 & 6.3 \\
OLDSWT & $8 / 10 / 10$ & 22.7 & 1690 & 6.3 \\
\hline CHAL & $9 / 25 / 10$ & 23.4 & 1900 & 6.3 \\
OLDSWT & $9 / 25 / 10$ & 22.8 & 1710 & 6.4 \\
SPELM & $9 / 25 / 10$ & 12.5 & 441 & 7.2 \\
\hline CHAL & $11 / 20 / 10$ & 23.4 & 1910 & 6.3 \\
OLDSWT & $11 / 20 / 10$ & 22.3 & 1720 & 6.4 \\
CESSPE & $11 / 21 / 10$ & 12.8 & 932 & 6.8 \\
CREEK6115 & $11 / 21 / 10$ & 13.1 & 1140 & 7.7 \\
\hline CREEK3740 & $5 / 26 / 11$ & 15.9 & 396 & 7.6 \\
OLDSWT & $5 / 27 / 11$ & 22.2 & 1680 & 6.3 \\
CHAL & $5 / 27 / 11$ & 22.9 & 1820 & 6.3 \\
CREEK3890 & $5 / 27 / 11$ & 18.2 & 458 & 7.7 \\
CREEK6115 & $5 / 28 / 11$ & 18.6 & 610 & 7.2 \\
CHAL2.0M & $5 / 28 / 11$ & 19.0 & 1370 & 6.3 \\
CHAL2.0C & $5 / 28 / 11$ & 16.1 & 980 & 6.4 \\
CREEK4010 & $5 / 29 / 11$ & 15.9 & 570 & 6.9 \\
CREEK4120 & $5 / 29 / 11$ & 15.1 & 580 & 6.8 \\
\hline SPELM & $6 / 28 / 11$ & 12.5 & 429 & 7.2 \\
OLDSWT & $6 / 28 / 11$ & 22.7 & 1700 & 6.3 \\
CHAL & $6 / 28 / 11$ & 23.2 & 1790 & 6.2 \\
CHAL2.0C & $6 / 28 / 11$ & 19.0 & 1430 & 6.3 \\
CHAL2.0M & $6 / 28 / 11$ & 21.2 & 1660 & 6.4 \\
CESSPE & $6 / 28 / 11$ & 13.0 & 934 & 6.9 \\
\hline OLDSWT & $8 / 1 / 11$ & 22.7 & 1710 & 6.6 \\
CHAL & $8 / 2 / 11$ & 23.4 & 1090 & 6.2 \\
CREEK3740 & $8 / 2 / 11$ & 16.2 & 1050 & 7.4 \\
CREEK3890 & $8 / 2 / 11$ & 17.2 & & 7.1 \\
CREEK4010 & $8 / 2 / 11$ & 19.9 & 1080 & 6.4 \\
CREEK4120 & $8 / 2 / 11$ & 19.4 & 21.1 & 6.9 \\
CHAL2.0C & $8 / 3 / 11$ & 21.3 & 13.4 & 6.8 \\
CHAL2.0M & $8 / 3 / 11$ & 20.1 & 20.3 & 6.9 \\
CESSPE & $8 / 3 / 11$ & & & \\
\hline \hline
\end{tabular}




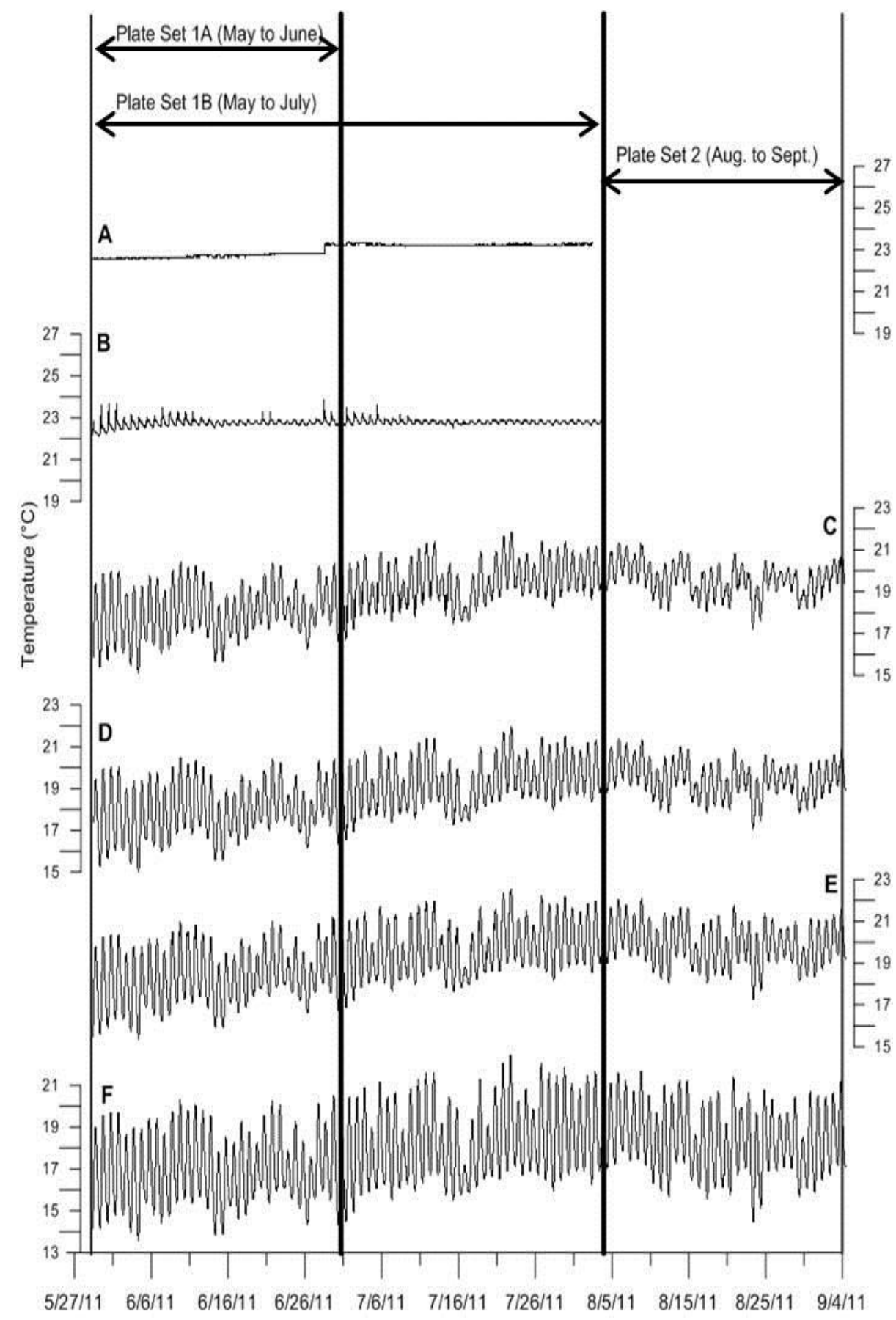

Figure 9 - Temperature records for (A) CHAL, (B) OLDSWT, (C) CREEK4120, (D) CREEK4010, (E) CREEK3890, and (F) CREEK3740. All plots have the same temperature scale on the $Y$ Axis. 

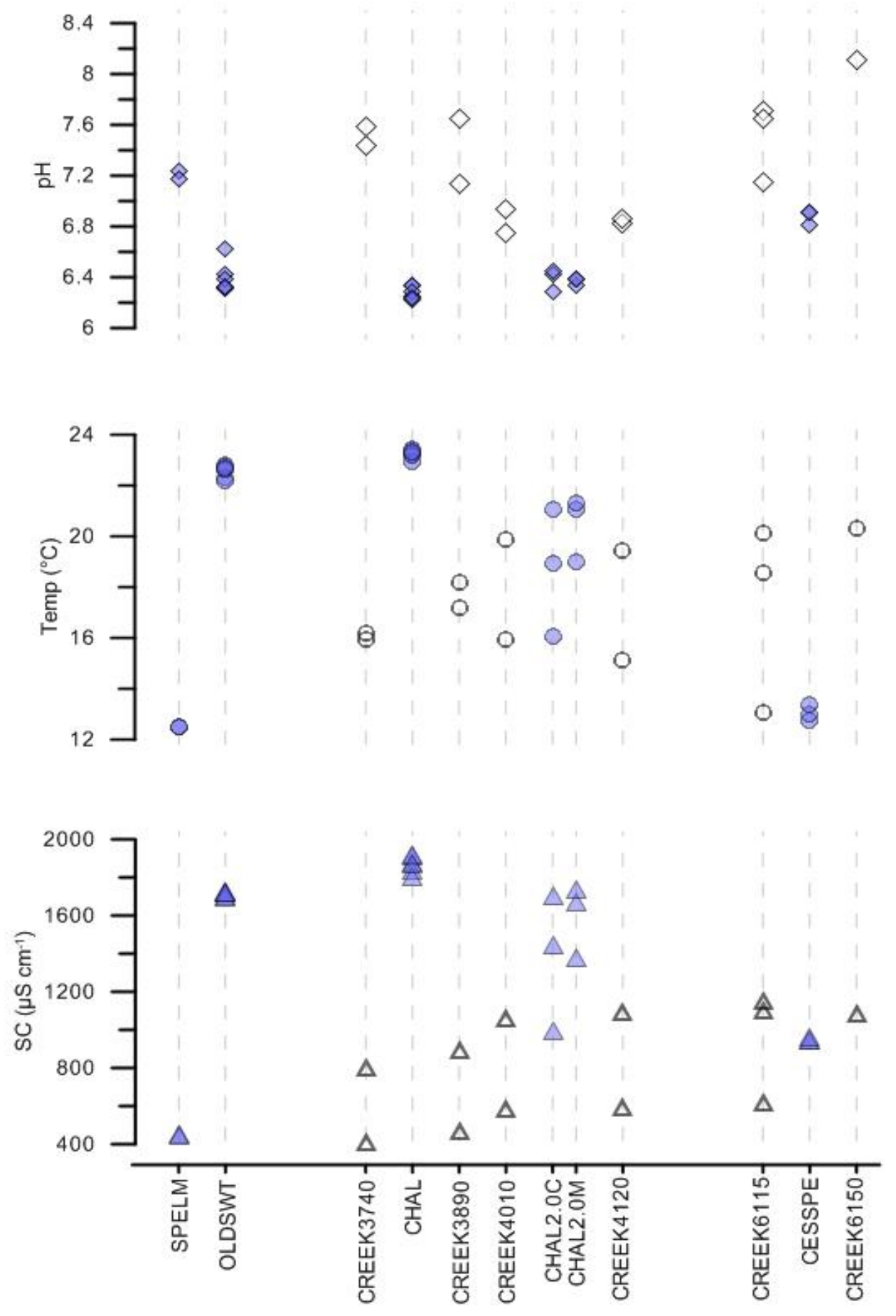

Figure 10 - Comparison of $\mathrm{pH}$, Specific Conductivity (SC), and Temperature for all sampling sites. Each point represents a discrete sampling run where springs are shaded and stream samples are hollow. 
Table $6-\mathrm{CO}_{2}$ and alkalinity measurements

\begin{tabular}{|c|c|c|c|c|c|c|}
\hline Sample ID & Date & $\begin{array}{l}(\mathrm{n}) \\
\mathrm{CO}_{2}\end{array}$ & $\begin{array}{c}\text { Average } \mathrm{CO}_{2} \\
(\mathrm{mM})\end{array}$ & $\begin{array}{l}\text { STD } \\
(\mathrm{mM})\end{array}$ & $\begin{array}{l}\text { RSD } \\
(\%)\end{array}$ & $\begin{array}{l}\text { Alkalinity } \\
\left(\text { meq } L^{-1}\right)\end{array}$ \\
\hline $\mathrm{CHAL}$ & $8 / 10 / 10$ & 3 & 10.6 & 0.05 & 0.45 & 12.6 \\
\hline OLDSWT & $8 / 10 / 10$ & 13 & 7.68 & 0.14 & 1.76 & 11.6 \\
\hline $\mathrm{CHAL}$ & $9 / 25 / 10$ & 4 & 11.0 & 0.09 & 0.80 & 12.8 \\
\hline OLDSWT & $9 / 25 / 10$ & 17 & 7.82 & 0.20 & 2.58 & 11.4 \\
\hline SPELM & $9 / 25 / 10$ & na & - & - & - & 4.4 \\
\hline $\mathrm{CHAL}$ & $11 / 20 / 10$ & na & - & - & - & 10.9 \\
\hline OLDSWT & $11 / 20 / 10$ & 6 & 7.68 & 0.17 & 2.21 & 11.6 \\
\hline CESSPE & $11 / 21 / 10$ & na & - & - & - & 5.2 \\
\hline CREEK6115 & $11 / 21 / 10$ & na & - & - & - & na \\
\hline CREEK3740 & $5 / 26 / 11$ & 6 & 0.37 & 0.10 & 27.8 & 3.1 \\
\hline OLDSWT & $5 / 27 / 11$ & 3 & 6.92 & 0.07 & 1.00 & 10.8 \\
\hline $\mathrm{CHAL}$ & $5 / 27 / 11$ & 3 & 9.89 & 0.14 & 1.46 & 11.6 \\
\hline CREEK3890 & $5 / 27 / 11$ & 4 & 0.27 & 0.03 & 12.8 & 3.2 \\
\hline CREEK6115 & $5 / 28 / 11$ & 5 & 0.50 & 0.03 & 5.25 & 5.0 \\
\hline CHAL2.0M & $5 / 28 / 11$ & 4 & 5.17 & 0.08 & 1.46 & 9.7 \\
\hline CHAL2.0C & $5 / 28 / 11$ & 4 & 3.73 & 0.53 & 14.3 & 7.4 \\
\hline CREEK4010 & $5 / 29 / 11$ & 3 & 0.77 & 0.02 & 2.94 & 4.5 \\
\hline CREEK4120 & $5 / 29 / 11$ & 3 & 0.77 & 0.06 & 7.78 & 4.3 \\
\hline SPELM & $6 / 28 / 11$ & 3 & 0.33 & 0.05 & 16.1 & 4.4 \\
\hline OLDSWT & $6 / 28 / 11$ & 4 & 8.95 & 0.07 & 0.83 & 12.9 \\
\hline $\mathrm{CHAL}$ & $6 / 28 / 11$ & 4 & 10.4 & 0.05 & 0.53 & 12.0 \\
\hline CHAL2.0C & $6 / 28 / 11$ & na & - & - & - & 10.3 \\
\hline CHAL2.0M & $6 / 28 / 11$ & 4 & 6.41 & 0.06 & 1.00 & 10.5 \\
\hline CESSPE & $6 / 28 / 11$ & 4 & 1.60 & 0.07 & 4.34 & 7.7 \\
\hline OLDSWT & $8 / 1 / 11$ & 4 & 7.87 & 0.23 & 2.95 & 11.0 \\
\hline $\mathrm{CHAL}$ & $8 / 2 / 11$ & 4 & 10.8 & 0.13 & 1.24 & 12.2 \\
\hline CREEK3740 & $8 / 2 / 11$ & 4 & 0.34 & 0.02 & 6.49 & 5.8 \\
\hline CREEK3890 & $8 / 2 / 11$ & 4 & 0.85 & 0.06 & 7.06 & 6.4 \\
\hline CREEK4010 & $8 / 2 / 11$ & 4 & 1.27 & 0.03 & 2.06 & 7.3 \\
\hline CREEK4120 & $8 / 2 / 11$ & 4 & 1.09 & 0.03 & 2.95 & 7.5 \\
\hline CHAL2.0C & $8 / 3 / 11$ & 4 & 6.46 & 0.33 & 5.10 & 10.9 \\
\hline CHAL2.0M & $8 / 3 / 11$ & 4 & 6.85 & 0.07 & 1.00 & 10.7 \\
\hline CESSPE & $8 / 3 / 11$ & 4 & 1.64 & 0.09 & 5.58 & 8.2 \\
\hline CREEK6115 & $8 / 3 / 11$ & 4 & 0.49 & 0.01 & 2.69 & 7.3 \\
\hline CREEK6150 & $8 / 3 / 11$ & 4 & 0.30 & 0.02 & 6.28 & 7.5 \\
\hline
\end{tabular}

Notes: sample parameters that are not available have the designation na 

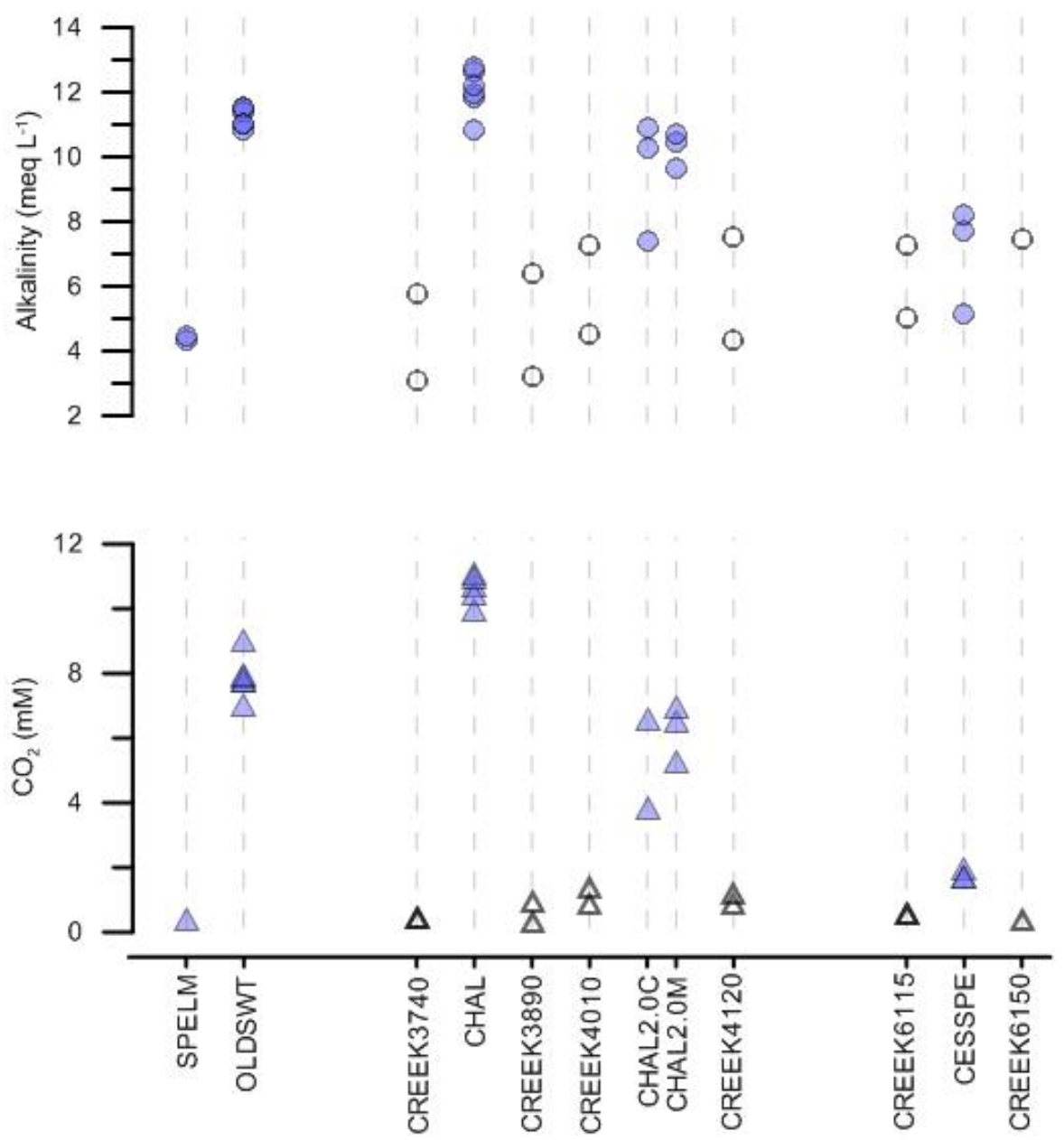

Figure 11 - Comparison of alkalinity and $\mathrm{CO}_{2}$ for all sampling sites. Each point represents a discrete sampling run where springs are shaded and stream samples are hollow. 
Alkalinity and $\mathrm{CO}_{2}$ increased correspondingly in all samples. $\mathrm{CHAL}$ had the highest average alkalinity at $12.0 \mathrm{meq} \mathrm{L}^{-1}$ while the lowest average alkalinity was at SPELM with $4.39 \mathrm{meq} \mathrm{L}^{-1}$. The creek samples had seasonally variable alkalinities and were highest during August, 2011. Ferric iron $\left(\mathrm{Fe}^{2+}\right)$ concentrations were $<1 \mathrm{mg} \mathrm{L}^{-1}$ or below detection for all samples with the exception of CESSPE which had $1.32 \mathrm{mg} \mathrm{L}^{-1}$ during the August, 2011 sampling trip; one sample out of the four replicates for CESSPE had $2.82 \mathrm{mg} \mathrm{L}^{-1}$ which biased the average (Appendix B, Table 8). The average RSD for all samples was $33 \%$.

$\mathrm{H}_{2} \mathrm{~S}$ was below detection limit for the majority of samples (Appendix $B$, Table 9). The average concentration for samples other than CESSPE was $20 \mu \mathrm{g} \mathrm{L}^{-1}$ as $\mathrm{S}^{-2}$. CESSPE had concentrations ranging from 1,404 to $4,263 \mu \mathrm{g} \mathrm{L}^{-1}$ as S $\mathrm{S}^{-2}$. The average RSD was $19.2 \%$.

\subsubsection{Lab Chemistry}

Predominant ions in all samples were $\mathrm{Ca}^{2+}, \mathrm{K}^{+}, \mathrm{Mg}^{2+}, \mathrm{Na}^{+}, \mathrm{Cl}^{-}, \mathrm{HCO}_{3}{ }^{-}$, and $\mathrm{SO}_{4}^{-2}$ (Table 7), and accounted for $\geq 98 \%$ of the ionic speciation in all aqueous samples. $\mathrm{Ca}^{2+}$ and $\mathrm{HCO}_{3}{ }^{-}$were the dominant ions accounting for $\geq 63 \%$ of all cation charge and $\geq 52 \%$ of all anion charge respectively (Figure 12). $\mathrm{Ca}^{2+}$ concentrations were temporally consistent for spring samples, with an average difference of $9.0 \%$ between sample dates. In stream samples, $\mathrm{Ca}^{2+}$ was highly variable between the sampling dates, with May, 2011 samples averaging $84 \mathrm{mg} \mathrm{L}^{-1}$ and August, 2011 samples averaging $161 \mathrm{mg} \mathrm{L}^{-1}$. The $\mathrm{SO}_{4}{ }^{2-}$ concentrations trended in a similar fashion to $\mathrm{Ca}^{2+}$, with springs differing by an average of $14.6 \%$. Stream samples had average $\mathrm{SO}_{4}{ }^{-2}$ concentrations of $67 \mathrm{mg} \mathrm{L}^{-1}$ and $164 \mathrm{mg} \mathrm{L}^{-1}$ for May, 2011 and August, 2011 respectively. Ionic species tended to increase in concentration downstream in both sample sets with the exception of CREEK3740 in the May, 2011 sample set which is anomalously high with respect to all ionic species.

Analysis of TIC, TOC, and TC was performed for samples for August, 2011 and for selected samples from May, 2011 (Table 8). OLDSWT was measured in triplicate and CREEK6115 and CREEK6150 were analyzed in duplicate to determine precision of the measurement. For OLDSWT the measurements were consistent with average RSD's for the sets at $\leq 16.0 \%, \leq 6.0 \%$, and $\leq 2.7 \%$ for TOC, TIC, and TC respectively. CREEK6115 and CREEK6150 were not consistent for TOC with the average RSD among the two samples at 33\%. These samples were also the lowest organic carbon for the August, 2011 sample set, which may be indicative of a variance among very low concentrations creating a much larger RSD. Only OLDSWT and 
Table 7 - Major cation and anion data

\begin{tabular}{|c|c|c|c|c|c|c|c|}
\hline Sample ID & Date & $\mathrm{Ca}$ & $\mathrm{K}$ & $\mathrm{Mg}$ & $\mathrm{Na}$ & $\mathrm{Cl}$ & $\mathrm{SO}_{4}$ \\
\hline CHAL & $8 / 10 / 10$ & 288 & 27 & 58 & 20 & 33 & 450 \\
\hline OLDSWT & $8 / 10 / 10$ & 268 & 24 & 56 & 18 & 29 & 400 \\
\hline $\mathrm{CHAL}(\mathrm{D})$ & $9 / 25 / 10$ & 311 & 33 & 58 & 21 & 36 & 430 \\
\hline $\mathrm{CHAL}$ & $9 / 25 / 10$ & 324 & 31 & 56 & 21 & 36 & 400 \\
\hline OLDSWT & $9 / 25 / 10$ & 278 & 27 & 53 & 17 & 31 & 402 \\
\hline SPELM & $9 / 25 / 10$ & 59 & 2.3 & 18 & 1 & 4 & 13 \\
\hline $\mathrm{CHAL}$ & $11 / 20 / 10$ & 341 & 33 & 62 & 24 & 33 & 441 \\
\hline OLDSWT & $11 / 20 / 10$ & 290 & 27 & 55 & 20 & 29 & 376 \\
\hline CESSPE & $11 / 21 / 10$ & 162 & 5 & 17 & 9 & 16 & 116 \\
\hline CREEK6115 & $11 / 21 / 10$ & 177 & 14 & 11 & 11 & 16 & 224 \\
\hline OLDSWT & $5 / 27 / 11$ & 280 & 23 & 32 & 18 & 28 & 386 \\
\hline $\mathrm{CHAL}$ & $5 / 27 / 11$ & 295 & 26 & 26 & 20 & 31 & 439 \\
\hline CREEK3740 & $5 / 27 / 11$ & 73 & 3 & 8.2 & 4 & 6 & 46.5 \\
\hline CREEK3890 & $5 / 28 / 11$ & 60 & 3 & 6.9 & 3 & 5 & 37 \\
\hline CREEK6115 & $5 / 28 / 11$ & 93 & 5 & 11 & 5 & 8 & 88 \\
\hline CHAL2.0M & $5 / 28 / 11$ & 251 & 17 & 21 & 12 & 19 & 383 \\
\hline CHAL2.0C & $5 / 28 / 11$ & 231 & 15 & 23 & 11 & 14 & 267 \\
\hline CREEK4010 & $5 / 29 / 11$ & 98 & 5 & 10 & 5 & 8 & 79 \\
\hline CREEK4120 & $5 / 29 / 11$ & 94 & 5 & 10 & 5 & 8 & 82 \\
\hline OLDSWT & $6 / 28 / 11$ & 295 & 26 & 61 & 20 & 29 & 395 \\
\hline $\mathrm{CHAL}$ & $6 / 28 / 11$ & 284 & 26 & 56 & 20 & 31 & 427 \\
\hline CHAL2.0C & $6 / 28 / 11$ & 251 & 18 & 50 & 13 & 20 & 418 \\
\hline CHAL2.0M & $6 / 28 / 11$ & 271 & 20 & 55 & 14 & 21 & 435 \\
\hline CESSPE & $6 / 28 / 11$ & 149 & 5 & 17 & 11 & 22 & 115 \\
\hline SPELM & $6 / 28 / 11$ & 58 & 2 & 16 & 1.8 & 3.0 & 20 \\
\hline OLDSWT & $8 / 1 / 11$ & 486 & 36 & 86 & 29 & 29 & 400 \\
\hline $\mathrm{CHAL}$ & $8 / 2 / 11$ & 346 & 28 & 59 & 21 & 32 & 432 \\
\hline CREEK3740 & $8 / 2 / 11$ & 127 & 7 & 24 & 6 & 10 & 109 \\
\hline CREEK3890 & $8 / 2 / 11$ & 144 & 9 & 26 & 8 & 13 & 140 \\
\hline CREEK4010 & $8 / 2 / 11$ & 170 & 11 & 31 & 9 & 15 & 180 \\
\hline CREEK4120 & $8 / 2 / 11$ & 180 & 12 & 32 & 9 & 15 & 191 \\
\hline CESSPE & $8 / 3 / 11$ & 176 & 5 & 17 & 10 & 20 & 115 \\
\hline CHAL2.0C & $8 / 3 / 11$ & 318 & 20 & 31 & 15 & 21 & 436 \\
\hline CHAL2.0M & $8 / 3 / 11$ & 327 & 21 & 31 & 15 & 23 & 448 \\
\hline CREEK6115 & $8 / 3 / 11$ & 182 & 11 & 32 & 9 & 15 & 198 \\
\hline CREEK6150 (D) & $8 / 3 / 11$ & 179 & 11 & 55 & 9 & 15 & 198 \\
\hline CREEK6150 & $8 / 3 / 11$ & 182 & 11 & 56 & 9 & 15 & 196 \\
\hline
\end{tabular}




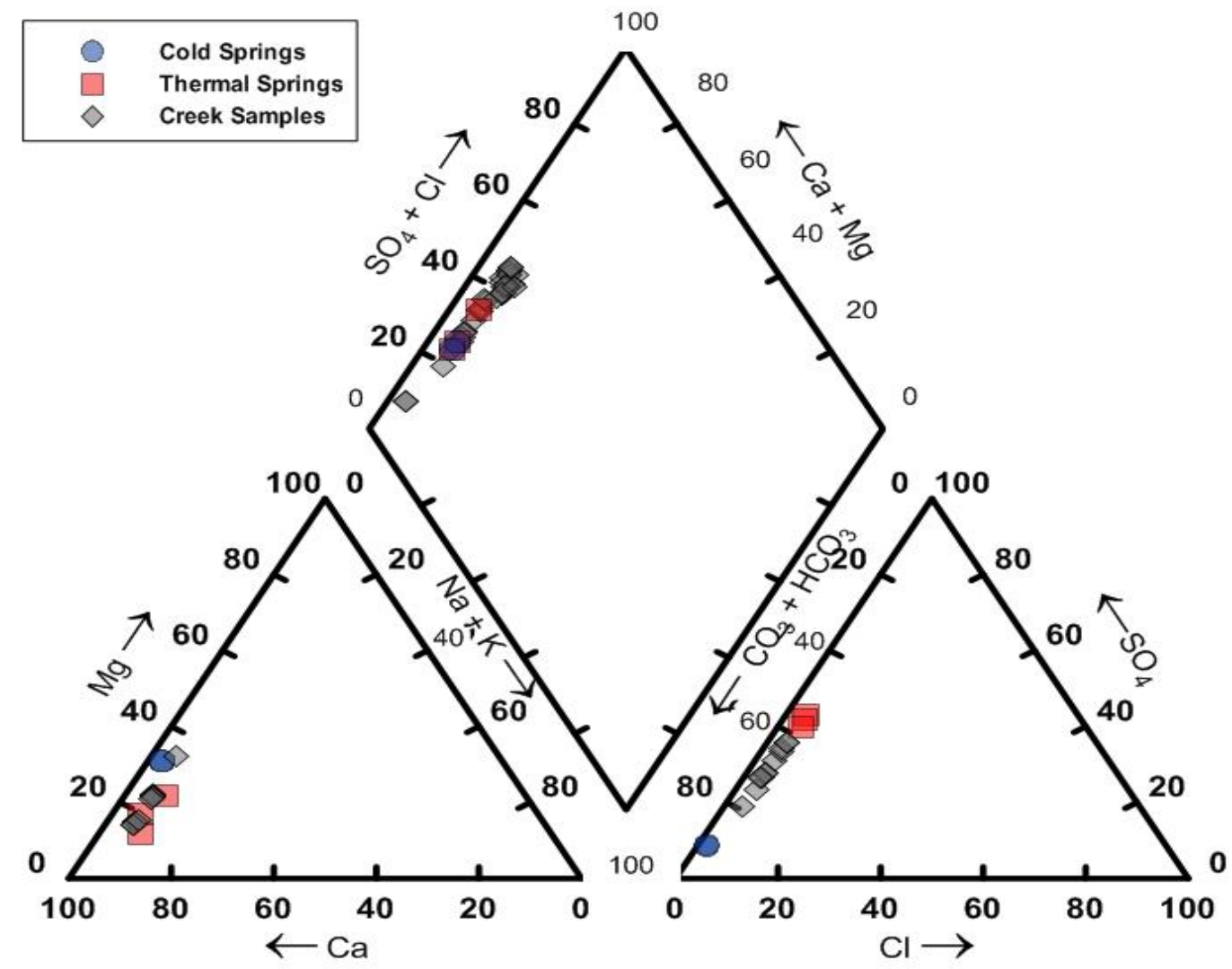

Figure 12 - Piper diagram showing the general relationships of all samples taken. Each point represents as a discrete sample. 
Table 8 - Total organic carbon (TOC), total inorganic carbon (TIC), and total carbon (TC)

\begin{tabular}{lcccccccc}
\hline \hline Sample ID & Date & $(\mathrm{n})$ & $\begin{array}{c}\text { TOC } \\
(\mathrm{mM})\end{array}$ & $\begin{array}{c}\text { TIC } \\
(\mathrm{mM})\end{array}$ & $\begin{array}{c}\text { TC } \\
(\mathrm{mM})\end{array}$ & $\begin{array}{c}\text { RSD } \\
\text { TOC } \%\end{array}$ & $\begin{array}{c}\text { RSD } \\
\text { TIC } \%\end{array}$ & $\begin{array}{c}\text { RSD TC } \\
\%\end{array}$ \\
\hline \hline OLDSWT & $5 / 27 / 11$ & 3 & 0.20 & 6.63 & 6.84 & 25 & 0.1 & 0.8 \\
CHAL2M & $5 / 28 / 11$ & 3 & 0.06 & 4.44 & 4.50 & 11 & 0.9 & 0.8 \\
CREEK6115 & $5 / 28 / 11$ & 3 & 0.09 & 4.30 & 4.40 & 13 & 0.4 & 0.4 \\
WVU-FB & $5 / 29 / 11$ & 3 & 0.07 & 0.06 & 0.13 & 1.1 & 3.4 & 1.0 \\
\hline OLDSWT & $8 / 1 / 11$ & 9 & 7.30 & 8.71 & 16.0 & 6.0 & 2.7 & 1.5 \\
CREEK3740 & $8 / 2 / 11$ & 3 & $<$ DL & 6.00 & 6.00 & $<$ DL & 0.2 & 0.2 \\
CHAL & $8 / 2 / 11$ & 3 & 3.67 & 9.91 & 13.6 & 4.6 & 0.0 & 1.1 \\
CREEK3890 & $8 / 2 / 11$ & 3 & 0.15 & 5.97 & 6.12 & 23 & 0.3 & 0.6 \\
CREEK4010 & $8 / 2 / 11$ & 3 & 0.34 & 7.10 & 7.44 & 12 & 0.6 & 0.8 \\
CREEK4120 & $8 / 2 / 11$ & 3 & 0.62 & 8.03 & 8.66 & 4.7 & 0.2 & 0.0 \\
CHAL2.0M & $8 / 3 / 11$ & 3 & 2.69 & 9.91 & 12.6 & 0.6 & 0.0 & 0.4 \\
CHAL2.0C & $8 / 3 / 11$ & 3 & 4.70 & 9.66 & 14.4 & 3.6 & 0.0 & 1.2 \\
CESSPE & $8 / 3 / 11$ & 3 & 0.42 & 7.99 & 8.41 & 14 & 0.5 & 0.0 \\
CREEK6115 & $8 / 3 / 11$ & 6 & 0.19 & 6.38 & 6.58 & 37 & 5.7 & 6.6 \\
CREEK6150 & $8 / 3 / 11$ & 6 & 0.08 & 5.58 & 5.67 & 29 & 0.3 & 0.3 \\
\hline \hline
\end{tabular}

Notes: RSD=relative standard deviation; $\angle D L$ is below detection limit of the instrument; $\mathrm{n}=$ number of replicates 
CHAL2.0C exceeded the upper measurement limit for TOC at $50 \mathrm{ppm}$, which may indicate erroneous measurements with respect to those samples.

\subsection{Geochemical Calculations}

$\mathrm{H}_{2} \mathrm{CO}_{3}{ }^{*}$ was calculated utilizing Visual Minteq ${ }^{\circledR}$ and compared to the measured $\mathrm{CO}_{2}$ values from the CarboQC ${ }^{\circledR}$ (Table 9). The Visual Minteq ${ }^{\circledR}$ model consistently over-predicted the amount of $\mathrm{CO}_{2}$ in the system in all spring samples with the exception of one OLDSWT sample which was anomalously low and a CHAL sample with 3.0\% difference. The over-predicted values in Minteq ${ }^{\circledR}$ were confirmed by Vesper and Edenborn (2012).

Saturation indices were calculated utilizing Visual Minteq ${ }^{\circledR}$. All minerals modeled were undersaturated in the samples with the exception of aragonite, calcite, and dolomite, which were oversaturated at some sample sites (Table 10). Barite was found to be oversaturated in most samples, but the concentrations of Ba were too low to expect precipitation.

\subsection{Precipitation rates}

\subsubsection{May to August (plate sets $1 A$ \& 1B)}

PWP rates for CHAL and OLDSWT indicated net dissolution; this coincided with an average mass loss observed for the in-situ plates. The rate calculated using the PWP and the rate calculated using field data differed by approximately one order of magnitude (Table 11). This relationship held between the plates that were in situ for $\sim 30$ days (Plate Set $1 \mathrm{~A}$ ) and those in place for $\sim 60$ days (Plate Set 1B); field-measured rates were consistent for the Plate Set $1 \mathrm{~A}$ and Plate Set 1B.

At CREEK4010 and CREEK4120, PWP rates were the inverse of the field-measured rates (Figure 13). Rates were within one order-of-magnitude each other, only with the PWP predicting dissolution and the field rates indicating precipitation. PWP rates for CREEK3740, CREEK3890, and CREEK6115 were within one order-of-magnitude of the field-measured rates and showed precipitation.

\subsubsection{August to September (Plate Set 2)}

OLDSWT was excluded from the data pool for the August to September measurements due to extensive organic growth that yielded erroneous measurements. The PWP rate for CHAL predicted net dissolution and the rates calculated from mass change of the plate showed net precipitation (Table 12). 
Table 9 - Comparison of $\mathrm{CO}_{2}$ values as calculated by Visual Minteq and measured by CarboQC ${ }^{\circledR}$

\begin{tabular}{|c|c|c|c|c|}
\hline Sample ID & Date & $\begin{array}{l}\text { Measured } \\
\mathrm{CO}_{2}(\mathrm{mM})\end{array}$ & $\begin{array}{c}\text { Minteq } \\
\mathrm{CO}_{2}(\mathrm{mM})\end{array}$ & $\begin{array}{c}\text { Percent } \\
\text { Difference }\end{array}$ \\
\hline CHAL & $8 / 10 / 10$ & 10.60 & 13.14 & $21.4 \%$ \\
\hline OLDSWT & $8 / 10 / 10$ & 7.68 & 10.62 & $32.2 \%$ \\
\hline CHAL & $9 / 25 / 10$ & 11.01 & 10.69 & $3.0 \%$ \\
\hline OLDSWT & $9 / 25 / 10$ & 7.82 & 8.13 & $3.9 \%$ \\
\hline SPELM & $9 / 25 / 10$ & na & 0.45 & na \\
\hline CHAL & $11 / 20 / 10$ & na & 9.07 & na \\
\hline OLDSWT & $11 / 20 / 10$ & 7.68 & 8.85 & $14.2 \%$ \\
\hline CESSPE & $11 / 21 / 10$ & 1.87 & 1.89 & $1.1 \%$ \\
\hline CREEK6115 & $11 / 21 / 10$ & na & na & na \\
\hline CREEK3740 & $5 / 26 / 11$ & 0.37 & 0.19 & $64.3 \%$ \\
\hline OLDSWT & $5 / 27 / 11$ & 6.92 & 9.88 & $35.2 \%$ \\
\hline CHAL & $5 / 27 / 11$ & 9.89 & 11.26 & $13.0 \%$ \\
\hline CREEK3890 & $5 / 27 / 11$ & 0.27 & 0.16 & $51.2 \%$ \\
\hline CREEK6115 & $5 / 28 / 11$ & 0.50 & 0.77 & $42.5 \%$ \\
\hline CHAL2.0M & $5 / 28 / 11$ & 5.17 & 8.96 & $53.6 \%$ \\
\hline CHAL2.0C & $5 / 28 / 11$ & 3.72 & 6.05 & $47.7 \%$ \\
\hline CREEK4010 & $5 / 29 / 11$ & 0.77 & 1.15 & $39.6 \%$ \\
\hline CREEK4120 & $5 / 29 / 11$ & 0.77 & 1.52 & $65.5 \%$ \\
\hline SPELM & 6/28/11 & 0.57 & 0.74 & $26.8 \%$ \\
\hline OLDSWT & $6 / 28 / 11$ & 8.95 & 11.49 & $24.9 \%$ \\
\hline CHAL & $6 / 28 / 11$ & 10.36 & 13.44 & $25.9 \%$ \\
\hline CHAL2.0C & $6 / 28 / 11$ & na & 10.84 & na \\
\hline CHAL2.0M & $6 / 28 / 11$ & 6.41 & 8.21 & $24.6 \%$ \\
\hline CESSPE & $6 / 28 / 11$ & 1.60 & 2.22 & $32.5 \%$ \\
\hline OLDSWT & $8 / 1 / 11$ & 7.87 & 4.90 & $46.4 \%$ \\
\hline CHAL & $8 / 2 / 11$ & 10.84 & 13.00 & $18.1 \%$ \\
\hline CREEK3740 & $8 / 2 / 11$ & 0.34 & 0.46 & $32.1 \%$ \\
\hline CREEK3890 & $8 / 2 / 11$ & 0.85 & 1.02 & $19.1 \%$ \\
\hline CREEK4010 & $8 / 2 / 11$ & 1.27 & 2.66 & $70.5 \%$ \\
\hline CREEK4120 & $8 / 2 / 11$ & 1.09 & 2.14 & $65.0 \%$ \\
\hline CHAL2.0C & $8 / 3 / 11$ & 6.46 & 7.45 & $14.3 \%$ \\
\hline CHAL2.0M & $8 / 3 / 11$ & 6.85 & 8.59 & $22.5 \%$ \\
\hline CESSPE & $8 / 3 / 11$ & 1.64 & 2.33 & $34.7 \%$ \\
\hline CREEK6115 & $8 / 3 / 11$ & 0.49 & 0.33 & $39.8 \%$ \\
\hline CREEK6150 & $8 / 3 / 11$ & 0.30 & 0.11 & $91.2 \%$ \\
\hline
\end{tabular}

Note: sample parameters that are not available have the designation na 
Table 10 - Saturation indices for all sample sites where plates were installed

\begin{tabular}{llcccc}
\hline \hline Site & Month & SI $_{\text {ARAGONITE }}$ & SI $_{\text {CALITE }}$ & SI $_{\text {DOLOMITE (Ordered) }}$ & SI $_{\text {GPSSUM }}$ \\
\hline \hline CHAL & May & -0.266 & -0.120 & -0.951 & -0.663 \\
OLDSWT & May & -0.285 & -0.140 & -0.892 & -0.723 \\
CREEK3740 & May & -0.029 & 0.122 & -0.480 & -1.842 \\
CREEK3890 & May & 0.023 & 0.172 & -0.338 & -2.004 \\
CREEK4010 & May & -0.422 & -0.272 & -1.291 & -1.555 \\
CREEK4120 & May & -0.580 & -0.429 & -1.614 & -1.550 \\
CREEK6115 & May & -0.149 & -0.001 & -0.666 & -1.541 \\
\hline CHAL & August & -0.235 & -0.090 & -0.604 & -0.651 \\
OLDSWT & August & 0.020 & 0.020 & 0.144 & -0.749 \\
CREEK3740 & August & 0.264 & 0.415 & 0.331 & -1.381 \\
CREEK3890 & August & 0.050 & 0.199 & -0.089 & -1.256 \\
CREEK4010 & August & -0.188 & -0.040 & -0.528 & -1.126 \\
CREEK4120 & August & -0.053 & 0.095 & -0.277 & -1.087 \\
CREEK6115 & August & 0.726 & 0.873 & 1.284 & -1.073 \\
CREEK6150 & August & 1.169 & 1.317 & 2.425 & -1.108 \\
\hline \hline
\end{tabular}


Table 11 - PWP rates and measured rates for calcite precipitation from plate set 1

\begin{tabular}{|c|c|c|c|c|c|}
\hline \multirow[b]{2}{*}{$\begin{array}{l}\text { Sample } \\
\text { Site }\end{array}$} & \multicolumn{4}{|c|}{ Data from in-situ travertine plates } & \multirow[b]{2}{*}{$\begin{array}{c}\text { Calculated Rate } \\
\text { (Plummer et al., 1978) } \\
\left(\mathrm{mol} \mathrm{cm}^{-2} \mathrm{~s}^{-1}\right)\end{array}$} \\
\hline & $\begin{array}{l}\text { Time } \\
\text { in-situ } \\
\text { (days) }\end{array}$ & $\begin{array}{l}\text { Mass loss or } \\
\text { gain }\left(\mathrm{mol} \mathrm{cm}^{-2}\right)\end{array}$ & $\begin{array}{l}\text { Rate of gain or } \\
\text { loss }\left(\mathrm{mol} \mathrm{cm} \mathrm{cm}^{-2}\right)\end{array}$ & $\begin{array}{c}\text { Standard } \\
\text { Deviation } \\
\left( \pm \mathrm{mol} \mathrm{cm} \mathrm{cm}^{-2} \mathrm{~s}^{-1}\right)\end{array}$ & \\
\hline CHAL & 67 & $-1.04 \mathrm{E}-05$ & $1.80 \mathrm{E}-12$ & & 3.15E-11 \\
\hline $\mathrm{CHAL}$ & 32 & $2.98 \mathrm{E}-06$ & $-1.08 \mathrm{E}-12$ & & $3.15 \mathrm{E}-11$ \\
\hline $\mathrm{CHAL}$ & 32 & $-8.27 \mathrm{E}-06$ & $2.98 \mathrm{E}-12$ & 2.09E-12 & $3.15 \mathrm{E}-11$ \\
\hline OLDSWT & 69 & $-2.11 E-05$ & 3.54E-12 & & 3.93E-11 \\
\hline OLDSWT & 32 & $-9.47 \mathrm{E}-06$ & $3.46 \mathrm{E}-12$ & $5.82 \mathrm{E}-14$ & 3.93E-11 \\
\hline CREEK3740 & 67 & $1.16 \mathrm{E}-04$ & $-2.01 E-11$ & & $-2.56 \mathrm{E}-11$ \\
\hline CREEK3740 & 33 & $1.66 \mathrm{E}-05$ & $-5.83 E-12$ & & $-2.56 \mathrm{E}-11$ \\
\hline CREEK3740 & 33 & $1.47 \mathrm{E}-05$ & $-5.14 \mathrm{E}-12$ & $8.45 \mathrm{E}-12$ & $-2.56 \mathrm{E}-11$ \\
\hline CREEK3890 & 66 & $5.45 E-07$ & $-9.53 E-14$ & & $-4.13 E-11$ \\
\hline CREEK3890 & 32 & $9.27 \mathrm{E}-06$ & $-3.34 \mathrm{E}-12$ & & $-4.13 E-11$ \\
\hline CREEK3890 & 32 & 3.01E-06 & $-1.09 \mathrm{E}-12$ & $1.66 \mathrm{E}-12$ & $-4.13 E-11$ \\
\hline CREEK4010 & 65 & $2.10 \mathrm{E}-05$ & $-3.73 E-12$ & & $5.50 \mathrm{E}-11$ \\
\hline CREEK4010 & 30 & $2.63 \mathrm{E}-05$ & $-1.01 \mathrm{E}-11$ & & $5.50 \mathrm{E}-11$ \\
\hline CREEK4010 & 30 & $9.79 \mathrm{E}-06$ & $-3.76 \mathrm{E}-12$ & $3.66 \mathrm{E}-12$ & $5.50 \mathrm{E}-11$ \\
\hline CREEK4120 & 65 & 4.50E-06 & $-7.98 E-13$ & & 8.06E-11 \\
\hline CREEK4120 & 30 & $2.85 \mathrm{E}-05$ & $-1.09 \mathrm{E}-11$ & & 8.06E-11 \\
\hline CREEK4120 & 30 & $1.54 \mathrm{E}-05$ & $-5.90 \mathrm{E}-12$ & $5.50 \mathrm{E}-12$ & 8.06E-11 \\
\hline CREEK6115 & 67 & 3.35E-05 & $-5.81 E-12$ & & $-3.79 E-12$ \\
\hline CREEK6115 & 31 & $2.18 \mathrm{E}-05$ & $-8.15 E-12$ & & $-3.79 \mathrm{E}-12$ \\
\hline CREEK6115 & 31 & $1.13 \mathrm{E}-05$ & $-4.23 E-12$ & $1.97 \mathrm{E}-12$ & $-3.79 \mathrm{E}-12$ \\
\hline
\end{tabular}

Note: bold samples denote those plates that were in-situ for $>60$ days 


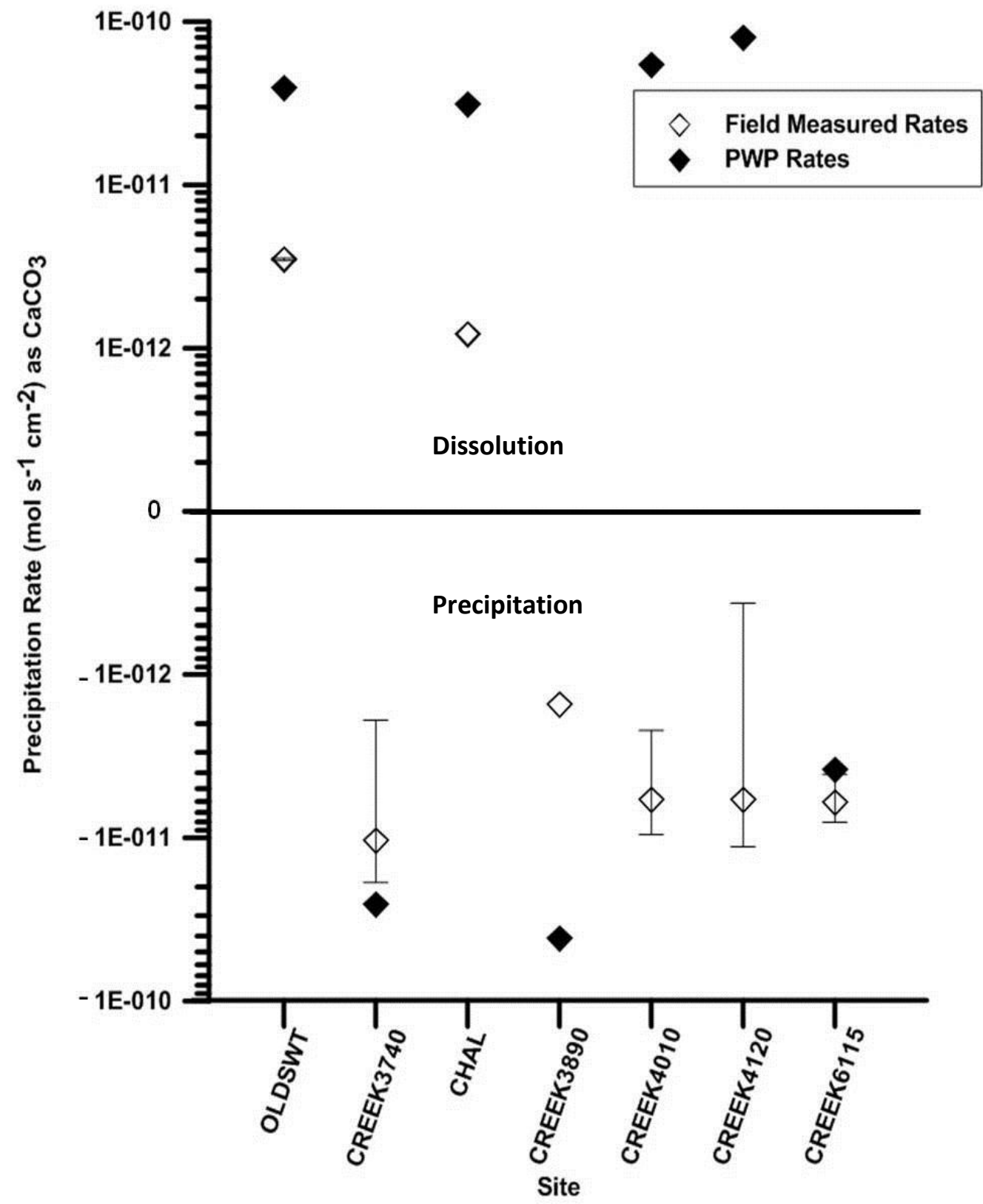

Figure 13 - Calcite precipitation rates as calculated via the PWP equation and field-measured rates for plates, May, 2011 to July, 2011. Standard deviations are given for the fieldmeasured rates. 
Table 12 - PWP rates and measured rates for calcite precipitation from plate set 2

\begin{tabular}{|c|c|c|c|c|c|}
\hline \multirow[b]{2}{*}{$\begin{array}{l}\text { Sample } \\
\text { Site }\end{array}$} & \multicolumn{4}{|c|}{ Data from in-situ travertine plates } & \multirow{2}{*}{$\begin{array}{c}\text { Calculated Rate } \\
\text { (Plummer et al. 1978) } \\
\left(\mathrm{mol} \mathrm{cm}^{-2} \mathrm{~s}^{-1}\right)\end{array}$} \\
\hline & $\begin{array}{l}\text { Time } \\
\text { in-situ } \\
\text { (days) } \\
\end{array}$ & $\begin{array}{l}\text { Mass loss or } \\
\text { gain }\left(\mathrm{mol} \mathrm{cm}{ }^{-2}\right)\end{array}$ & $\frac{\text { Rate of gain or loss }}{\left(\mathrm{mol} \mathrm{cm} \mathrm{cm}^{-2}\right)}$ & $\begin{array}{c}\text { Standard } \\
\text { Deviation } \\
\left( \pm \mathrm{mol} \mathrm{cm}^{-2} \mathrm{~s}^{-1}\right) \\
\end{array}$ & \\
\hline CHAL & 31 & $-5.59 \mathrm{E}-07$ & $2.09 \mathrm{E}-13$ & & $9.93 \mathrm{E}-12$ \\
\hline CHAL & 31 & $2.21 \mathrm{E}-06$ & $-8.27 E-13$ & & $9.93 \mathrm{E}-12$ \\
\hline CHAL & 31 & $-2.20 \mathrm{E}-06$ & $8.24 \mathrm{E}-13$ & & $9.93 \mathrm{E}-12$ \\
\hline CHAL & 31 & $5.50 \mathrm{E}-06$ & $-2.05 \mathrm{E}-12$ & & $9.93 \mathrm{E}-12$ \\
\hline CHAL & 31 & $-3.49 \mathrm{E}-06$ & $1.30 \mathrm{E}-12$ & & $9.93 \mathrm{E}-12$ \\
\hline CHAL & 31 & $3.81 \mathrm{E}-06$ & $-1.42 \mathrm{E}-12$ & $1.32 \mathrm{E}-12$ & $9.93 \mathrm{E}-12$ \\
\hline CREEK3740 & 31 & $2.35 \mathrm{E}-04$ & $-8.79 \mathrm{E}-11$ & & $-1.78 \mathrm{E}-10$ \\
\hline CREEK3740 & 31 & $2.12 \mathrm{E}-04$ & $-7.91 \mathrm{E}-11$ & & $-1.78 \mathrm{E}-10$ \\
\hline CREEK3740 & 31 & $1.85 \mathrm{E}-04$ & $-6.93 E-11$ & & $-1.78 \mathrm{E}-10$ \\
\hline CREEK3740 & 31 & $2.21 \mathrm{E}-04$ & $-8.27 E-11$ & & $-1.78 \mathrm{E}-10$ \\
\hline CREEK3740 & 31 & $2.21 \mathrm{E}-04$ & $-8.26 \mathrm{E}-11$ & & $-1.78 \mathrm{E}-10$ \\
\hline CREEK3740 & 31 & $2.12 \mathrm{E}-04$ & $-7.93 \mathrm{E}-11$ & $6.20 \mathrm{E}-12$ & $-1.78 \mathrm{E}-10$ \\
\hline CREEK3890 & 31 & $5.34 \mathrm{E}-06$ & $-1.99 \mathrm{E}-12$ & & $-8.74 \mathrm{E}-11$ \\
\hline CREEK3890 & 31 & 5.30E-06 & $-1.98 \mathrm{E}-12$ & & $-8.74 \mathrm{E}-11$ \\
\hline CREEK3890 & 31 & $4.92 \mathrm{E}-06$ & $-1.83 \mathrm{E}-12$ & & $-8.74 \mathrm{E}-11$ \\
\hline CREEK3890 & 31 & $1.41 \mathrm{E}-07$ & $-5.26 \mathrm{E}-14$ & & $-8.74 \mathrm{E}-11$ \\
\hline CREEK3890 & 31 & 4.95E-06 & $-1.84 \mathrm{E}-12$ & & $-8.74 \mathrm{E}-11$ \\
\hline CREEK3890 & 31 & 4.25E-06 & $-1.59 \mathrm{E}-12$ & $7.47 \mathrm{E}-13$ & $-8.74 \mathrm{E}-11$ \\
\hline CREEK4010 & 31 & $8.38 \mathrm{E}-06$ & $-3.15 E-12$ & & $-1.43 \mathrm{E}-11$ \\
\hline CREEK4010 & 31 & 8.85E-06 & $-3.33 E-12$ & & $-1.43 E-11$ \\
\hline CREEK4010 & 31 & $8.08 \mathrm{E}-06$ & $-3.04 \mathrm{E}-12$ & & $-1.43 \mathrm{E}-11$ \\
\hline CREEK4010 & 31 & 1.07E-05 & $-4.02 \mathrm{E}-12$ & & $-1.43 \mathrm{E}-11$ \\
\hline CREEK4010 & 31 & $6.79 \mathrm{E}-06$ & $-2.55 \mathrm{E}-12$ & & $-1.43 \mathrm{E}-11$ \\
\hline CREEK4010 & 31 & $1.16 \mathrm{E}-05$ & $-4.38 \mathrm{E}-12$ & $6.71 \mathrm{E}-13$ & $-1.43 \mathrm{E}-11$ \\
\hline CREEK4120 & 31 & $1.24 \mathrm{E}-05$ & $-4.65 E-12$ & & $-7.02 \mathrm{E}-11$ \\
\hline CREEK4120 & 31 & $1.61 \mathrm{E}-05$ & $-6.04 \mathrm{E}-12$ & & $-7.02 \mathrm{E}-11$ \\
\hline CREEK4120 & 31 & 4.69E-06 & $-1.76 \mathrm{E}-12$ & & $-7.02 E-11$ \\
\hline CREEK4120 & 31 & $1.92 \mathrm{E}-06$ & $-7.22 \mathrm{E}-13$ & & $-7.02 E-11$ \\
\hline CREEK4120 & 31 & $6.90 \mathrm{E}-06$ & $-2.59 \mathrm{E}-12$ & & $-7.02 E-11$ \\
\hline CREEK4120 & 31 & $1.20 \mathrm{E}-05$ & $-4.52 \mathrm{E}-12$ & $2.01 \mathrm{E}-12$ & $-7.02 \mathrm{E}-11$ \\
\hline CREEK6115 & 32 & $9.85 \mathrm{E}-05$ & $-3.55 \mathrm{E}-11$ & & $-7.16 \mathrm{E}-10$ \\
\hline CREEK6115 & 32 & 1.17E-04 & $-4.22 \mathrm{E}-11$ & & $-7.16 \mathrm{E}-10$ \\
\hline CREEK6115 & 32 & $1.20 \mathrm{E}-04$ & $-4.33 E-11$ & & $-7.16 \mathrm{E}-10$ \\
\hline CREEK6115 & 32 & $1.08 \mathrm{E}-04$ & $-3.90 \mathrm{E}-11$ & & $-7.16 \mathrm{E}-10$ \\
\hline CREEK6115 & 32 & $1.08 \mathrm{E}-04$ & $-3.90 E-11$ & & $-7.16 \mathrm{E}-10$ \\
\hline CREEK6115 & 32 & $1.20 \mathrm{E}-04$ & $-4.31 \mathrm{E}-11$ & $3.05 \mathrm{E}-12$ & $-7.16 \mathrm{E}-10$ \\
\hline
\end{tabular}

Note: OLDSWT samples are not included in table 
In all of the stream samples, both precipitation rate calculations indicated net precipitation (Figure 14). Rates were within one order-of-magnitude of each other, with the PWP rates being the larger magnitude of the two.

Plates were installed at CREEK6150, however, the precipitate was granular in nature and during recovery significant quantities were lost due to the unconsolidated precipitation (Figure 15). Therefore, weight measurements were not taken.

\subsubsection{Replicates and deviation}

Replicates were done in sets of 3 for the first round of plates and in sets of 6 for the second round of plates in May, 2011 and August, 2011, respectively. The plate set deployed in May had an average overall RSD of 79\%. The CHAL plate set had two plates with dissolution and one plate with precipitation which inflated the overall deviation of the May, 2011 plate set; the deviation between the CHAL plates was $170 \%$.

Rates calculated from the plate set deployed in August, 2011 had an average overall RSD of $91 \%$. As in the May, 2011 plate set, CHAL introduced the most variability. However, the average RSD for stream plate samples in August was $29 \%$ whereas in May the average RSD was 64\%. The lower RSD in the August, 2011 samples is likely a product of the larger sample size, which constrained the variance to a greater degree.

\subsection{Plate analysis}

SEM analysis revealed algae on the plates from CREEK4010 and CREEK4120 (Figure 16); the algae decayed when exposed to the electron beam. Diatoms were also found to colonize all of the plates in the stream (Figure 17). Calcite scalenohedrons were found on the plates installed at CREEK3740 and CREEK6115. The scalenohedron had pores about $10 \mu \mathrm{m}$ in diameter (Figure 18). These micro-pores suggest outgassing of $\mathrm{CO}_{2}$ at the crystal surface during precipitation, resulting in voids as calcite precipitated around $\mathrm{CO}_{2}$ bubbles (Aquilano et al., 2003; Pentecost, 2005). Crystals showed signs of dissolution and the crystal faces did not terminate regularly. Quartz grains were also found on the surface of some plates (Figure 19); quartz accounted for $<1 \%$ of surface area and appeared to be detrital. Radial-acicular crystals of a sulfate mineral were found on the plate from CREEK3890; the mineral showed moderate contrast to the substrate (Figure 20). EDS showed the crystals contained $54 \% \mathrm{SO}_{3}$ and $39 \% \mathrm{CaO}$ with other minor oxides. This composition tentatively suggests gypsum $\left(\mathrm{CaSO}_{4}\right)$; the acicular 


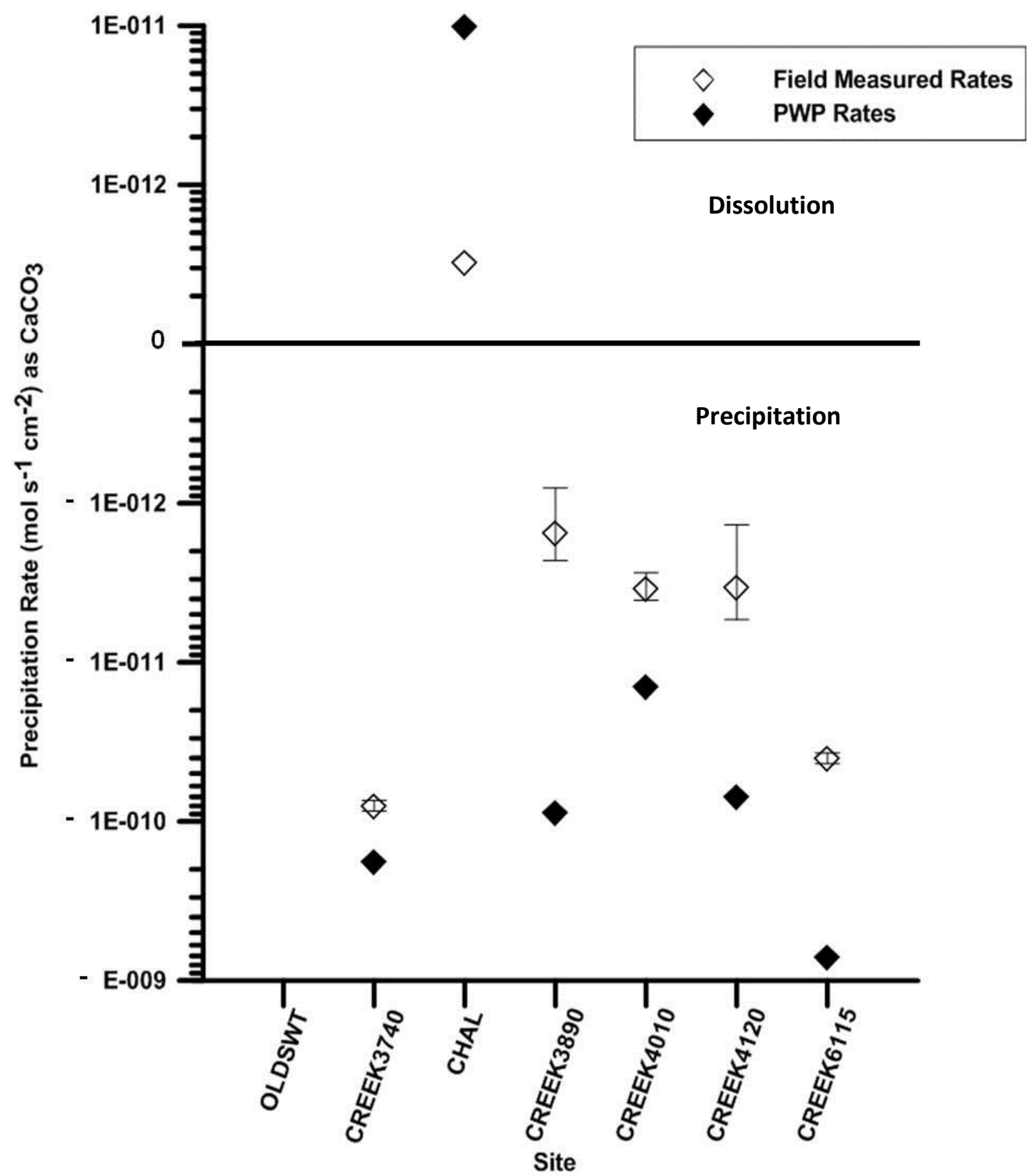

Figure 14 - Calcite precipitation rates as calculated via the PWP equation and field-measured rates for August to September, 2011. Standard deviations are given for the fieldmeasured rates. 

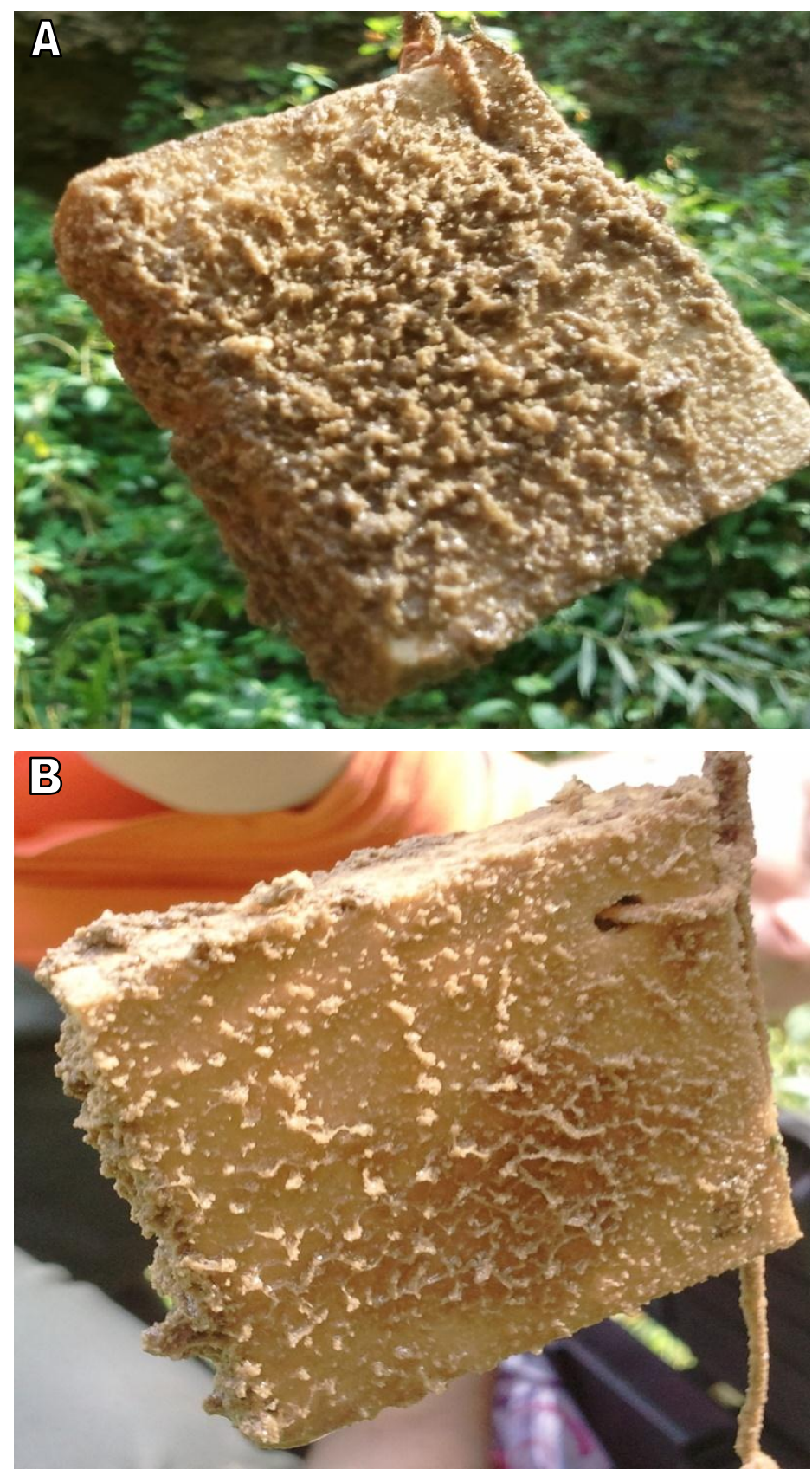

Figure 15 - Plates recovered from CREEK6150, below Sawmill Falls, encrusted in loose mineral precipitate. During recovery precipitate was lost and thus the plates were excluded from measurement. 


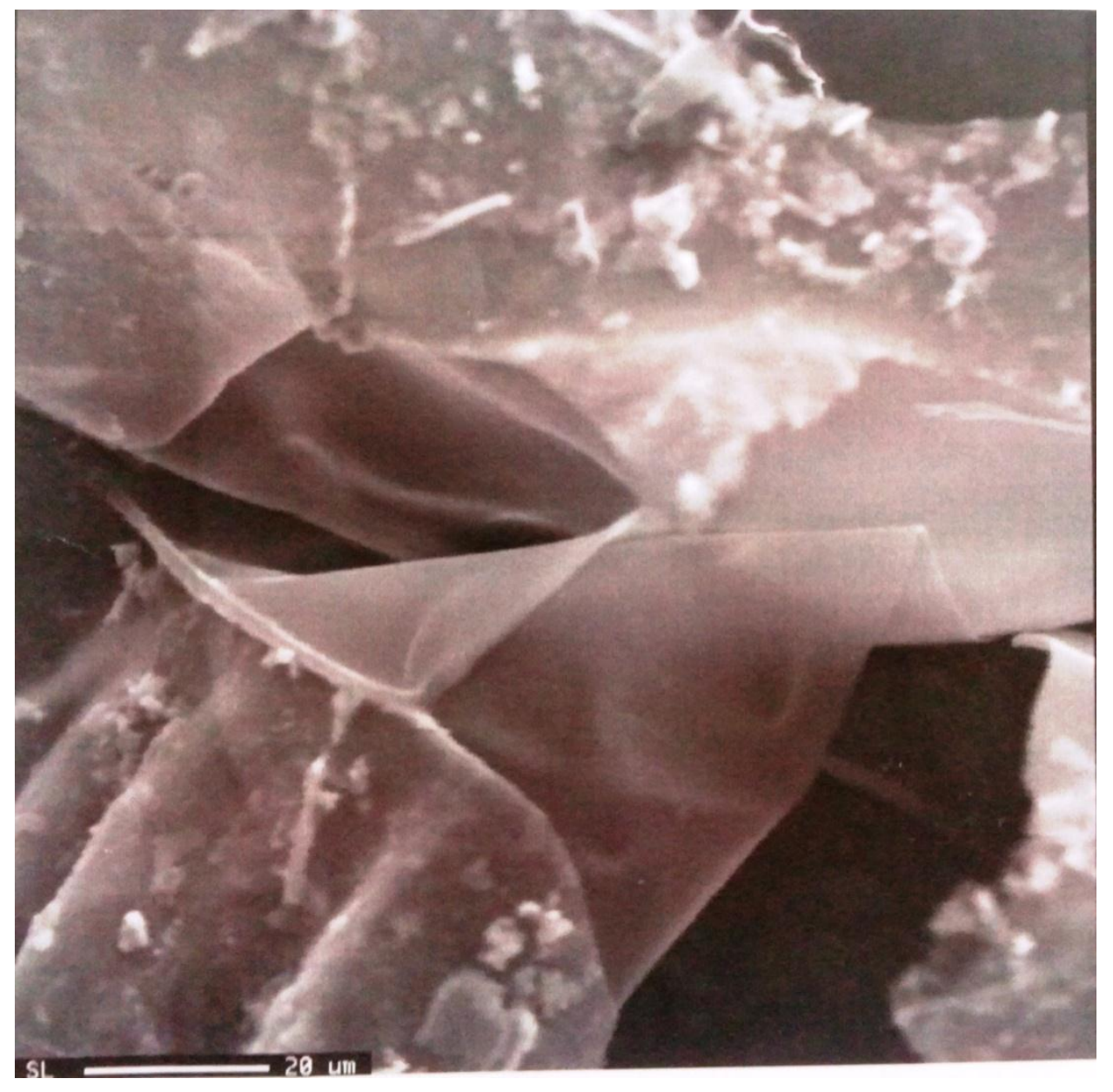

Figure 16 - Algae growing on travertine plate surface of a plate installed at CREEK4120. 

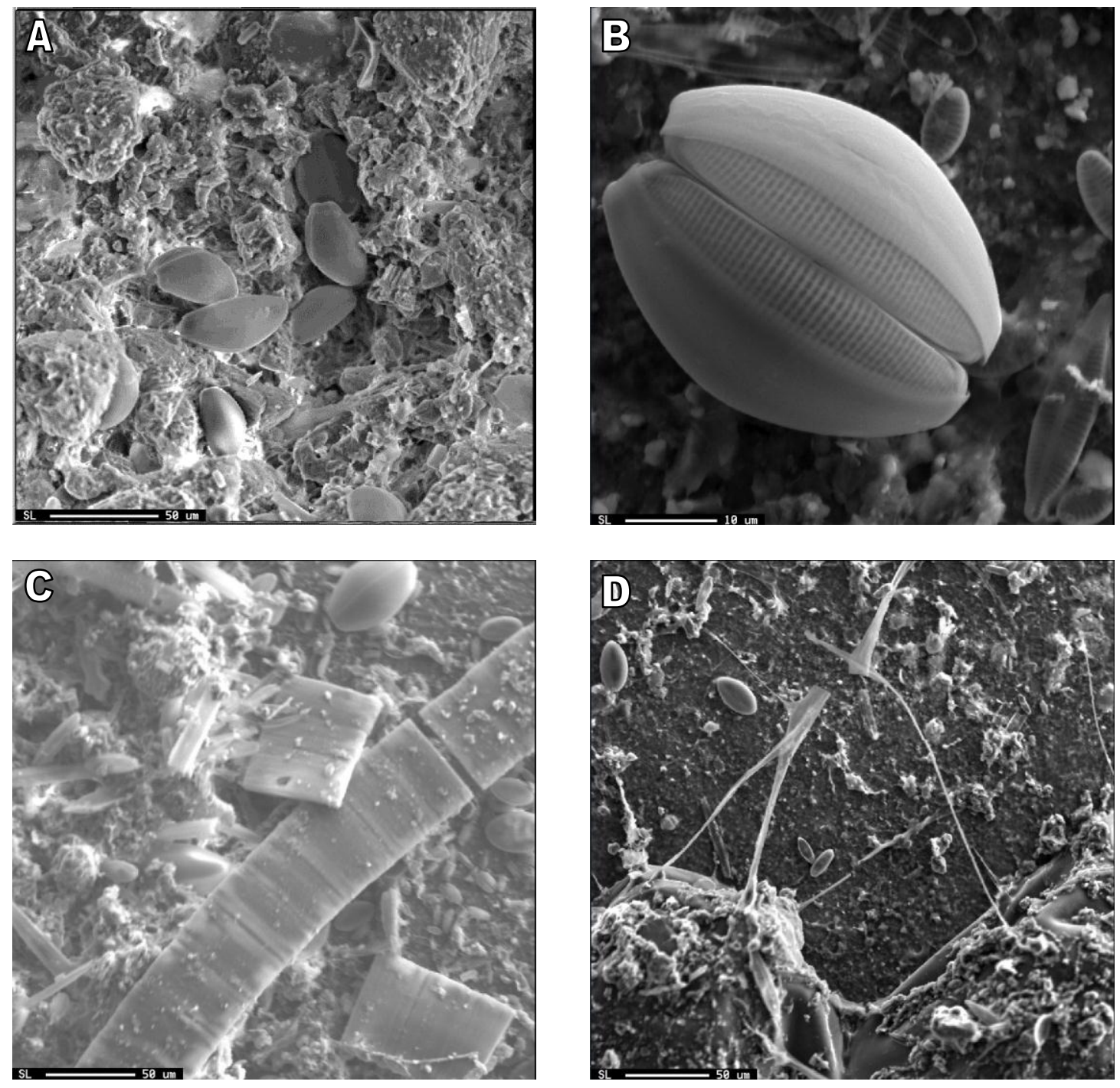

Figure 17 - (A) Diatoms in matrix of precipitate at CREEK3740, (B) diatom from CREEK3890, (C) broken remains of filamentous diatom in precipitate from CREEK4010, and (D) algae growth in the lower part of the picture with diatoms in the upper portions from plate at CREEK4120. 

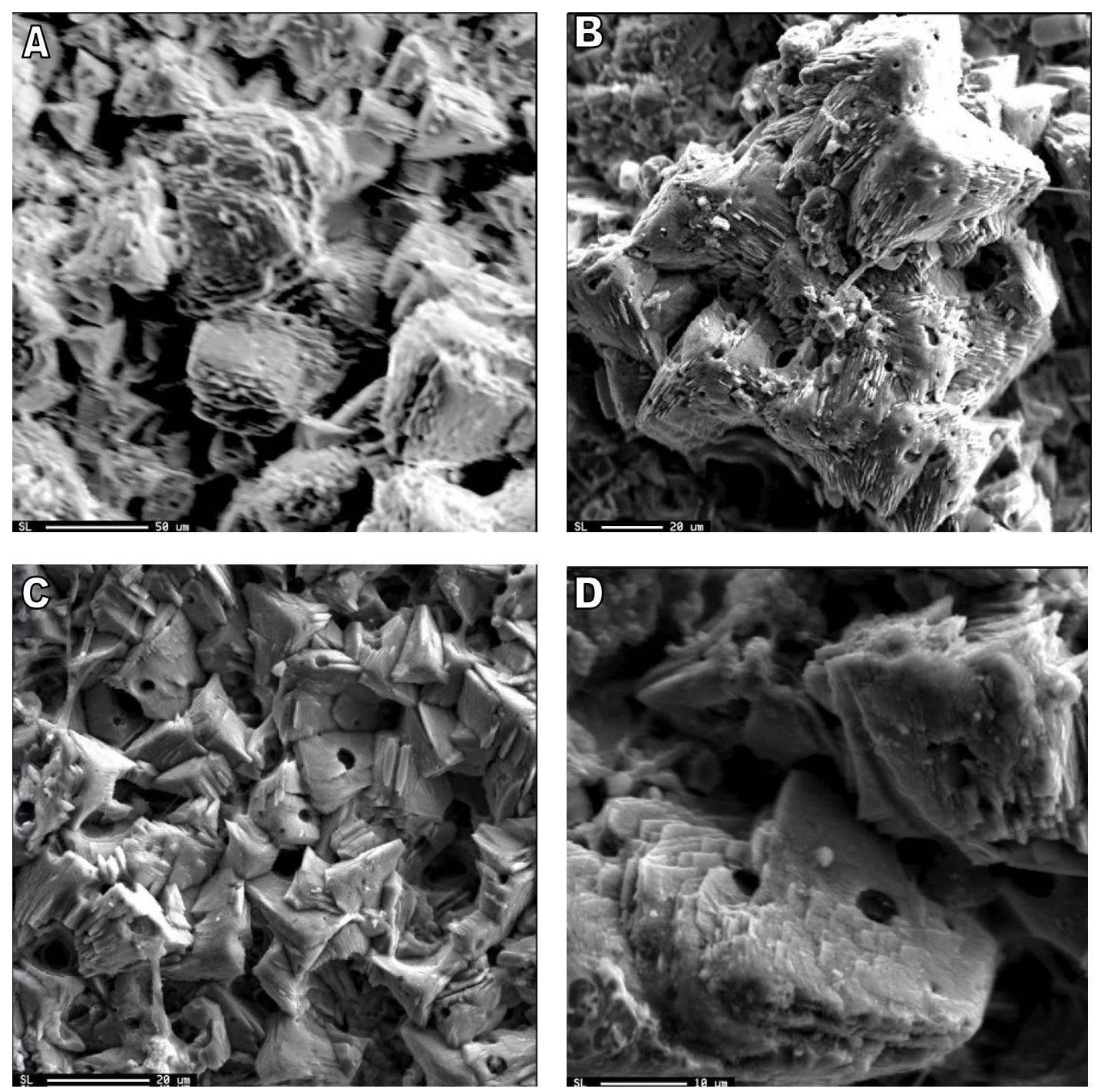

Figure 18 - (A) Calcite scalehedra with growth faces from precipitate at CREEK3740, (B) incomplete calcite scalehedra from precipitate at CREEK6115, (C) stacked calcite scalehedra from precipitate at CREEK6115, and (D) zoomed view of growth faces and pores on calcite scalehedra from precipitate at CREEK6115. 


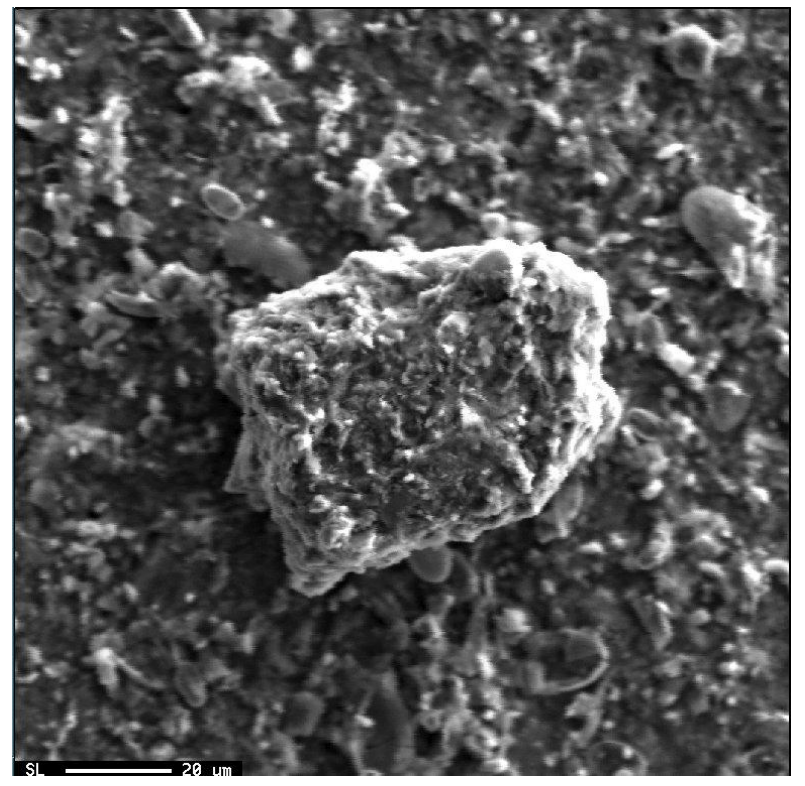

Figure 19 - Detrital quartz grain from plate at CREEK3890. Grain may have a clay coating as evidenced by the highly irregular faces. 

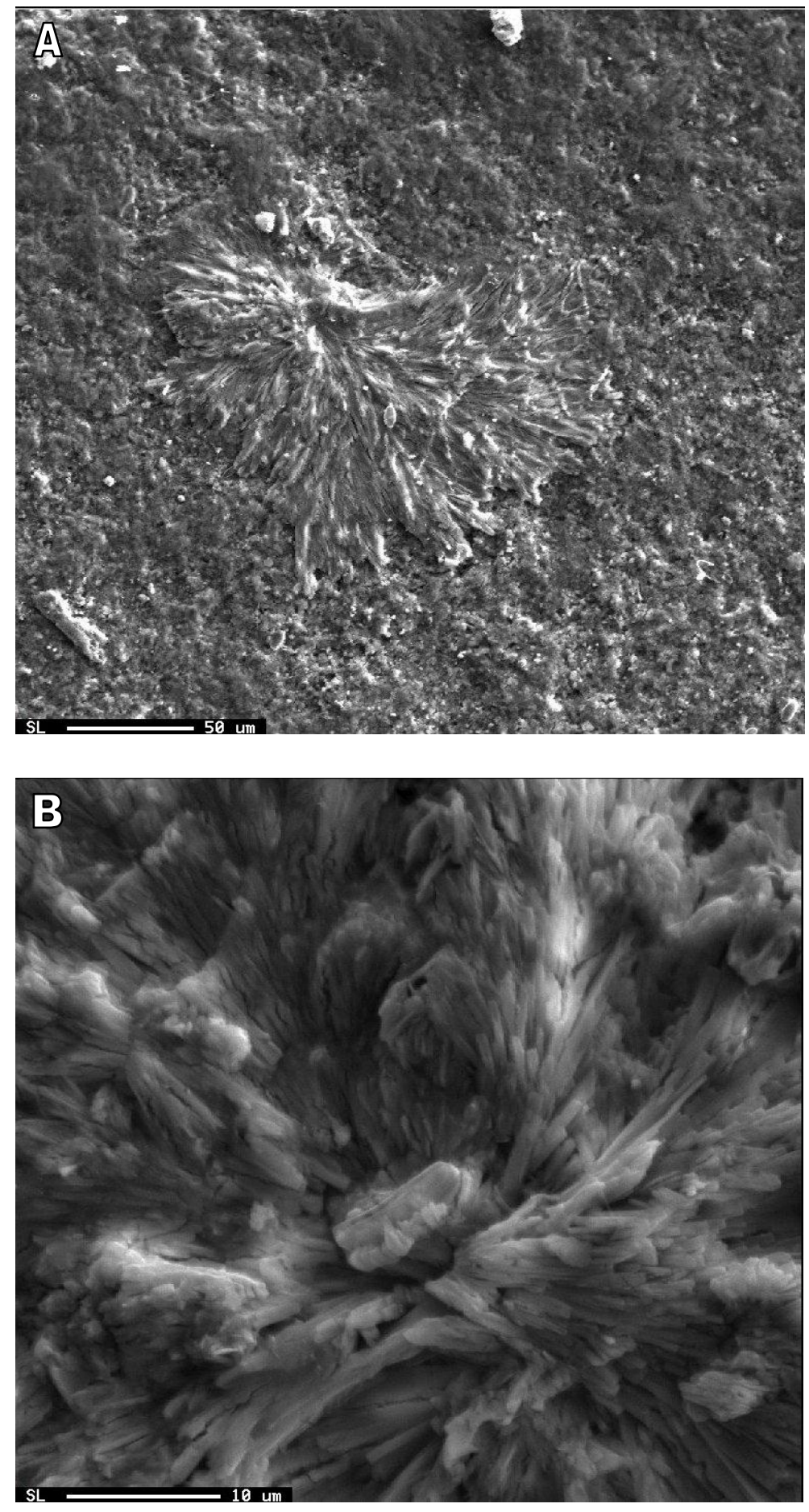

Figure 20 - (A) Overall view of sulfur mineral found on plate from CREEK3890 and (B) closer view of sulfur mineral showing the radial pattern at the center of the crystal. Mineral is likely selenite $\left(\mathrm{CaSO}_{4}{ }^{*} 2 \mathrm{H}_{2} \mathrm{O}\right)$ due to radial nature and sulfur content. 
nature suggests that it is likely of the selenite variety (Personal Communication, Robert Behling, January, 2012).

Light microscopy revealed the presence of midge larvae cases on the surface of the plates (Figure 21). These structures were around $5 \mathrm{~mm}$ in length and appeared to have detrital matrices consisting of calcite spar and quartz. Algal growth was extensive on mineral precipitation plates from CREEK4010 and CREEK4120 (Figure 22). Mineral crystals existed in large clusters on CREEK6150 plates, appearing as merged scalahedrons (Figure 23).

XRF-F analysis was performed on precipitate on plates from CREEK3740, CREEK6115, and CREEK6150, along with a sample of travertine, CESSPE-Trav, from near CESSPE (Table 13). In all samples the majority of the precipitate mass, $>88 \%$, was $\mathrm{CaO}$ and combustible materials that were LOI. Silica oxides were found at or above $3 \%$ of total mass in all samples. The total mass accounted for after combustion was $>96 \%$ in all samples.

Total carbon content of the precipitates was measured for from CREEK3740, CREEK6150, and CESSPE-Trav (Table 13). Analysis was not performed on CREEK6115 due to a lack of mass for the procedure. All samples contained between $11.2 \%$ and $11.5 \%$ carbon as weight \%. 

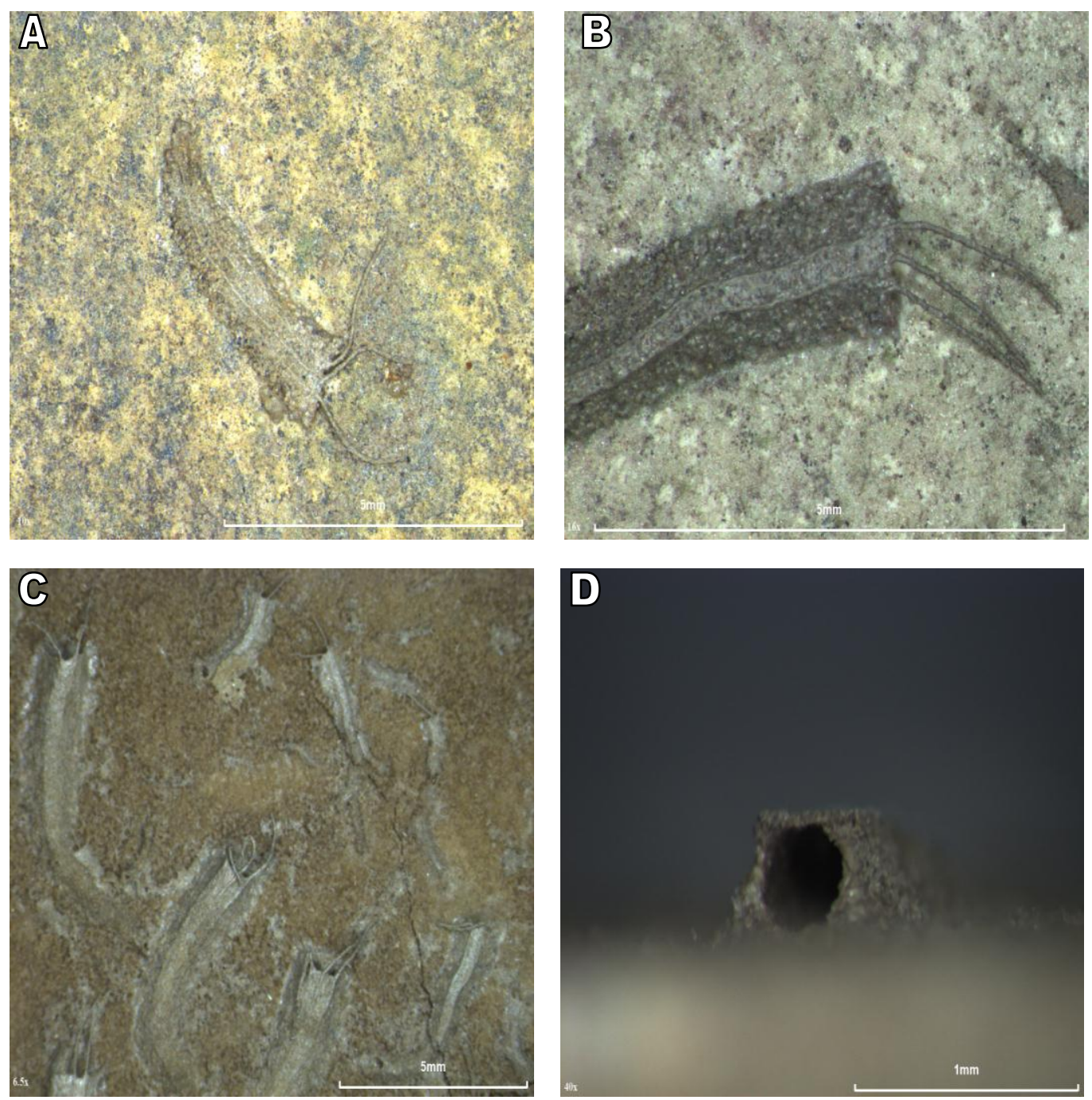

Figure 21 - (A) Midge larvae case from CREEK3740 in May, (B) midge larvae casing from CREEK4120 in May, (C) midge larvae casings from CREEK3740 in August, (D) side view of midge larvae casing. 

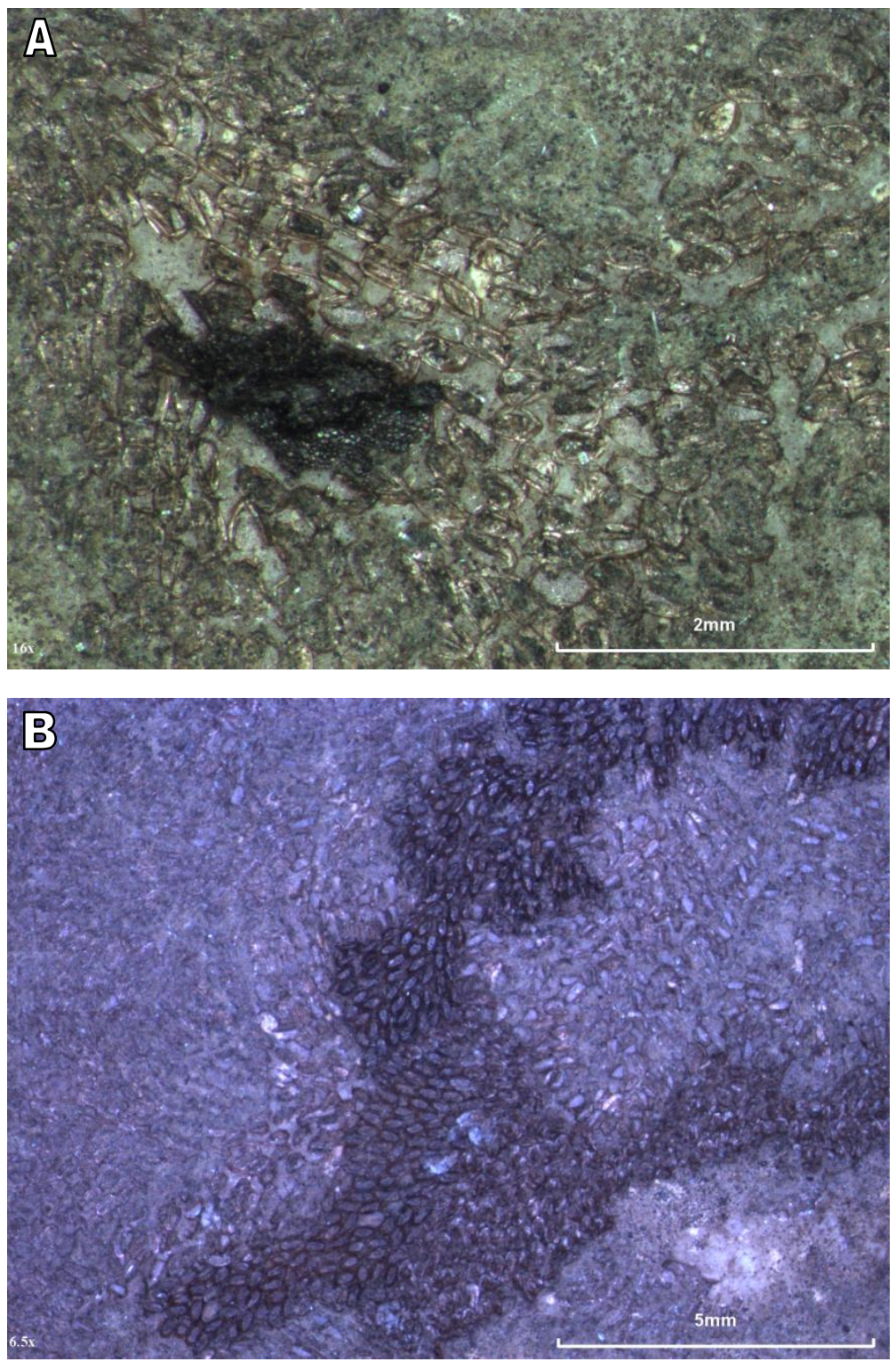

Figure 22 - Images of algal growth from May 2011 at (A) CREEK4010 and (B) CREEK4120. 

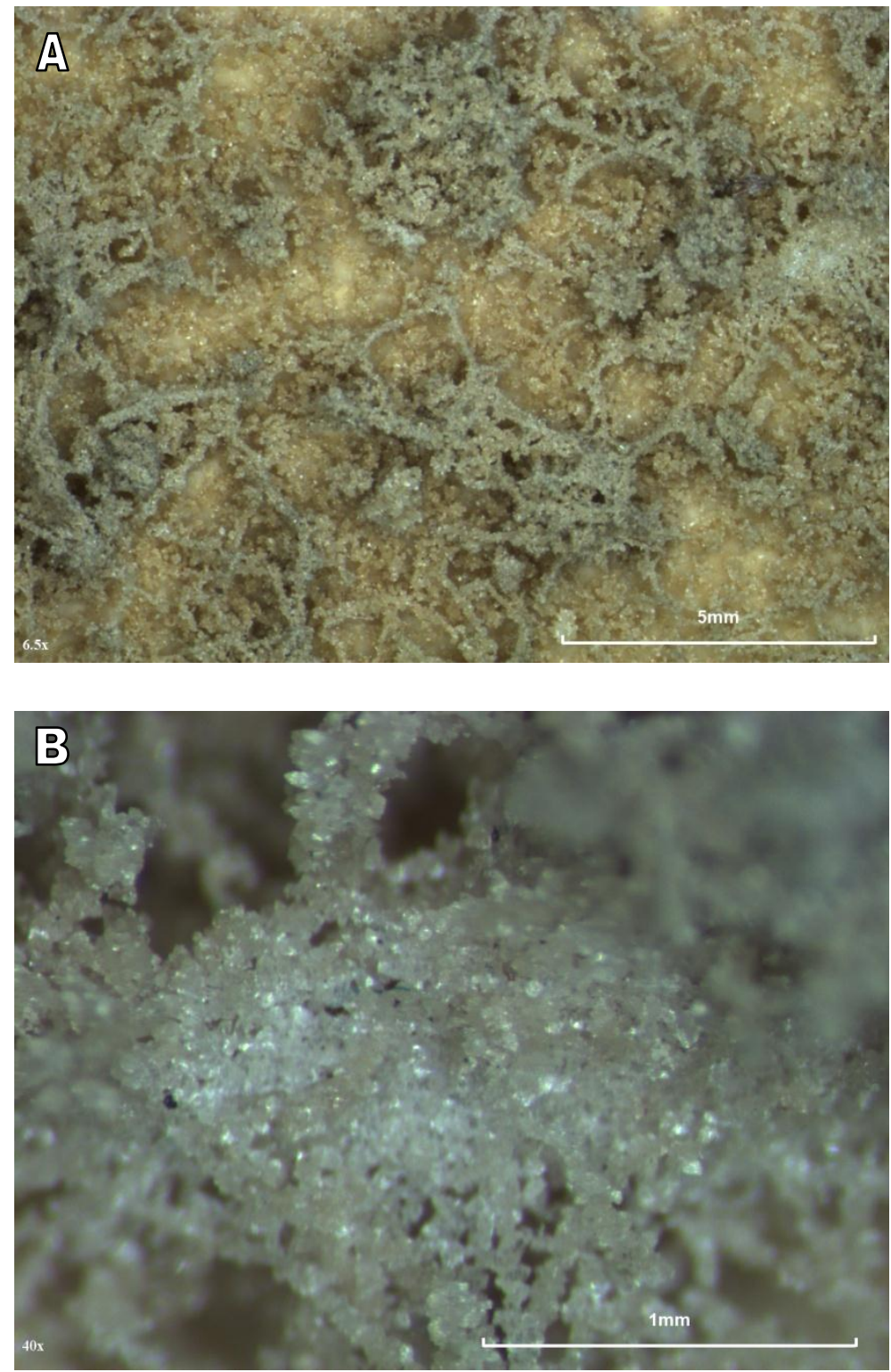

Figure 23 - Crystals found on precipitation plates from CREEK6150 at (A) at 6.5X magnification and (B) at 40X magnification. Crystals appear to be calcite scalahedrons. 
Table 13 - XRF-Fusion data from precipitates

\begin{tabular}{lllccc}
\hline \hline Analyte & $\begin{array}{l}\text { Detection } \\
\text { Limit }\end{array}$ & $\begin{array}{l}\text { CESSPE- } \\
\text { Trav }\end{array}$ & CREEK3740 & CREEK6150 & CREEK6115 \\
\hline \hline $\mathrm{SiO}_{2}$ & 0.01 & 4.00 & 7.13 & 4.79 & 3.49 \\
$\mathrm{Al}_{2} \mathrm{O}_{3}$ & 0.01 & 1.10 & 1.39 & 0.66 & 0.61 \\
$\mathrm{Fe}_{2} \mathrm{O}_{3}$ & 0.01 & 0.50 & 0.48 & 0.47 & 0.30 \\
$\mathrm{MnO}$ & 0.01 & 0.04 & 0.15 & 0.12 & 0.05 \\
$\mathrm{MgO}$ & 0.01 & 0.37 & 0.45 & 0.41 & 0.47 \\
$\mathrm{CaO}$ & 0.01 & 51.1 & 47.7 & 50.0 & 51.4 \\
$\mathrm{Na}_{2} \mathrm{O}$ & 0.01 & 0.03 & 0.04 & $<\mathrm{DL}$ & 0.02 \\
$\mathrm{~K}_{2} \mathrm{O}$ & 0.01 & 0.06 & 0.07 & 0.01 & 0.03 \\
$\mathrm{TiO}_{2}$ & 0.01 & 0.08 & 0.11 & 0.06 & 0.06 \\
$\mathrm{P}_{2} \mathrm{O}_{5}$ & 0.01 & 0.04 & 0.07 & 0.06 & 0.04 \\
$\mathrm{LOI}^{\mathrm{O}}$ & & 41.8 & 40.9 & 40.1 & 42.5 \\
\hline Total: & & 99.24 & 98.44 & 96.72 & 98.95 \\
\hline \hline
\end{tabular}

Note: all analytes expressed as \% relative to total weight; detection limit expressed as \% relative to total weight 
Table 14 - Total carbon content of solid precipitate expressed as $\mathrm{CO}_{2}$

\begin{tabular}{lcc}
\hline \hline Sample ID & $\mathrm{CO}_{2} \%$ & C- Total \% \\
\hline \hline CESSPE-Trav & 40.9 & 11.2 \\
CREEK3740 & 40.1 & 10.9 \\
CREEK6150 & 41.0 & 11.2 \\
\hline \hline
\end{tabular}

Note: all mass is relative to the total mass of the sample before

combustion 


\subsection{Discussion}

\subsection{Water sources in the geologic framework}

\subsubsection{Water source}

Three distinct groupings of water can be identified from temperature and $\mathrm{CO}_{2}$ concentrations in the study area (Figure 24). While these waters have differing chemistries, the cold spring and stream chemistry are functions of the local lithology and meteoric input. The stream chemistry is clearly dependent on spring input as well; however, meteoric recharge and the resulting change in discharge plays a large role in total ionic strength (Figure 25).

CESSPE is anomalous in the study area in that it is cold and is dominated by carbonate chemistry (moderate alkalinity and neutral $\mathrm{pH}$ ) in conjunction with high $\mathrm{H}_{2} \mathrm{~S}$ and the precipitation of gypsum. Alkalinity is elevated in CESSPE from the chemotrophic oxidation of $\mathrm{H}_{2} \mathrm{~S}$, resulting in the precipitation of gypsum on the cave walls (Engel et al., 2001; Hubbard et al., 1990). The reaction proceeds as follows:

$$
2 \mathrm{H}_{2} \mathrm{~S}+\mathrm{O}_{2} \longrightarrow 2 \mathrm{~S}^{\circ}+\mathrm{H}_{2} \mathrm{O}
$$

followed by the oxidation of sulfur to sulfate:

$$
2 \mathrm{~S}^{\circ}+3 \mathrm{O}_{2}+2 \mathrm{H}_{2} \mathrm{O} \longrightarrow 4 \mathrm{H}^{+}+2 \mathrm{SO}_{4}{ }^{2-}
$$

and the dissolution of calcite and formation of gypsum:

$$
\mathrm{CaCO}_{3}+\mathrm{H}^{+}+\mathrm{SO}_{4}^{-2} \longrightarrow \mathrm{CaSO}_{4}+\mathrm{HCO}_{3}^{-}
$$

It has been suggested that the unique chemistry of the water is derived from shallow oil-field brines in the underlying strata that release $\mathrm{H}_{2} \mathrm{~S}$ via the local faults and fractures (Engel et al., 2001; Hubbard et al., 1990). The high sulfate of underlying units, previous petroleum recovery, and faulted nature of the region would certainly allow for the geochemistry observed.

The temperatures of the thermal springs correlates with a depth of approximately 1.5 $\mathrm{km}$ to a maximum of $3 \mathrm{~km}$; it is likely that the springs circulate to no greater depth and rise rapidly to the surface (Goldscheider et al., 2010; Herman et al., 1990; Hobba et al., 1979; Hubbard and Herman, 1991; Perry et al., 1979). The elevated $\mathrm{CO}_{2}$ and temperatures support a flow system that is confined, equilibrates thermally at depth, and rises rapidly to maintain elevated temperatures, likely along with the St. Clair thrust fault. It is also possible that the system is warmer at depth and the waters rise slowly, cooling over time; this would indicate that we are measuring the minimum depth and that the system could be deeper. Tritium data suggest that the waters have a residence time $>20$ years, which would be sufficient time to 


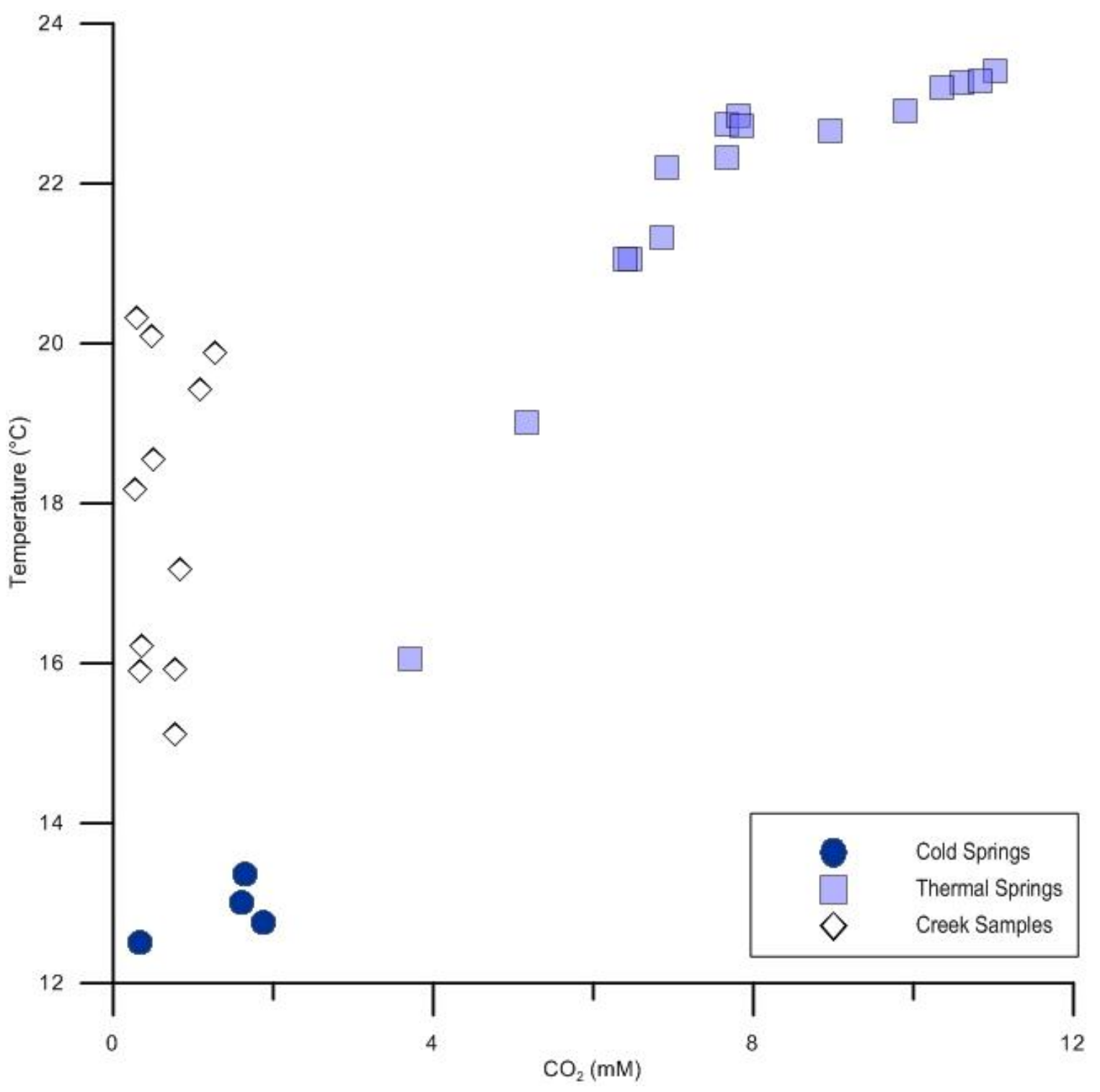

Figure $24-\mathrm{CO}_{2}$ vs temperature which separates the three distinct water types. Hollow samples represent stream samples and filled symbols represent springs. 


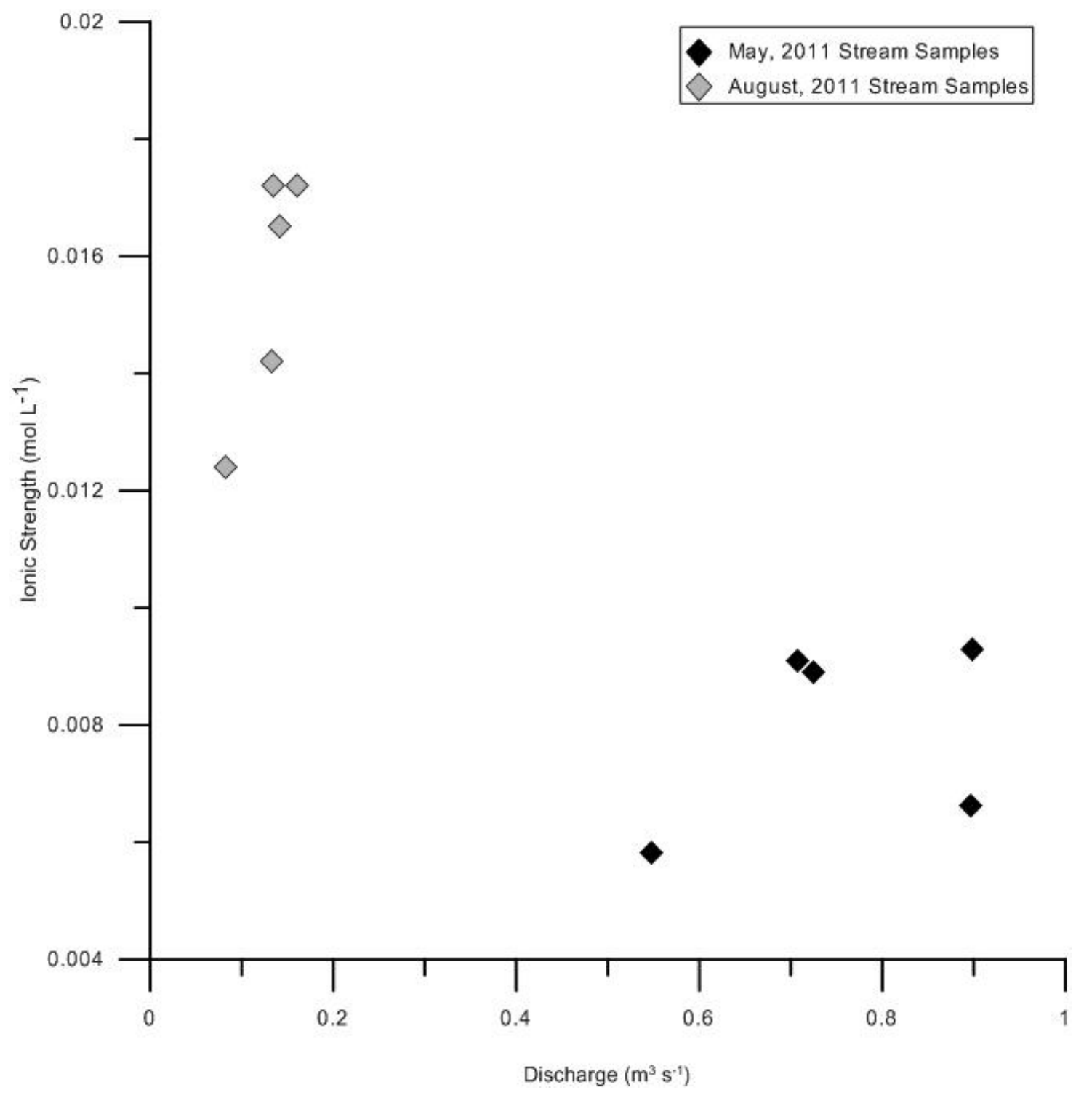

Figure 25 - Discharge versus ionic strength for stream samples in May, 2011 versus August, 2011. Lower discharge corresponds to significantly higher ionic strength in all samples. 
thermally mature and come into chemical equilibrium with respect to reservoir rocks (Hobba et al., 1979).

The cold springs are the likely the product of shallow flow in the carbonate units. This is supported by their cool nature and carbonate character, which is typical of other karst springs in the region being dominated by alkalinity, neutral $\mathrm{pH}$, and low $\mathrm{SO}_{4}{ }^{-2} / \mathrm{NO}_{3}$.

\subsubsection{Conceptual model for geology-water interaction}

The source of the thermal spring waters in the Sweet Springs Valley is difficult to determine because of the complex geochemistry, most notably the high TDS, temperature, $\mathrm{CO}_{2}$, and metal precipitates in spring pools. While definitively determining the source and processes that form the waters may not be possible, the use of an analogous system yields useful comparisons.

Thermal waters studied by Goldscheider et al. (2010) in Budapest, Hungary, have analogous characteristics to the thermal springs in Sweet Springs Valley and their origins may be similar. The thermal springs in Budapest have high TDS, thermal temperatures $\left(>100^{\circ} \mathrm{C}\right)$, high $\mathrm{CO}_{2}$, and precipitate iron oxides, manganese oxides, and travertine in their discharge zones. The springs emerge from faulted carbonates $(>2 \mathrm{~km})$ that are heavily fractured, resulting in localized pockets of thermal springs and cold springs adjacent to each other. Of particular interest, is the dominance of $\mathrm{SO}_{4}^{-2}$ in the Budapest springs which was hypothesized by Goldscheider et al. (2010) to be a result of dissolution of gypsum, andhydrite, and/or the oxidation of sulfide minerals both by oxygenated meteoric water and chemolithoautotrophic microorganisms. In such a scenario, the mineral dissolution reactions, both organic and inorganic, would produce acidity, in the form of $\mathrm{H}_{2} \mathrm{SO}_{4}$, which would induce secondary dissolution of carbonates (karstification) along the faults; the carbonate dissolution would mobilize $\mathrm{CO}_{2}$ and $\mathrm{Ca}^{2+}$.

The Sweet Springs Valley thermal springs have a similar geochemical profile to the Budapest springs, which is summarized below:

- $\mathrm{SO}_{4}^{-2}$ is the dominant anion (besides $\mathrm{HCO}_{3}{ }^{-}$) in both spring sets, which suggests dissolution of sulfur rich minerals and units.

- Temperature and $\mathrm{CO}_{2}$ are constant in thermal springs at both sites, suggesting deep circulation, fast upwelling, and limited atmospheric contact.

- Metal oxides precipitate at CHAL and CHAL2.0M springs as well as at the Budapest springs, suggesting reducing conditions at both sites until emergence. 
- Upwelling occurs near major regional faults and fracture zones adjacent to both warm and cold springs.

- In both Budapest and the Sweet Springs Valley, carbonates are dominant and interspersed with pyritic shales and gypsum interbeds; these units interact directly with the fault planes at both sites (Figure 26).

The absence of metal precipitates at OLDSWT spring may be explained by the lower $\mathrm{CO}_{2}$ concentrations compared to $\mathrm{CHAL}$, which indicates atmospheric exposure before the spring reaches the surface; the exposure would lead to oxidation of metals in solution. The temperature of the Budapest springs is much higher than that of the springs in Sweet Springs Valley as well, however, the geochemical similarities mentioned above support analogous processes for both systems.

\subsection{Rates of calcite precipitation}

The procedures of this study closely mirror those of Herman and Lorah (1988), Dreybrodt et al. (1992), and Zaihua et al. (1995) in that field-measured mass change of precipitation substrates are compared to the theoretical calcite precipitate rate equation, PWP, developed by Plummer et al. (1978). The results of the all three studies are similar to each other, where the PWP overestimates the calcite precipitation rates by one order-of-magnitude, with the exception of the Lorah and Herman $(1988 ; 1990)$, which reports up to two orders of magnitude overestimation.

Lorah and Herman (1990) performed their study approximately $35 \mathrm{~km}$ northeast of the current study area, in Falling Spring Creek, overlying the same lithology and a structural regime closely approximating the one present in the Sweet Springs Creek Valley. Their stream water chemistries were comparable in terms of total alkalinity, $\mathrm{pH}$, and major ions. However, the waters in Falling Spring Creek were warmer, ranging from $18.5^{\circ} \mathrm{C}$ to $25^{\circ} \mathrm{C}$. Falling Spring Creek also had higher $\mathrm{SO}_{4}^{-2}$, averaging $270 \mathrm{mg} \mathrm{L}^{-1}$ compared to an average of $67 \mathrm{mg} \mathrm{L}^{-1}$ and $164 \mathrm{mg} \mathrm{L}^{-1}$ for May, 2011 and August, 2011 respectively, for Sweet Springs Creek. Although the chemistries and settings of the sites are similar, the field-measured rates we determined are not as different from the PWP rate as those in Lorah and Herman (1990). Herman and Lorah calculated the surface area of the Iceland spar seed crystals used as substrate for precipitation; however the crystals were non-uniform in surface area, ranging from 20 to $30 \mathrm{~cm}^{2}$ (1990). The non- 


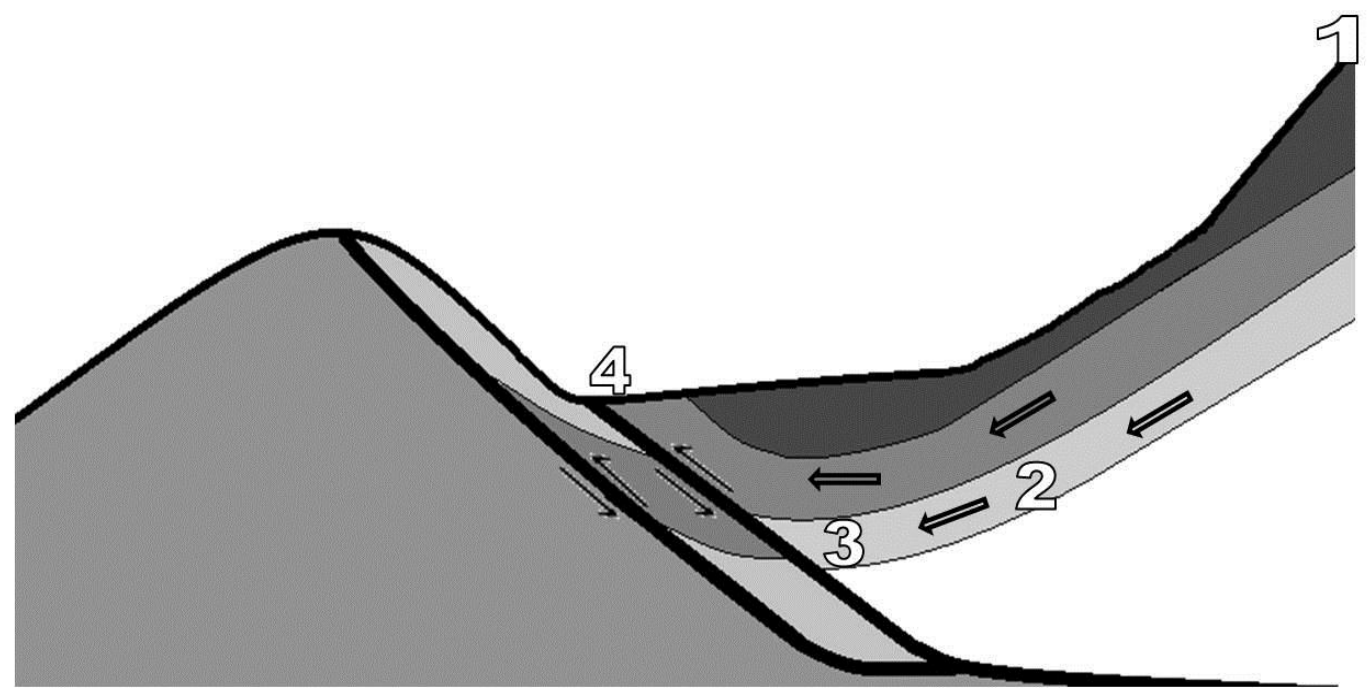

Figure 26 - Schematic of meteoric recharge of waters for an area like the Sweet Springs Valley. (1) recharge of oxygenated meteoric water, (2) flow of water down gradient and accumulation of carbonate character, (3) interaction with organic and pyritic shales along the fault plane and thermal maturation of waters, and (4) emergence of waters along fractures and conduits near the surface. 
uniformity of the crystals introduced variability between sample sites in the Falling Spring Creek study in the form of available surface area and flow interaction. The current study used a substrate with similar mineralogy to the travertine deposits in and near Sweet Springs Creek (microcrystalline $\mathrm{CaCO}_{3}$ ) and had known dimensions that were standardized between all sites.

Dreybrodt et al. (1992) and Zaihua et al. (1995) both used similar plate substrates (limestone and marble) to the current study and placed them in-situ in a similar fashion. Their studies yielded PWP rates approximately one order-of-magnitude larger than their fieldmeasured rates which is what was found in this study; the similar results illustrate the effectiveness of the PWP equation across varied geochemical settings (Table 15).

In all three of the previous studies, and in this study, $\mathrm{CO}_{2}$ outgassing was believed to be the primary control over calcite precipitation. However, Dreybrodt et al. (1992) and Zaihua et. al. (1995), also attempted to correct for the difference between the PWP rate and Fieldmeasured rates by quantifying the diffuse boundary layer on the precipitation substrate surface. The method relies on work by Dreybrodt and Buhmann (1991), where the diffusive boundary layer was determined by measuring the mass change in a pure gypsum plate of roughly the same dimensions as a travertine plate. Since gypsum dissolves entirely by diffusion, the diffuse boundary layer thickness could then be extrapolated. Dreybrodt et al. (1992) and Zaihua et al. (1995) used this correction factor to reduce their error by a factor of 10 , which effectively eliminated the difference between the PWP rate and the field-measured rates.

The study performed by Dreybrodt and Buhmann (1991) was conducted under laboratory conditions without the presence of organisms or foreign ions, such as $\mathrm{SO}_{4}^{-2}$. It is known that microorganisms can promote the formation of $\mathrm{SO}_{4}^{-2}$ minerals, especially in evaporitic environments, by way of incorporation of counter-cations such as $\mathrm{Ca}^{2+}$ and $\mathrm{Sr}^{2+}$ when high concentrations of $\mathrm{SO}_{4}^{-2}$ are available (Konhauser, 2007). Additionally, the effective activity of $\mathrm{Ca}^{2+}$ is reduced in the presence of $\mathrm{SO}_{4}{ }^{-2}$ by conversion of $\mathrm{Ca}^{2+}$ to the ion-pair $\mathrm{CaSO}_{4}{ }^{\circ}$ (Dreybrodt et al., 1992). The effectiveness of these factors may be negligible when compared to the overall diffusion rate of gypsum; however, the presence of $\mathrm{SO}_{4}^{-2}$ minerals in samples from Sweet Springs Creek suggests that more detailed analyses of gypsum diffusion in high $\mathrm{SO}_{4}{ }^{-2}$ waters is needed. 
Table 15 - Comparsion of rates from other studies

\begin{tabular}{lcccc}
\hline \hline & $\begin{array}{c}\text { Lowest Field } \\
\text { Precipitation } \\
\text { Rate }\end{array}$ & $\begin{array}{c}\text { Highest Field } \\
\text { Precipitation } \\
\text { Rate }\end{array}$ & $\begin{array}{c}\text { Lowest PWP } \\
\text { Precipitation } \\
\text { Rate }\end{array}$ & $\begin{array}{c}\text { Highest PWP } \\
\text { Precipitation } \\
\text { Rate }\end{array}$ \\
\hline \hline $\begin{array}{l}\text { Lorah and } \\
\text { Herman (1990) }\end{array}$ & $3.42 \times 10^{-8}$ & $-1.27 \times 10^{-6}$ & $4.4 \times 10^{-10}$ & $-1.2 \times 10^{-7}$ \\
$\begin{array}{l}\text { Dreybrodt et. al } \\
\text { (1992) }\end{array}$ & Not Given & Not Given & $6.50 \times 10^{-11}$ & $-2.8 \times 10^{-11}$ \\
$\begin{array}{l}\text { Zaihua et al. } \\
\text { (1995) }\end{array}$ & $\leq-1.00 \times 10^{-13}$ & $-1.00 \times 10^{-10}$ & $-1.79 \times 10^{-10}$ & $-6.56 \times 10^{-10}$ \\
\hline \hline
\end{tabular}

Note: all rates given in $\mathrm{mol} \mathrm{cm} \mathrm{cs}^{-1}$ as $\mathrm{CaCO}_{3}$ 


\subsection{Impacts of non-carbonate components}

\subsubsection{Previous research}

A compounding factor in determining field rates of calcite precipitation is the increase in plate mass by addition of minerals/compounds other than calcite; these could either be mineralogical or biological. While additional mass has been discussed in the literature, it is usually with respect to morphological characteristics of travertine rather than proportion of the travertine mass.

Chafetz et al. (1991) identified different carbonate mineralogy in conjunction with the presence of microorganisms but did not quantify the proportions or degree to which the mineralogy was affected. Lu et al. (2000) identified the presence of microorganisms and dissolution etching in calcite precipitates while Gradzinski (2010) described the incorporation of macro and microorganisms into travertine and the morphology of travertines. Lu et al. (2000) alluded to the presence of minerals (metal oxides) other than calcite in precipitates and found vaterite, a polymorph of calcite, via X-ray diffraction in their study. However, they did not analyze the precipitate for oxide content or quantify the proportions of the mineral precipitate that were not calcite.

The lack of precipitate chemical analysis and consideration of biologic mass is a significant shortcoming in the precipitation rate investigations; as shown in the current study, precipitates other than $\mathrm{CaCO}_{3}$ can significantly contribute to the total precipitate mass and inflate estimates of calcite precipitation (Table 14). Metal oxides, as suggested by Lu et al. (2000), were found in concentrations nearing $9 \%$ of the total mass on plates. Detrital components were also overlooked although they are important components in the structures benthic organisms build in the calcite precipitate, such as midge larval casings (Steven Harris, Personal Communication, September, 2011), and are incorporated into the $\mathrm{CaCO}_{3}$ matrix. The importance of biologic components, especially on CREEK4010 and CREEK4120, illustrates the ability of biota to significantly influence mass interpretations as the plates had little calcite growth but significant mass gain throughout the study. While biologic components are considered a natural part of travertine, the need to differentiate their mass from inorganic mass is especially important in those waters in which biologic colonization is pervasive.

Precipitation plates had greater than $10 \%$ of their precipitate mass as non-calcite, which illustrates the bias that can be introduced to mass estimates. Assessments of organic content by way of sample combustion is also available, as was done with XRF-F which liberated $40 \%$ or 
more of the mass in all samples from Sweet Springs Creek; it is important to note that any hydrated mass was liberated as well. Error in mass accreted due to organics and hydrated minerals (not discussed here) would be higher if they were considered in greater detail.

\subsubsection{XRF-Fusion and SEM-EDS}

SEM-EDS analysis compared to XRF-F analysis suggests that the approximate precipitate chemistry can be evaluated in a semi-quantitative fashion using SEM-EDS in a method that is representative of the entire plate (Table 16). However, XRF-F is a more accurate assessment of true mineral content of the precipitates due to it being quantitative and representative of the entire sample.

SEM-EDS consistently showed higher concentrations of all minerals, with the exception of $\mathrm{CaO}$, than the XRF-F analysis. The higher concentrations are likely an artifact of the SEM-EDS only capturing the relative surface elemental chemistry rather than the true mineral composition as is the case with XRF-F. It is also possible that the SEM-EDS analysis was erroneous due to background interference from the travertine substrate. Although SEM-EDS only penetrates to a depth of approximately $15 \mu \mathrm{m}$, there were portions of plates from CREEK3890, CREEK4010, and CREEK4120 that were not encased in precipitate which would give readings of the background substrate. An analysis of the precipitate substrate before the study would have provided a means by which the substrate geochemistry could be differentiated from that of the precipitate during SEM-EDS analysis.

\subsection{Inhibition of precipitate formation}

Inhibition and reduction of $\mathrm{CaCO}_{3}$ precipitation has been evaluated in laboratory settings, but little work has gone into identifying the degree of inhibition or the cumulative effects of the inhibitors described in those studies in natural settings relative to precipitation rate analyses (Buhmann and Dreybrodt, 1987; Chou et al., 1989; Inskeep and Bloom, 1986; Lebron and Suarez, 1996; Meyer, 1984; Reddy, 1977; Reddy, 1986; Stoessell, 1992). Dreybrodt et al. (1992) and Zaihua et al. (1995) incorporated the effects of the diffuse boundary layer, but no known precipitation studies have considered other suspected and known inhibitors in a quantitative fashion, such as competitive ions $\left(\mathrm{Mg}^{2+} \mathrm{SO}_{4}{ }^{2-}, \mathrm{Fe}^{2+, 3+}\right.$, phosphates), $\mathrm{DOC}$, and microorganisms.

Microorganisms and algae are incorporated into many travertine deposits; however their role in precipitation dynamics is not entirely clear. Chafetz et al. (1991) and Gradzinski 
Table 16 - Comparison of SEM-EDS and XRF-fusion for precipitates

\begin{tabular}{llccccccc}
\hline \hline Analysis & Site & $\mathrm{MgO}$ & $\mathrm{Al}_{2} \mathrm{O}_{3}$ & $\mathrm{SiO}_{2}$ & $\mathrm{~K}_{2} \mathrm{O}$ & $\mathrm{MnO}$ & $\mathrm{FeO}$ & Comments \\
\hline \hline SEM-EDS & CREEK3740 & 0.70 & 3.20 & 15.40 & 0.60 & 0.60 & 1.60 & \\
XRF Fusion & CREEK3740 & 0.45 & 1.39 & 7.13 & 0.07 & 0.15 & 0.48 & $\mathrm{As} \mathrm{Fe}_{2} \mathrm{O}_{3}$ \\
\hline SEM-EDS & CREEK6115 & 0.50 & 0.80 & 3.80 & 0.20 & 0.30 & 0.40 & \\
XRF Fusion & CREEK6115 & 0.47 & 0.61 & 3.49 & 0.01 & 0.05 & 0.30 & $\mathrm{As} \mathrm{Fe}_{2} \mathrm{O}_{3}$ \\
\hline \hline
\end{tabular}

Notes: XRF-fusion values represent \% mass of analyte relative to total mass before combustion; SEM-EDS values represent $\%$ of analyte on plate surface via composite EDS captures 
(2010) reported that the participation of microorganisms and algae enhances the precipitation of $\mathrm{CaCO}_{3}$ in travertine-depositing streams due to increases in surface area, while Lu et al. (2000) found that some organisms, diatoms and algae, were associated with decreases in fieldmeasured calcite precipitation rates and their presence coincided with dissolution features on calcite crystals. As observed by Lu et al. (2000), precipitation rates were lower at sites exhibiting algae and diatom colonization in Sweet Springs Creek samples. No precipitates were observed in conjunction with these organisms either, suggesting they did not increase calcite precipitation rates on plates in Sweet Springs Creek. However, the relationship between organism presence and lower calcite precipitation rates may be more a function of water turbulence than of colonization; some algae have been shown to have difficulty colonizing the turbulent zones where most precipitation initiated (Hondzo and Lyn, 1999).

Dissolved organic carbon (DOC) can limit and even eliminate $\mathrm{CaCO}_{3}$ precipitation, but no analyses of DOC relative to field-measured precipitation rates are known (Inskeep and Bloom, 1986; Lebron and Suarez, 1996). DOC concentrations in Sweet Springs Creek surpassed those known to inhibit $\mathrm{CaCO}_{3}$ precipitation from Lebron and Suarez (1996) and given the nearly identical settings of Lorah and Herman (1990), were likely above the threshold there as well; Lorah and Herman noted that DOC could possibly inhibit calcite precipitation but did not evaluate concentrations of DOC. Comparison of field-measured precipitation rates for the August 2012 plate set, where DOC concentrations surpassed the $0.15 \mathrm{~mm}$ threshold described by Lebron and Suarez (1996), shows precipitation rates decreased in accordance with increased DOC (Figure 27). Based on other studies and the data from Sweet Springs Creek, it is likely that DOC inhibits calcite precipitation and that some degree of inhibition is occurring at most travertine sites due to the prevalence of biota in and on the travertine matrix.

lons other than $\mathrm{Ca}^{2+}$ are known inhibitors of calcite precipitation and nucleation as described extensively by both Reddy $(1977 ; 1986)$ and Meyers (1984); however, little consideration has been given to those ions in the natural settings where calcite precipitation rates were evaluated. The presence of these ions, most specifically $\mathrm{SO}_{4}{ }^{2-}$ and $\mathrm{Mg}^{2+}$, leads to the increased solubility of $\mathrm{CaCO}_{3}$ (Akin, 1964) and competition for lattice growth sites by these ions. In Lorah and Herman (1990), the waters had concentrations of $\mathrm{SO}_{4}{ }^{2-}$ greater than any other dissolved ion, which they mentioned and identified as a possible inhibitor, but they did evaluate co-precipitates or lattice site competition. Takano et al. (1980) found $\mathrm{SO}_{4}{ }^{-2}$ in homogenized 


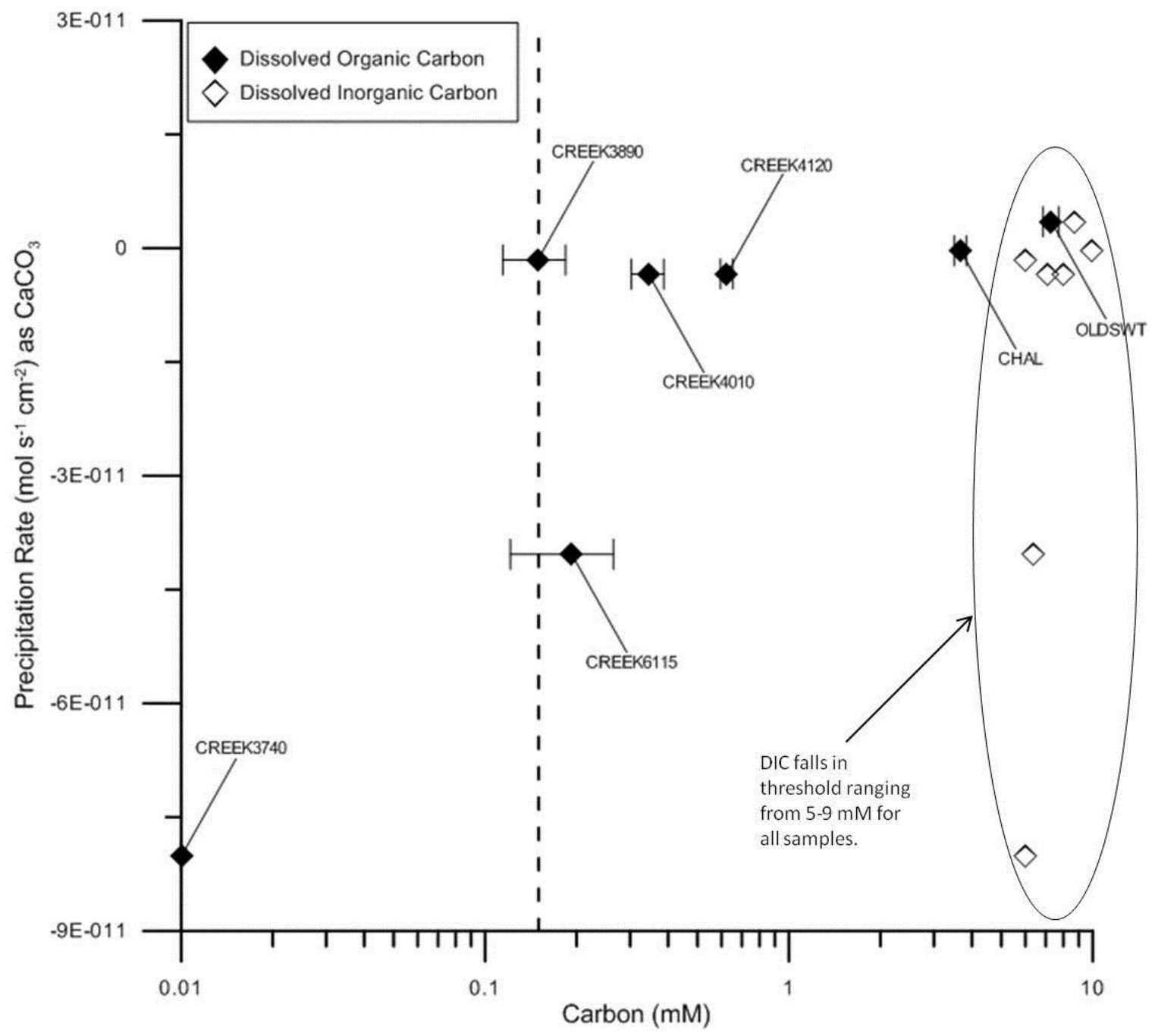

Figure 27 - DOC and DIC plotted against field calculated precipitation rate for samples from August, 2011 and OLDSWT May, 2011. Samples above the $0.15 \mathrm{mM}$ threshold tended to have a slower precipitation rate than those below it. All samples have similar DIC concentrations with the thermal springs gapping the upper threshold. CREEK3740 is below the detection limit but is plotted to illustrate rate. Dashed line represents DOC threshold $(0.15 \mathrm{mM})$ from Lebron and Suarez (1995). 
mineral samples from travertines from their study and gypsum precipitate was present on plates in Sweet Springs Creek; both findings illustrate the incorporation of active precipitation inhibitors in the travertine matrix.

Researchers are beginning to consider the role of biofilms in travertine precipitation (Allen et al., 1997; Boomer et al., 2009; Okumura et al., 2012). Okumura et al. in particular, found that diurnal cycles controlled lamination of travertine due to the activity of cyanobacterial mats, which grew during the day and increased the thickness/porosity of day-time layers (2012). This finding suggested that travertine growth is to a degree dependent on amount of sunlight exposure when complimented by bacterial mats. Although sunlight was absent for most of the day at all sites in the current study, "mucus films" as described by Allen et al. (1997) were present in most of Sweet Springs Creek. It is likely that all travertines are subject to biofilms; as such biofilms need to be considered not only when designing a precipitation rate study, accounting for where sunlight prohibits or encourages biofilm growth, but also evaluated with respect to the degree of influence that biofilms have on precipitation rates directly.

Calcite precipitation inhibition analysis was inconclusive with respect to any one parameter. However, correlations were found between a decrease in calcite precipitation rate with increasing abundance of DOC as well as the increased presence of algae and diatoms. It is appears that co-precipitation of minerals other than calcite limited potential surface area for calcite precipitation, which would effectively lower the amount of calcite accreted throughout the study. No statistically significant correlation was found between specific ions and a decrease in precipitation rate; the lack of correlation is likely due to the presence of multiple known inhibitors and non-ionic inhibitors, such as biota and DOC. However, the co-precipitation of a sulfate mineral (selenite) suggests competition for $\mathrm{Ca}^{2+}$ ions in aqueous solution, to form the ion pair $\mathrm{CaSO}_{4}{ }^{0}$, and thus less potential for calcite precipitation when $\mathrm{Ca}^{2+}$ complexed with $\mathrm{SO}_{4}^{-2}$ (Dreybrodt et al., 1992).

\subsection{Implications for carbon sequestration}

In CCS applications the flue gases pumped into reservoirs are not pure $\mathrm{CO}_{2}$ and include sulfur dioxide and un-combusted solid materials (fine particulate). As such, it is likely that any fluids that leak from the CCS reservoirs would contain significant concentrations of $\mathrm{SO}_{4}{ }^{2-}$ from both flue gas and possible enhancement due to the dissolution of both pyrites and evaporates. While the degrees of inhibition caused by $\mathrm{SO}_{4}{ }^{2-}$ in the precipitation of travertine are inconclusive in the geochemical setting described, it is possible to extrapolate that the enhanced 
concentrations would cause decreased precipitation rates. The un-combusted solid materials, effectively coal particulates, would introduce long carbon chain organics which are known inhibitors (Lebron and Suarez, 1996). The effects of these inhibitors would in all likelihood be minimal considering they are very small factions of the total flue gas composition $(<1 \%)$ (Ali, 2007).

Ecosystems developed in and near travertine precipitating thermal springs are similar in that they all have micro and macro-organisms growing in the travertine matrix (Chafetz and Folk, 1983; Pentecost, 2005). The organisms comprising these ecosystem can vary significantly from typical assemblages that occur in the given geographic region due to the nutrient load and thermal nature of the waters (Boomer et al., 2009; Pentecost, 2005). The contrasting ecosystems that develop near travertine would likely be analogous to ecosystems that might develop near $\mathrm{CO}_{2}$ leaks from CCS reservoirs. Those ecosystems may provide a proxy by which "leaky" CCS reservoirs could be detected as the ecological footprint would likely be significantly different than the base-line for the region.

\subsection{Inherent limitations in calcite precipitation rate studies}

Rain precipitation and the resulting increased discharge would have diluted ionic strength in Sweet Springs Creek in pulses, which would lead to unaccounted for variability in the stream geochemistry; the pulses of rain precipitation were inferred from Onset ${ }^{\circledR}$ Hobo temperature data (Figure 28). Dreybrodt et al. (1992) indicated that although chemical variability existed at their sites as well, associated with rain precipitation, no variation in calcite precipitation rate was observed. However, the differences between PWP rates between May, 2011 and August, 2011 are likely due to dilution in the Sweet Springs Creek samples as increased discharge correlates with decreased ionic strength and subsequently decreased precipitation rates (Figure 29). Field-measured rates do not appear to be as dependent on stream chemistry and had less variability than the PWP rates in Sweet Springs Creek. The differences in PWP rates may be expressed relative to the degree of variability in stream chemistry and as such may not have been reflected to the same extent in Dreybrodt et al. (1992).

Water sampling was done in discrete intervals, over a 1 to 3 day period on all trips. The chemistry data gathered during these short periods of time were used as a representative sample of the time that mineral precipitation plates were in-situ. This "chemical snapshot" doesn't encompass discharge changes and dilution due to rain precipitation during the full incubation period and represents a non-uniform chemistry that cannot be fully accounted for. 


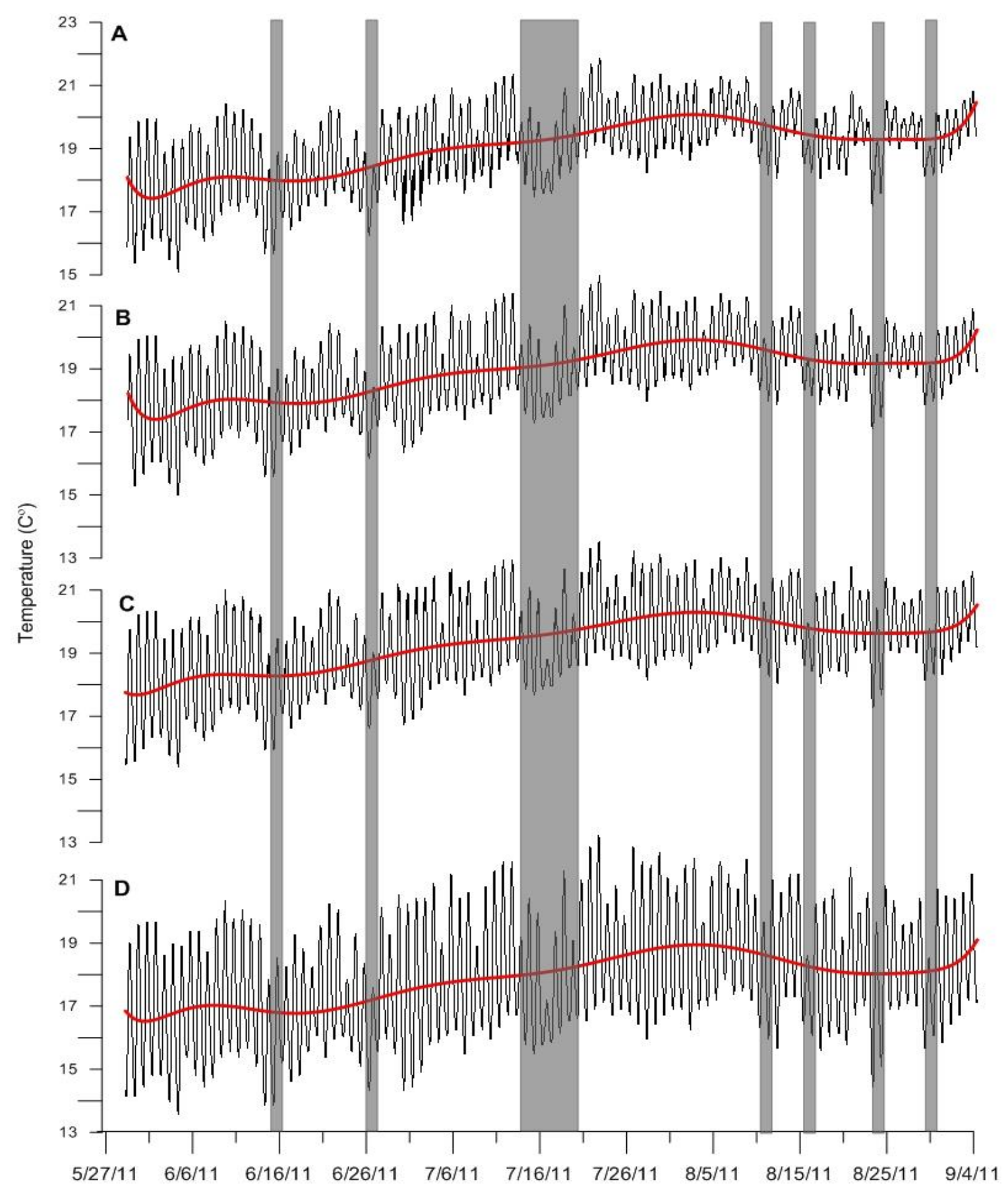

Figure 28 - Temperature data for stream samples (A) CREEK4120, (B) CREEK4010, (C) CREEK3890, and (D) CREEK3470. The lighter horizontal line represents the floating average temperature at each site. The shaded areas represent perceived rain precipitation events accentuated by sharp decreases in stream temperature. 


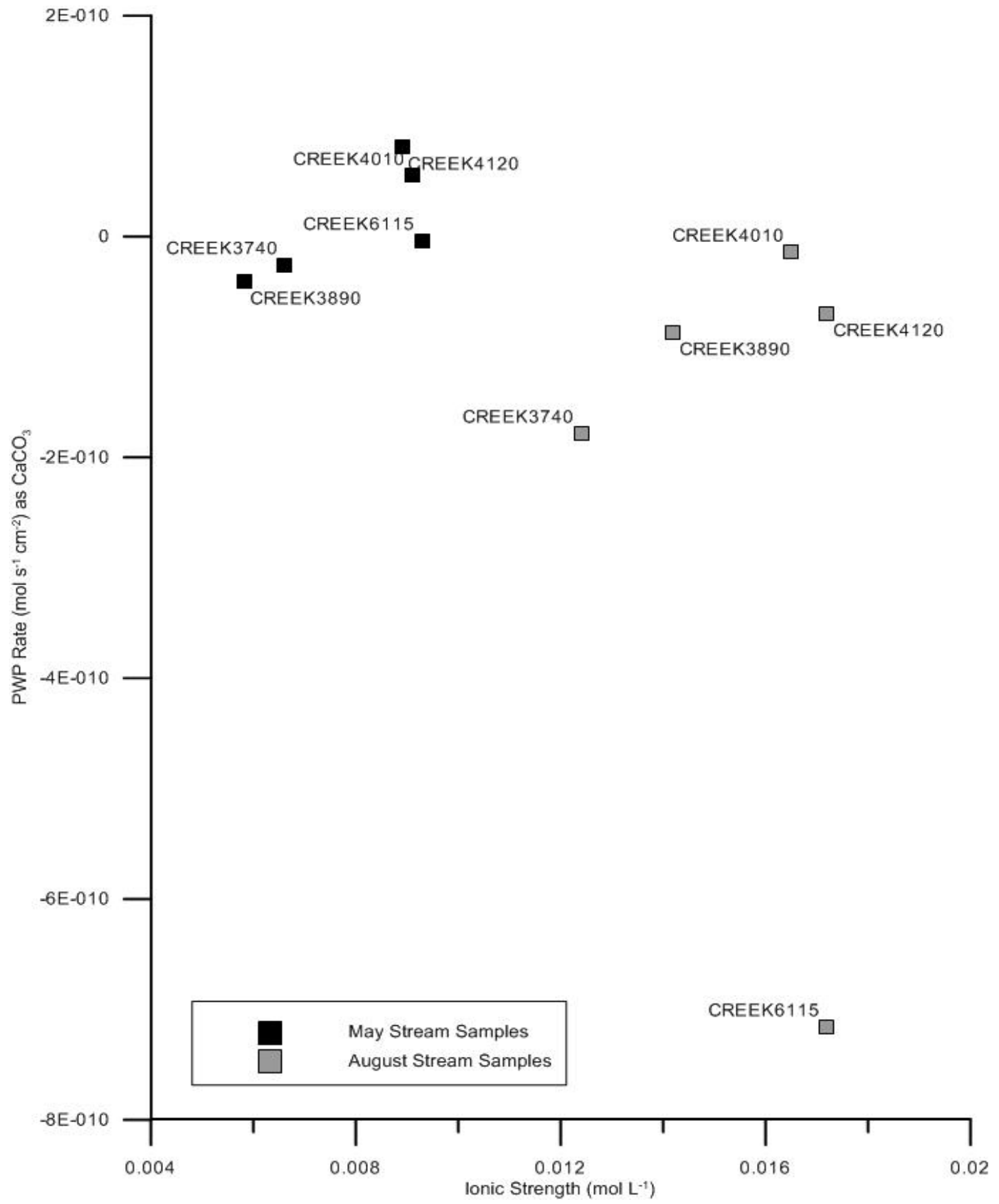

Figure 29 - Ionic strength compared to (PWP) precipitation rates. August samples have a higher ionic strength due to less discharge which increases the calculated PWP rate whereas May samples have a lower ionic strength and lower PWP rates. 
Additionally, travertine systems are known to be responsive to diel cycling where both hydrogeochemistry and growth rates are directly proportional to the degree of sunlight exposure/time of day (Boomer et al., 2009; Drysdale et al., 2003).

Alkalinity titrations were performed with the assumption that, most if not all, of the titratable ions were carbonate. However, organic bases, such as amines, in the system would also consume acidity during titration and result in over estimation of the alkalinity, and subsequent estimation of $\mathrm{CO}_{2}$. The variability seen between measured and calculated values of $\mathrm{CO}_{2}$ may be a result of the alkalinity values input into Visual Minteq ${ }^{\circledR}$ being inflated with noncarbonate bases (Figure 30). The larger the magnitude of $\mathrm{CO}_{2}$, the more deviation from linearity that was seen when the CarboQC ${ }^{\circledR}$ was compared to Visual Minteq ${ }^{\circledR}$ predictions.

Geochemical models have been used to estimate saturation indices, model precipitation dynamics, and predict precipitate mineralogy. However, unlike in other studies, the $\mathrm{SI}_{\text {CALCITE }}$ in Sweet Springs Creek never surpassed the critical threshold of 5-10 for calcite precipitation, but precipitation of $\mathrm{CaCO}_{3}$ was still observed (Chafetz et al., 1991; Dreybrodt et al., 1992; Herman and Lorah, 1988; Lu et al., 2000; Zaihua et al., 1995) (Table 10). Additionally, geochemical modeling did not predict a $\mathrm{SI}_{\text {GYPSUM }}>0$; however, authigenic gypsum (selenite) crystals were observed on plates from CREEK3890. Metal oxides, shown in Table 14, were also undersaturated in the solution and not observed, however it is unknown if they are authigenic or colloids/detrital. It is possible that undersaturated minerals precipitate due to microbial metabolism, in effect changing the localized kinetics of the precipitate substrate such that undersaturated minerals are kinetically favorable (Konhauser, 2007). The presence of undersaturated minerals suggests that dependence on geochemical models to predict mineral stability in travertine depositing systems may not always be sufficient, and that evaluation of biologic interactions may also be needed.

\subsection{Future work}

The research presented here is an attempt at semi-quantitatively evaluating precipitation dynamics of travertine but leaves many avenues for improvement in future research. Perhaps the most valuable asset to a study of this kind is tandem laboratory analysis of the proposed reactions taking place in-situ. The hypotheses presented here were not always conclusive, primarily with respect to inhibitors. Field water samples could be used in conjunction with various ionic additives and concentrations to evaluate changes in precipitation rate/mass. Laboratory analysis could be used to control $\mathrm{CO}_{2}$ exsolution and more closely 
evaluate $\mathrm{SI}_{\text {calcite }}$ in representative water samples. Additionally, laboratory experiments could evaluate rates with and without the presence of organisms. It is possible as well that the above variables could be co-dependent and such relationships could be identified via laboratory experiments.

The substrate for the precipitation experiments, Turkish travertine, was chosen because it was a representative matrix. However, the tiles themselves were a possible interference during SEM-EDS analysis. The tiles also had varying porosity, although limited, which inevitably contributed to erroneous plate surface area measurements. In future research, it would be pertinent to use multiple matrix types when evaluating precipitation.

The placement of precipitation substrates, both in the stream channel and orientation relative to flow, should be considered in a more quantitative and deliberate manner. Although the plates in this study were placed in a similar position in the channel with the same orientation to flow, the channel and flow regimes were highly variable which would create different surface flow dynamics on the substrate. In utilizing gypsum plates, Dreybrodt and Buhmann (1991) attempted to account for the flow dynamics by estimating the diffuse boundary layer; however, their evaluation also overlooks the variability of stream channels and the irregularity of flow dynamics along any given stream reach. Future research may be able to better constrain variability between measurement sites by considering both the diffuse boundary layer and stream channel dynamics when placing precipitation substrates in-situ.

Microorganisms are an integral part of travertine, however, better classification and evaluation of their importance is needed in order to facilitate meaningful conclusions. Although organisms were evaluated sparingly in the current study, there was not a clear differentiation between macro versus microorganisms. Classifying organisms based on size is needed because bacteria are the basis for biofilms which are likely affecting travertine precipitation dynamics differently than macro organisms such as midges. 


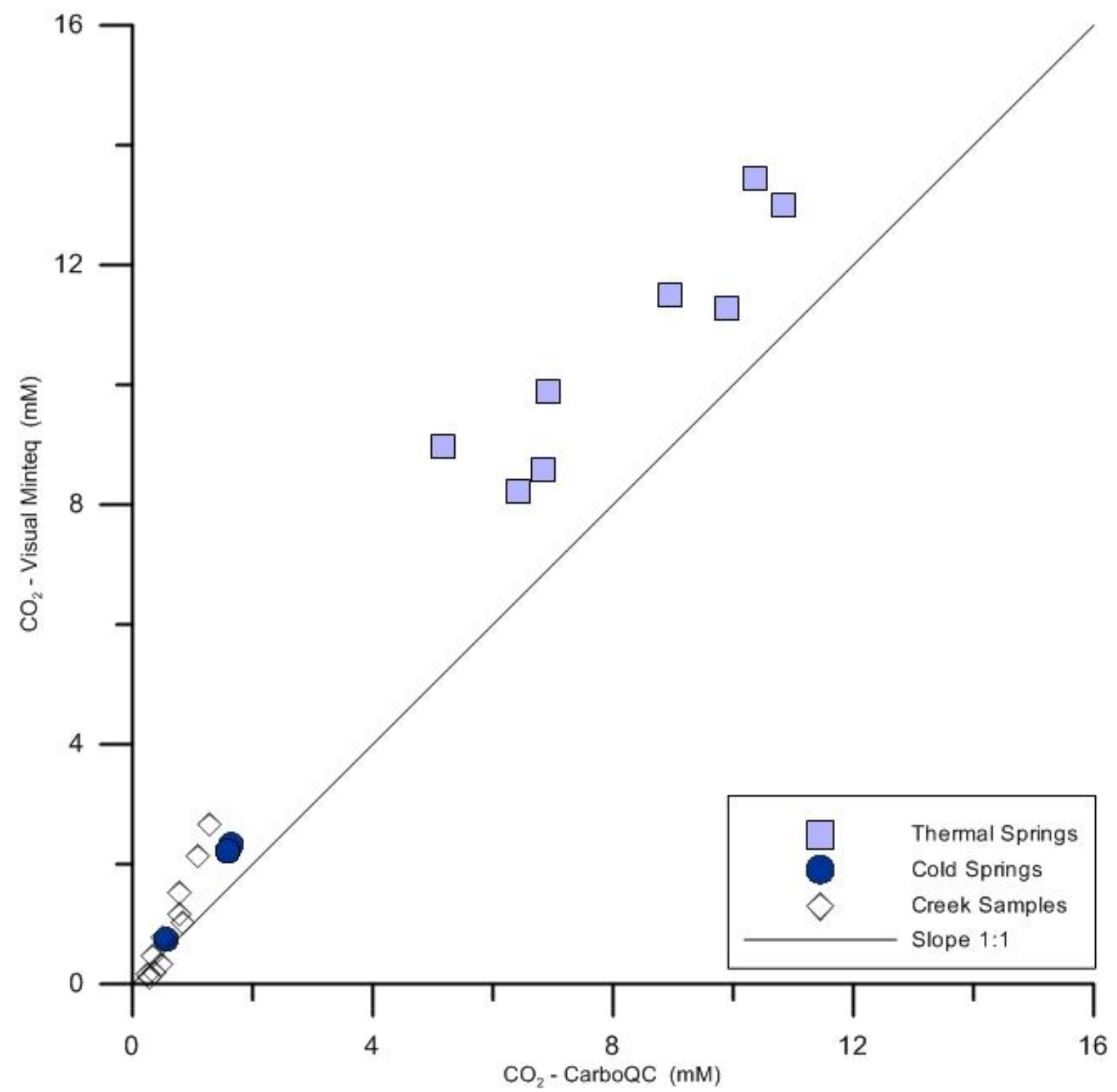

Figure $30-$ CarboQC vs. Visual Minteq carbon dioxide measurements compared. Visual Minteq consistently predicted higher $\mathrm{CO}_{2}$ values than were measured via the CarboQC suggesting erroneous alkalinity measurements. 


\subsection{Conclusions}

The conceptual model for the water-rock interactions illustrates the complexity in delineating the origin and characterizing flow paths of the Sweet Springs Valley thermal springs. However, the proposed model gives an approximation of the processes occurring at depth and allows for a better understanding of the geochemistry in association with the geology. The analog region in Budapest is a well suited match based on lithology, geochemistry, and structural character.

Field-measured rates on travertine tiles in Sweet Springs Creek were on average one order-of-magnitude lower than the rates predicted by the PWP rate equation. The consistent results obtained from the PWP equation when compared to field precipitation rates illustrated the viability and accuracy of the PWP rate equation for use in conjunction with field-measured rates in determining calcite precipitation rates. However, the data from Sweet Springs Creek suggest that most, if not all, calcite (travertine) precipitation rate studies can be refined and more accurately quantified by analyzing the mineral precipitates for solid geochemistry as well as precipitate characteristics. Not all precipitate is calcite in travertine-depositing systems and it is more akin to a mixture of different oxides, biota incorporated into travertine, and detrital minerals in addition to calcite.

The relative effects that $\mathrm{DOC}$, competitive ions, biota, and coprecipitation had on measured calcite precipitation rate were difficult to quantify due to both the number of variables and the relative magnitude of each in increasing or decreasing precipitate mass gained. Given our findings in Sweet Springs Creek, it is likely that all the variables mentioned affected the final observed field rates, however, some factors, such as DOC and competitive ions, appear to reduce precipitation rate while biota and detrital minerals appear to inflate estimates.

While this study examined potential inhibitors of calcite precipitate and limitations associated with measuring precipitation rate, it did not quantitatively do so. As such, future work should focus on quantifying individual variables relative to the total rate in order to accurately depict the level of influence each has on final measured precipitation rates. Furthermore, studies should consider the role of competitive ions, biota, and DOC in the reduction or enhancement of both precipitate rate and nucleation of calcite in natural settings, as these variables were all active in Sweet Springs Creek and corresponded to differential rates of calcite precipitation. 


\section{References:}

Akin, G.W., 1964. Calcium carbonate equilibrium in solutions open to the air- II. Enhanced solubility of $\mathrm{CaCO}_{3}$ in the presence of $\mathrm{Mg}^{2+}$ and $\mathrm{SO}_{4}{ }^{2-}$. Geochimica et Cosmochimica Acta, 29(4): 353-360.

Ali, S.M., 2007. $\mathrm{CO}_{2}$-flue gas separation for a conventional coal-fired power plant (first approach). M.S. Thesis, University of Boras, Boras, Sweden, 57 pp.

Allen, C.C., Thomas-Keprta, K.L., McKay, D.S., Chafetz, H.S., March 17-21, 1997, Nanobacteria in carbonates. Lunar and Planetary Science Conference, Houston, TX.

Allison, J.D., Brown, D.S., Novo-Gradac, K., 1991. MINTEQA2 / PRODEFA2, a geochemical assessment model for environmental systems. United States Environmental Protection Agency, pp. 144.

Annunziatellis, A., Beaubien, S.E., Bigi, S., Ciotoli, G., Coltella, M., Lombardi, S., 2008. Gas migration along fault systems and through the vadose zone in the Latera caldera (central Italy): Implications for $\mathrm{CO}_{2}$ geological storage. International Journal of Greenhouse Gas Control, 2(3): 353-372.

Aquilano, D., Costa, E., Genovese, A., Massaro, F.R., Pastero, L., Rubbo, M., 2003. Hollow rhombohedral calcite crystals encompassing $\mathrm{CO}_{2}$ microcavities nucleated in solution. Journal of Crystal Growth, 247(3-4): 516-522.

Bailey, C.M., 2000. Major faults \& high-strain zones in Virginia. Bailey, C.M. (Ed.). College of William and Mary, Williamsburg, VA. [http://web.wm.edu/geology/virginia/provinces/pdf/va faults.pdf] July 30, 2012.

Bedinger, M.S., Pearson, F.J., Reed, J.E., Sniegocki, R.T., Stone, C.G., 1979. The waters of Hot Springs National Park, Arkansas: their nature and origin. United States Geological Survey, Reston, VA. Geological Survey Professional Paper, 1044-C.

Benson, S.M., 2006. Carbon dioxide capture and storage: Assessment of risks from storage of carbon dioxide in deep underground geological formations, Lawrence Berkeley National Laboratory,, Berkeley, California, pp. 26.

Boomer, S.M., Noll, K.L., Geesey, G.G., Dutton, B.E., 2009. Formation of multilayered photosynthetic biofilms in an alkaline thermal spring in Yellowstone National Park, Wyoming. Applied and Environmental Microbiology, 75(8): 2464-2475.

Buchanan, T.J., Somers, W.P., 1969. Discharge measurements at gaging stations: United States Geological Survey techniques of water-resources investigations, Applications of Hydraulics. Techniques of Water-Resource Investigations of the United States Geological Survey, 3. United States Government Printing Office, Washington D.C., pp. 64.

Buhmann, D., Dreybrodt, W., 1987. Calcite dissolution kinetics in the system $\mathrm{H}_{2} \mathrm{O}-\mathrm{CO}_{2}-\mathrm{CaCO}_{3}$ with participation of foreign ions. Chemical Geology, 64(1-2): 89-102.

Busenberg, E., Plummer, L.N., 1985. Kinetic and thermodynamic factors controlling the distribution of $\mathrm{SO}_{4}{ }^{2-}$ and $\mathrm{Na}^{+}$in calcites and selected aragonites. Geochimica et Cosmochimica Acta, 49(3): 713-725.

Chafetz, H.S., Folk, R.L., 1983. Travertines: Depositional morphology and the bacerially constructed constituents. Journal of Sedimentary Petrology, 54(1): 289-316.

Chafetz, H.S., Rush, P.F., Utech, N.M., 1991. Microenvironmental controls on mineralogy and habit of $\mathrm{CaCO}_{3}$ precipitates: an example from an active travertine system.

Sedimentology, 38: 107-126.

Chou, L., Garrels, R.M., Wollast, R., 1989. Comparative study of the kinetics and mechanisms of dissolution of carbonate minerals. Chemical Geology, 78(3-4): 269-282. 
Clauson-Wicker, S., 2008. Sweet dreams longtime mineral spa resort is being rejuvenated, Free Lance-Star Publishing. The Free Lance-Star Publishing Co. , Fredericksburg, VA.

Cline, J.D., 1969. Spectrophotometric Determination of Hydrogen Sulfide in Natural Waters. Limnology and Oceanography, 14(3): 454-458.

Collins, W.D., Foster, M.D., Reeves, F., Meacham, R.P., 1930. Springs of Virginia: A report on the discharge, temperature, and chemical character of springs in the southern part of the Great Valley. Virginia Division of Water Resources and Power, Richmond, VA. Bulletin No. 1.

Cumming, K.A., 1997. Hydrogeochemistry of groundwater in Chimayo, New Mexico. M.S. Thesis, Northern Arizona University, Flagstaff, AZ, $117 \mathrm{pp}$.

Dennison, J.M., Johnson, R.W., 1971. Tertiary intrusions and associated phenomena near the thirty-eighth parallel fracture zone in Virginia and West Virginia. Geological Society of America Bulletin, 82: 501-508.

Drever, J.I., 1997. The geochemistry of natural waters. Prentice Hall, Englewood Cliffs, N.J., pp. 41-53.

Dreybrodt, W., Buhmann, D., 1991. A mass transfer model for dissolution and precipitation of calcite from solutions in turbulent motion. Chemical Geology, 90: 107-122.

Dreybrodt, W., Buhmann, D., Michaelis, J., Usdowski, E., 1992. Chemically controlled calcite precipitation by $\mathrm{CO}_{2}$ outgassing: Field measurements of precipitation rates in comparison to theoretical predictions. Chemical Geology, 97: 285-294.

Drysdale, R., Lucas, S., Carthew, K., 2003. The influence of diurnal temperatures on the hydrochemistry of a tufa-depositing stream. Hydrological Processes, 17: 3421-3441.

Engel, A.S., Porter, M.L., Kinkle, B.K., Kane, T.C., 2001. Ecological assessment and geological significance of microbial communities from Cesspool Cave, Virginia. Geomicrobiology Journal, 18(3): 259-274.

Farrar, C.D., Neil, J.M., Howle, J.F., 1999. Magmatic carbon dioxide emissions at Mammoth Mountain, California. United States Geological Survey, Sacramento, CA. WaterResources Investigations Report, 98-4217.

Global Carbon Capture and Storage Institute, 2012. Global status of CCS: Update to 3rd Clean Energy Ministerial, Clean Energy Ministerial, Paris, France, pp. 7.

Goggin, K.E., 1991. Mud pot: A new thermal water cave in Alleghany County, Virginia, Appalachian Karst - Proceedings of the Appalachian Karst Symposium, pp. 51-57.

Goldscheider, N., Madl-Szonyi, J., Eross, A., Schill, E., 2010. Review: Thermal water resources in carbonate rock aquifers. Hydrogeology Journal, 18(6): 1303-1318.

Gradzinski, M., 2010. Factors controlling growth of modern tufa; results of a field experiment. Pedley, H.M., Rogerson, M. (Eds.), Tufas and Speleothems: Unravelling the Microbial and Physical Controls. Geological Society of London, London, pp. 143-191.

Herman, J.S., Hubbard, D.A., Virginia Division of Mineral Resources, 1990. Travertine-marl: stream deposits in Virginia. Virginia Division of Mineral Resources Publication. Virginia Division of Mineral Resources, Charlottesville, Va., $184 \mathrm{pp}$.

Herman, J.S., Lorah, M.M., 1986. Groundwater geochemistry in Warm River Cave, Virginia. The National Speological Society Bulletin, 48(2): 54-61.

Herman, J.S., Lorah, M.M., 1987. $\mathrm{CO}_{2}$ outgassing and calcite precipitation in Falling Spring Creek, Virginia, U.S.A. Chemical Geology, 62(3-4): 251-262.

Herman, J.S., Lorah, M.M., 1988. Calcite precipitation rates in the field: Measurement and prediction for a travertine-depositing stream. Geochimica et Cosmochimica Acta, 52(10): 2347-2355. 
Hobba, W.A., Fisher, D.W., Pearson, F.J., Chemerys, J.C., 1979. Hydrology and geochemistry of thermal springs of the Appalachians: Geohydrology of Geothermal Systems. United States Geology Survey, Washington, DC. Geological Survey Professional Paper, 1044-E. Holloway, S., Pearce, J.M., Hards, V.L., Ohsumi, T., Gale, J., 2006. Natural emissions of $\mathrm{CO}_{2}$ from the geosphere and their bearing on the geological storage of carbon dioxide. Energy, 32: 1194-1201.

Hondzo, M., Lyn, D., 1999. Quantified small-scale turbulence inhibits the growth of a green alga. Freshwater Biology, 41(1): 51-61.

Hubbard, D.A., Herman, J.S., 1991. Travertine marl: The "doughtnut-hole" of karst, Appalachian Karst - Proceedings of the Appalachian Karst Symposium, , Radford Virginia, pp. 59-64.

Hubbard, D.A., Herman, J.S., Bell, P.E., 1990. Speleogenesis in a travertine scarp: Observations of sulfide oxidation in the subsurface. Herman, J.S. (Ed.), Travertine Marl: Stream Deposits in Virginia, Reston, VA.

Inskeep, W.P., Bloom, P.R., 1986. Kinetics of calcite precipitation in the presence of watersoluble organic-ligands. Soil Science Society of America Journal, 50(5): 1167-1172.

Intergovernmental Panel on Climate Change, 2005. Carbon dioxide capture and storage, Intergovernmental Panel on Climate Change, New York, NY, pp. 431.

Jacboson, R.L., Usdowski, E., 1975. Geochemical controls on a calcite precipitating spring. Contributions to Mineralogy and Petrology, 51: 65-74.

Kawai, T., Kano, A., Hori, M., 2009. Geochemical and hydrological controls on biannual lamination of tufa deposits. Sedimentary Geology, 213(1-2): 41-50.

Keating, E.H., Fessenden, J., Kanjorski, N., Koning, D.J., Pawar, R., 2010. The impact of $\mathrm{CO}_{2}$ on shallow groundwater chemistry: Observations at a natural analog site and implications for carbon sequestration. Environmental Earth Sciences, 60(3): 521-536.

Konhauser, K., 2007. Microbial metabolism, Introduction to Geomicrobiology, 1. Blackwell Science Ltd, Malden, MA, pp. 36-92.

Lebron, I., Suarez, D.L., 1996. Calcite nucleation and precipitation kinetics as affected by dissolved organic matter at 25 degrees $\mathrm{C}$ and $\mathrm{pH}>7.5$. Geochimica et Cosmochimica Acta, 60(15): 2765-2776.

Lewicki, J.L., Birkholzer, J., Tsang, C.-F., 2007. Natural and industrial analogues for leakage of $\mathrm{CO}_{2}$ from storage reservoirs: identification of features, events, and processes and lessons learned. Environmental Geology, 52: 457-467.

Lindsay, S.S., Baedecker, M.J., 1988. Determination of Aqueous Sulfide in Contaminated and Natural Water Using the Methylene Blue Method. Collins, A.G., Johnson, A.I. (Eds.), Ground-Water Contaimination: Field Methods. American Society for Testing and Materials, Philadelphia, pp. 349-357.

Linsay, S.S., Baedecker, M.J., 1988. Determination of aqueous sulfide in contaminated and natural water using the methylene blue method. Collins, A.G., Johnson, A.I. (Eds.), Ground-water contaminaton: Field methods. American Society of Testing and Materials, Philadelphia, PA, pp. 349-357.

Lorah, M.M., Herman, J.S., 1988. The chemical evolution of a travertine-depositing stream: Geochemical processes and mass transfer reactions. Water Resources Research, 24(9): 1541-1552.

Lorah, M.M., Herman, J.S., 1990. Geochemical evolution and calcite precipitation rates in Falling Spring Creek, Virginia. Herman, J.S., Hubbard, D.A. (Eds.), Travertine-marl: Stream deposits in Virginia, Publication 101. Virginia Division of Mineral Resources, Charlottesville, VA, pp. 17-32. 
Lu, G., Zheng, C., Donahoe, R.J., Lyons, W.B., 2000. Controlling processes in a $\mathrm{CaCO}_{3}$ precipitating stream in Huanglong Natural Scenic District, Sichuan, China. Journal of Hydrology, 230: 34-54.

McColloch, J.S., Price, P.H., 1986. Springs of West Virginia, V-6A. West Virginia Geological and Economic Survey, Morgantown, WV, 493 pp.

Meyer, H., 1984. The influence of impurities on the growth rate of calcite. Journal of Crystal Growth, 66(3): 639-646.

Miglietta, F., Raschi, A., Bettarini, I., Resti, R., Selvi, F., 1993. Natural $\mathrm{CO}_{2}$ springs in Italy: a resource for examing long-term response of vegetation to rising atmospheric $\mathrm{CO}_{2}$ concentrations. Plant, Cell and Environment, 16: 873-878.

Newton, P.C., Bell, C.C., Clark, H., 1996. Carbon dioxide emissions from mineral springs in Northland and the potential of these sites for studying the effects of elevated carbon dioxide on pastures. New Zealand Journal of Agricultural Research, 39: 33-40.

Nordstrom, D.K., Wilde, F.D., 2005. 6.5 Reduction oxidation potential (electrode method), National Field Manual for the Collection of Water-Quality Data, 9. United States Geological Survey, Reston, VA.

Okumura, T., Takashima, C., Shiraishi, F., Akmaluddin, Kano, A., 2012. Textural transition in an aragonite travertine formed under various flow conditions at Pancuran Pitu, Central Java, Indonesia. Sedimentary Geology, 265-266: 195-209.

Orndorff, R.C., Epstein, J.B., Geological Society of Washington., 1994. A structural and stratigraphic excursion through the Shenandoah Valley, northern Virginia. United States Geological Survey, Reston, VA. Open File Report, 94-573.

Pentecost, A., 2005. Travertine, 1. Springer, Heidelberg, NY, 446 pp.

Perry, L.D., Costain, J.K., Geiser, P.A., 1979. Heat-flow in western Virginia and a model for the origin of thermal springs in the folded Appalachians. Journal of Geophysical Research, 84: 6875-6883.

Plummer, L.N., Wigley, T.M.L., Parkhurst, D.L., 1978. Kinetics of calcite dissolution in $\mathrm{CO}_{2}$ water systems at 5 degrees $\mathrm{C}$ to 60 degrees $\mathrm{C}$ and 0.0 to $1.0 \mathrm{~atm} \mathrm{CO}_{2}$. American Journal of Science, 278(2): 179-216.

Rader, E.K., Thomas M. Gathright, I., 1984. Geologic environment of the thermal springs of western Virginia, Virginia Geological Field Conference: Stratigraphy and structure in the thermal springs area of the western anticlines. College of William and Mary, pp. 13-15.

Reddy, M.M., 1977. Crystallization of calcium carbonate in the presence of trace concentrations of phosphorus containing anions: Inhibition by phosphate and glycerophosphate ions at pH 8.8 and 25 degrees C. Journal of Crystal Growth, 41(2): 287-295.

Reddy, M.M., 1983. Characterization of calcite dissolution and precipitation using an improved experimental technique. Pe'trologie des alte'rations et des sols, 71: 109-117.

Reddy, M.M., 1986. Effect of magnesium ions on calcium carbonate nucleation and crystal growth in dilute aqueous solutions at 25 C. Mumpton, F.A. (Ed.), Studies in Diagensis, U.S. Geological Survey Bulletin 1578. United States Geological Survey, Denver, Colorado, pp. 169-182.

Reddy, M.M., Plummer, L.N., Busenberg, E., 1981. Crystal growth of calcite from calcium bicarbonate solutions at constant $\mathrm{P}_{\mathrm{CO} 2}$ and 25 degrees $\mathrm{C}$ : a test of a calcite dissolution model. Geochimica et Cosmochimica Acta, 45(8): 1281-1289.

Reeves, F., 1932. Thermal springs of Virginia. Virginia Geological Survey, Richmond, VA. Bulletin No. 36 . 
Rogie, J.D., Kerrick, D.M., Sorey, M.L., Chiodini, G., Galloway, D.L., 2001. Dynamics of carbon dioxide emission at Mammoth Mountain, California. Earth and Planetary Science Letters, 188(3-4): 535-541.

Sherwood, W.C., 1977. Geology of Little North Mountain and the central Shenandoah Valley, Virginia Geology Field Conference, Annual Virginia Geology Conference. James Madison University, Dept. of Geology, Harrisonburg, VA, pp. 1-42.

Siegel, D.I., Lesniak, K.A., Stute, M., Frape, S., 2004. Isotopic geochemistry of the Saratoga springs: Implications for the origin of solutes and source of carbon dioxide. Geology, 32(3): 257-260.

Stoessell, R.K., 1992. Effects of sulfate reduction on $\mathrm{CaCO}_{3}$ dissolution and precipitation in mixing-zone fluids. Journal of Sedimentary Petrology, 62(5): 873-880.

Stookey, L.L., 1970. Ferrozine - A new spectrophotometric reagent for iron. Analytical Chemistry, 42(7): 779-781.

Stumm, W., Morgan, J.J., 1996. Aquatic chemistry: chemical equilibria and rates in natural waters, 2, Stumm, W. Wiley-Interscience, New York, 1022 pp.

Sturms, J.S., 2008. Surficial mapping and kinematic modeling of the St. Clair Thrust Fault, Monroe County, West Virginia. M.S. Thesis, West Virginia University, Morgantown, WV, $84 \mathrm{pp}$.

Takano, B., Asano, Y., Watanuki, K., 1980. Characterization of sulfate ion in travertine. Contributions to Mineralogy and Petrology, 72(2): 197-203.

United States Department of Energy, 2010. Carbon Sequestration. Fossil Energy Office of Communications.

[http://www.netl.doe.gov/technologies/carbon seq/overview/index.html] January 2010.

United States Environmental Protection Agency, 1983. Sulfide (Colorimetric, Methylene Blue), Methods for the chemical analysis of water and wastes 376.2. United States Environmental Protection Agency, Cincinnatti, $\mathrm{OH}$.

Usdowski, E., Hoefs, J., Menschel, G., 1979. Relationship between ${ }^{13} \mathrm{C}$ and ${ }^{18} \mathrm{O}$ fractionation and changes in major element composition in a recent calcite-depositing spring - A model of chemical variations with inorganic $\mathrm{CaCO}_{3}$ precipitation. Earth and Planetary Science Letters, 42(2): 267-276.

Vesper, D.J., Edenborn, H.M., 2012. Determination of free $\mathrm{CO}_{2}$ in emergent groundwaters using a commercial beverage carbonation meter. Journal of Hydrology, 438-439: 148-155.

Virginia Department of Mines Minerals and Energy, 2003. Digital representation of the 1993 geologic map of Virginia - expanded explanation, Virginia Department of Mines, Minerals, and Energy, Charlottesville, VA, pp. 88.

Vuataz, F.D., Goff, F., 1986. Isotope geochemistry of thermal and nonthermal waters in the Valles Caldera, Jemez Mountains, Northern New-Mexico. Journal of Geophysical Research-Solid Earth and Planets, 91(2): 1835-1853.

Wilkes, G.P., 2002. Geologic map of the Virginia portion of the Lewisburg $30 \times 60$ minute quadrangle, Virginia Department of Mines, Minerals, and Energy. Virginia Department of Mines, Minerals, and Energy, Reston, VA.

Williams, A.J., Andersen, C.B., Lewis, G.P., 2009. Evaluating the effects of sample processing treatments on alkalinity measurements. Journal of Hydrology, 377(3-4): 455-464.

Zaihua, L., Svensson, U., Dreybrodt, W., Daoxian, Y., Buhmann, D., 1995. Hydrodynamic control of inorganic calcite precipitation in Huanglong Ravine, China: Field measurements and theoretical prediction of deposition rates. Geochimica et Cosmochimica Acta 59(15): 3087-3097. 
Zhang, D.D., Zhang, Y.J., Zhu, A., Cheng, X., 2001. Physical mechanisms of river waterfall tufa formation. Journal of Sedimentary Research, 71(1): 205-216. 
Appendices 


\section{Appendix A - Figures}


Figure $1 \mathrm{~A}$ - Lewisburg 30 x 60 Quadrangle (Wilkes, 2002)

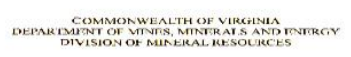

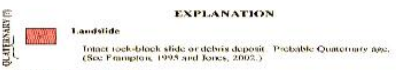
[ar and

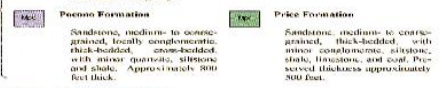

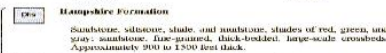

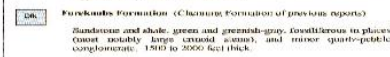

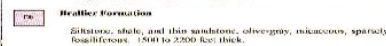

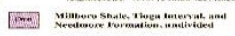

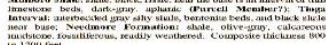

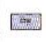

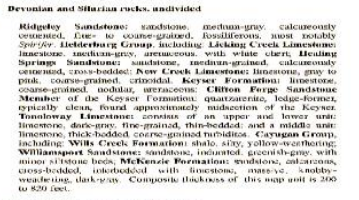
00 -

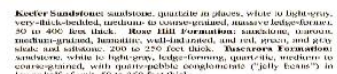
미 ㄴ.

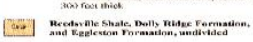

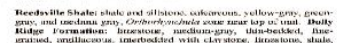

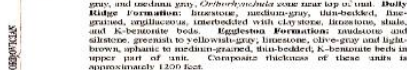

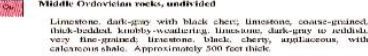

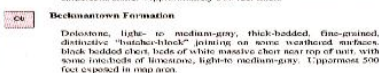

GEOLOGIC MAP OF THE VIRGINIA PORTION OF
THE LEWISBURG 30 X 60 MINUTE QUADRANGLE

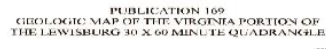

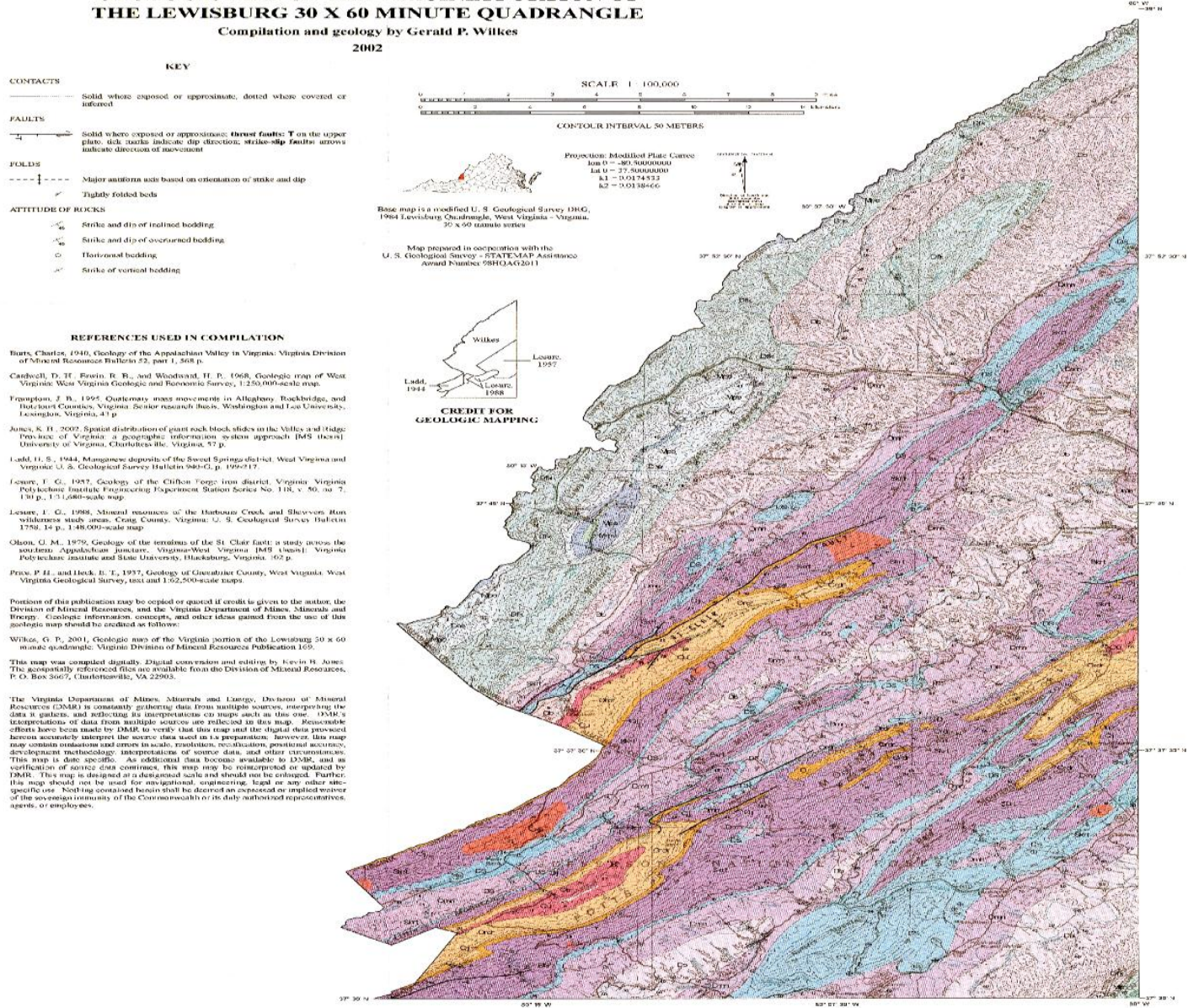


Figure 2A - Fault splay breccia

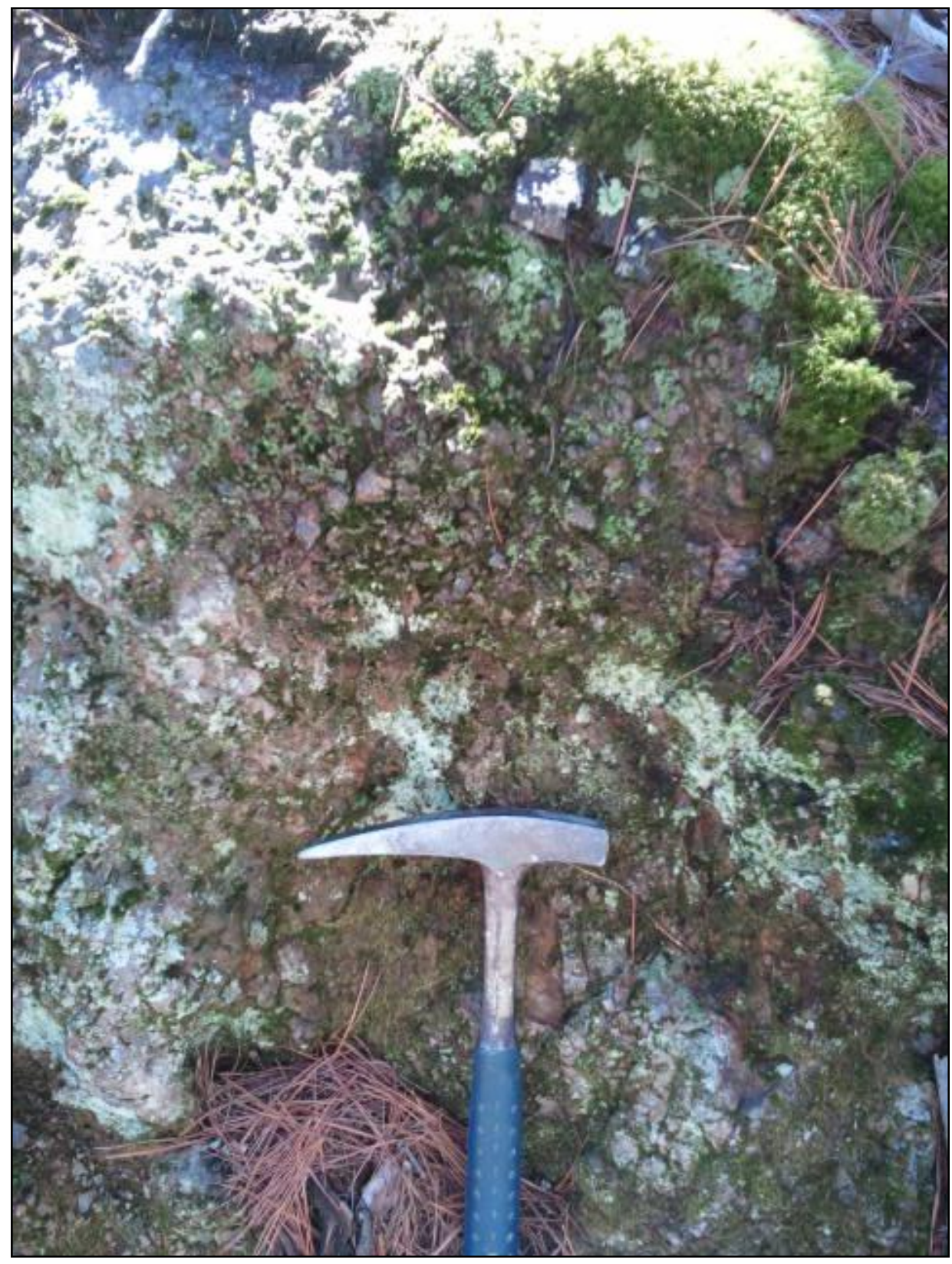


Appendix B - Data 
Table 1B - Expanded site descriptions

\begin{tabular}{|c|c|c|c|c|c|c|c|}
\hline Site Name & Sample ID & $\begin{array}{l}\text { Short } \\
\text { Name }\end{array}$ & $\begin{array}{c}\text { (n) } \\
\text { Samples }\end{array}$ & $\begin{array}{c}\text { Travertine } \\
\text { plates }\end{array}$ & UTM-E & UTM-N & Description \\
\hline $\begin{array}{l}\text { Old Sweet } \\
\text { Spring }\end{array}$ & OLDSWT & "Old Sweet & 3 & Yes & 567060 & 4165036 & $\begin{array}{l}\text { Old Sweet Spring emerges in a sand and gravel bottomed pool that is } \\
\text { approximately } 15 \times 15 \mathrm{~m} \text {. The pool is in on the flank of the Homestead } \\
\text { Resort which has since been closed. The pool discharges into a small } \\
\text { stream that drains into the larger Sweet Springs Creek. } \\
\text { Water emerges from point locations in the pool as evidenced by sand }\end{array}$ \\
\hline
\end{tabular}
boils and $\mathrm{CO}_{2}$ plumes. The thermal nature of the waters facilitates microbial and algal growth year-around; algal mats persist in the winter.

$\begin{array}{lllllll}\text { Cesspool Cave } & \text { CESSPE } & \text { Cesspool } & 1 & \text { No } & 571092 & 4168287 \\ \text { Spring } & & & & & \end{array}$

Cesspool Cave is located within the Sawmill Falls Escarpment, which is a Quaternary travertine complex that is perpendicular to Sweet Springs Creek. Cesspool cave has formed within the travertine by the process of acid dissolution induced by bacterial metabolization of $\mathrm{H}_{2} \mathrm{~S}$ to $\mathrm{H}_{2} \mathrm{SO}_{4}{ }^{2-}$ (Engel et al., 2001; Hubbard et al., 1990). The waters in the cave have high concentrations of $\mathrm{H}_{2} \mathrm{~S}$, with the highest levels being recorded at over $7 \mathrm{mg} / \mathrm{L}$. The source of $\mathrm{H}_{2} \mathrm{~S}$ has been debated, but it is likely that organic shales below the cave contribute sulfur via iron sulfide mineral oxidation and organic degradation (Hubbard et al., 1990).

The cave is approximately 20 meters in length and 12 meters at its widest (Figure A5) (Hubbard et al., 1990). The flowstone at the base of the cave wall shows signs of acidic dissolution and gypsum precipitation.

$\begin{array}{lllllll}\text { Sweet } & \text { CHAL } & \text { Chalybeate } & 3 & \text { Yes } & 567138 & 4166368 \\ \text { Chalybeate } & & & & & \\ \text { Spring } & & & & \end{array}$

Sweet Chalybeate spring is situated at the head of a small ravine that is truncated by a road cut. The spring emerges from an open cavern that is formed in travertine. At emergence, the spring waters are channeled via a concrete aqueduct to pools on the property and eventually into Sweet Springs Creek, after traveling approximately 40 meters. Iron hydroxides are present along the entire length of the discharge and culminate in extensive deposits in the pools. The final pathway of discharge from the pools is a pipe that is submerged in the creek.

The travertine deposits show extensive weathering and there appears to be no active precipitation of travertine near the spring. 
Table 1B - Expanded site descriptions

\begin{tabular}{|c|c|c|c|c|c|c|c|}
\hline Site Name & Sample ID & $\begin{array}{l}\text { Short } \\
\text { Name }\end{array}$ & $\begin{array}{c}\text { (n) } \\
\text { Samples }\end{array}$ & $\begin{array}{c}\text { Travertine } \\
\text { plates }\end{array}$ & UTM-E & UTM-N & Description \\
\hline $\begin{array}{l}\text { Sweet } \\
\text { Chalybeate } \\
2.0 \mathrm{C} \\
\text { Sweet } \\
\text { Chalybeate } \\
2.0 \mathrm{M}\end{array}$ & CHAL2.0M & $\begin{array}{c}\text { Chalybeate } \\
2.0 \mathrm{M}\end{array}$ & 3 & No & 567138 & 4166390 & $\begin{array}{l}\text { Comprised of two distinct waters that emerge in the same pool. The } \\
\text { first spring to enter the pool is a cold spring that appears to be a } \\
\text { meteorically controlled discharge. The second spring emerges in the } \\
\text { center of the pool as a seep, as evidence by both } \mathrm{CO}_{2} \text { plumes and } \\
\text { temperature gradient in the pool. } \\
\text { The pool is approximately } 3 \times 2 \text { meters and outflows into corrugated } \\
\text { pipe. There is little in the way of rock exposure as the area has been } \\
\text { reworked multiple times by the landowners. The pool shows signs of } \\
\text { active algal growth but no travertine precipitation is visible within or } \\
\text { along the spring discharge. After discharging into the pipe the flow is } \\
\text { channelized until the confluence with Sweet Springs Creek. }\end{array}$ \\
\hline
\end{tabular}

$\begin{array}{llcclrr}\text { Sweet Springs } & \text { SWCRK3740 } & \text { CREEK } & 2 & \text { Yes } & 567129 & 4166358 \\ \text { Creek } 3740 & & 3740 & & & & \end{array}$

Located in Sweet Springs Creek above the input of Sweet Chalybeate Spring and approximately 5 meters from the initiation of rapids that precede the input of the spring Figure A3. This site was chosen because it marks the initiation of visible precipitation of travertine within the stream.

The stream is 4.8 meters wide at this point and at its deepest reach is never more than 0.5 meters. Active travertine precipitation and algal growth is visible on the entirety of the channel bottom. Samples were taken on the left bank facing downstream, under the shade of a large tree; travertine plates and temperature sensors were also installed at this point.

$\begin{array}{lcccccc}\text { Sweet Springs } & \text { SWCRK3890 } & \text { CREEK } & 2 & \text { Yes } & 567109 & 4166488 \\ \begin{array}{l}\text { Creek } 3890 \\ \text { meters }\end{array} & 3890 & & & & \end{array}$

Located in Sweet Springs Creek directly below the input of Sweet Chalybeate Spring Figure 3A. The site was chosen because of its distance away from the input and clear channel width.

The channel is 3.7 meters wide and the deepest section is approximately 0.5 meters. No precipitation of travertine is evident and there is little in the way of algal growth. Samples were taken in the deepest section and represent the area of highest flow. Plates were installed at the same locality, which is afforded considerable shade. 
Table 1B - Expanded site descriptions

\begin{tabular}{|c|c|c|c|c|c|c|c|}
\hline Site Name & Sample ID & $\begin{array}{l}\text { Short } \\
\text { Name }\end{array}$ & $\begin{array}{c}(\mathrm{n}) \\
\text { Samples }\end{array}$ & $\begin{array}{c}\text { Travertine } \\
\text { plates }\end{array}$ & UTM-E & UTM-N & Description \\
\hline $\begin{array}{l}\text { Sweet Springs } \\
\text { Creek } 4010 \\
\text { meters }\end{array}$ & SWCRK4010 & $\begin{array}{c}\text { CREEK } \\
4010\end{array}$ & 2 & Yes & 567099 & 4166704 & $\begin{array}{l}\text { Located in Sweet Springs Creek } 120 \text { meters downstream of SW3890 } \\
\text { and approximately } 50 \text { meters before the input of Sweet Chalybeate } \\
\text { 2.0. This site was selected because it facilitated access, discharge } \\
\text { measurement, and ample stream length to ensure mixing of the stream } \\
\text { and spring waters. } \\
\text { The channel is approximately } 5.3 \text { meters wide and no deeper than } \\
0.66 \text { meters through the section. The banks show considerable erosion } \\
\text { that is likely a product of agriculture. Plates were placed at the right } \\
\text { bank edge in such a manner as to avoid any interference from said } \\
\text { agriculture. The area is well shaded and provides ample water depth. }\end{array}$ \\
\hline
\end{tabular}

\begin{tabular}{|c|c|c|c|c|c|c|c|}
\hline $\begin{array}{l}\text { Sweet Springs } \\
\text { Creek } 4120 \\
\text { meters }\end{array}$ & SWCRK4120 & $\begin{array}{c}\text { CREEK } \\
4120\end{array}$ & 2 & Yes & 567149 & 4166983 & $\begin{array}{l}\text { Located below the input of Sweet Chalybeate } 2.0 \text {. This site was } \\
\text { selected because it was the end of property access and it provides } \\
\text { considerable distance from the spring input to ensure complete mixing. } \\
\text { The channel is nearly the same dimensions as SW } 4010 \text { except the } \\
\text { addition of a large tree that acts as a breakwater on the channel bank. } \\
\text { Plates were placed away from this tree and in a shady stream } \\
\text { portion. The banks are destabilized in the portion of the stream due to } \\
\text { agriculture and animal grazing paths. Care was taken to avoid putting } \\
\text { the plates in the direct path of livestock. }\end{array}$ \\
\hline
\end{tabular}

Sweet Springs $\quad$ SWCRK6115 $\quad$ CREEK $2 \quad$ Yes $567541 \quad 4168855 \quad$ Located before the Sawmill Falls, which is a product of Sweet Springs

Creek 6115

meters along the length of Sweet Springs Creek.

The channel is 10 meters wide and approaches a maximum depth of 1 meter. Abundant cobblestones and boulders litter the channel; care was taken to avoid these obstacles during plate emplacement and discharge measurements. The channel is heavily influenced by active travertine growth and algal growth is evident on most channel surfaces. Travertine plates were placed near the left bank of the channel under the shade of a large tree. 
Table 1B - Expanded site descriptions

\begin{tabular}{|c|c|c|c|c|c|c|c|}
\hline Site Name & Sample ID & $\begin{array}{l}\text { Short } \\
\text { Name }\end{array}$ & $\begin{array}{c}\text { (n) } \\
\text { Samples }\end{array}$ & $\begin{array}{c}\text { Travertine } \\
\text { plates }\end{array}$ & UTM-E & UTM-N & Description \\
\hline $\begin{array}{l}\text { Sweet Springs } \\
\text { Creek } 6150 \\
\text { meters }\end{array}$ & SWCRK6150 & $\begin{array}{c}\text { CREEK } \\
6150\end{array}$ & 1 & Yes & 567531 & 4168883 & $\begin{array}{l}\text { Located at the base of Sawmill falls. The site was selected because it } \\
\text { is the stream point where theoretical } \mathrm{CO}_{2} \text { exsolution should be the most } \\
\text { extreme after the waters going over falls. } \\
\text { The falls terminate in a pool that is approximately } 25 \text { meters wide } \\
\text { and } 15 \text { meters long. The pool is extremely deep compared to the rest of } \\
\text { the stream, with depths over } 10 \text { meters. Porous travertine deposits are } \\
\text { present on all surfaces below the water line. Travertine plates were } \\
\text { placed at the left edge of the pool at a depth of approximately } 4 \text { meters; } \\
\text { this depth provides concealment and creates a degree of shade as in the } \\
\text { other sites. }\end{array}$ \\
\hline
\end{tabular}


Table 2B - Field parameters

\begin{tabular}{|c|c|c|c|c|c|c|c|}
\hline Sample ID & Date & $\begin{array}{c}\text { Temperature } \\
\left(\mathrm{C}^{\circ}\right) \\
\end{array}$ & $\begin{array}{c}\mathrm{SC} \\
(\mu S / \mathrm{cm})\end{array}$ & DO (\%) & $\begin{array}{l}\text { ORP } \\
(\mathrm{mV})\end{array}$ & $\mathrm{pH}$ & $\begin{array}{c}\text { Alkalinity } \\
\text { (meq/L) }\end{array}$ \\
\hline $\mathrm{CHAL}^{*}$ & $8 / 10 / 10$ & 23.3 & 1868 & 14 & na & 6.25 & 12.6 \\
\hline OLDSWT* & $8 / 10 / 10$ & 22.7 & 1692 & 3.2 & na & 6.31 & 11.6 \\
\hline $\mathrm{CHAL}^{*}$ & $9 / 25 / 10$ & 23.4 & 1902 & 12 & 120 & 6.34 & 12.8 \\
\hline OLDSWT* & $9 / 25 / 10$ & 22.8 & 1712 & 14 & 86 & 6.42 & 11.4 \\
\hline SPELM* & $9 / 25 / 10$ & 12.5 & 441 & 56 & 140 & 7.24 & 4.36 \\
\hline $\mathrm{CHAL}^{*}$ & $11 / 20 / 10$ & 23.4 & 1911 & 13 & 130 & 6.34 & 10.9 \\
\hline OLDSWT* & $11 / 20 / 10$ & 22.3 & 1710 & 15 & 11 & 6.39 & 11.6 \\
\hline CESSPE* & $11 / 21 / 10$ & 12.8 & 932 & 6.2 & -310 & 6.81 & 5.16 \\
\hline CREEK6115* & $11 / 21 / 10$ & 13.1 & 1142 & 86 & 2.0 & 7.71 & na \\
\hline OLDSWT & $5 / 27 / 11$ & 22.2 & 1682 & 26 & 49 & 6.32 & 10.8 \\
\hline $\mathrm{CHAL}$ & $5 / 27 / 11$ & 22.9 & 1821 & 17 & 70 & 6.29 & 11.6 \\
\hline CREEK3740 & $5 / 27 / 11$ & 15.9 & 396 & 110 & 130 & 7.58 & 3.09 \\
\hline CREEK3890 & $5 / 27 / 11$ & 18.2 & 458 & 110 & 130 & 7.65 & 3.22 \\
\hline CREEK6115 & $5 / 28 / 11$ & 18.6 & 610 & 40 & -34 & 7.15 & 5.00 \\
\hline CHAL2.0M* & $5 / 28 / 11$ & 19.0 & 1366 & 27 & 45 & 6.34 & 9.66 \\
\hline CHAL2.0C* & $5 / 28 / 11$ & 16.1 & 980 & 41 & 81 & 6.42 & 7.38 \\
\hline CREEK4010 & $5 / 29 / 11$ & 15.9 & 574 & 33 & 2 & 6.94 & 4.54 \\
\hline CREEK4120 & $5 / 29 / 11$ & 15.1 & 583 & 78 & 110 & 6.82 & 4.32 \\
\hline SPELM* & $6 / 28 / 11$ & 12.5 & 429 & 52 & 110 & 7.17 & 4.43 \\
\hline OLDSWT* & $6 / 28 / 11$ & 22.7 & 1704 & 17 & 130 & 6.32 & 12.9 \\
\hline $\mathrm{CHAL}^{*}$ & $6 / 28 / 11$ & 23.2 & 1788 & 8.7 & -37 & 6.22 & 12.0 \\
\hline CHAL2.0C* & $6 / 28 / 11$ & 18.9 & 1430 & 14 & -35 & 6.28 & 10.3 \\
\hline CHAL2.0M* & $6 / 28 / 11$ & 21.1 & 1656 & 7.0 & -52 & 6.39 & 10.5 \\
\hline CESSPE* & $6 / 28 / 11$ & 13.0 & 934 & 10 & -2.5 & 6.91 & 7.68 \\
\hline OLDSWT & $8 / 1 / 11$ & 22.7 & 1709 & 7.1 & 73 & 6.62 & 11.0 \\
\hline $\mathrm{CHAL}$ & $8 / 2 / 11$ & 23.3 & 1860 & 8.8 & -100 & 6.24 & 12.2 \\
\hline CREEK3740 & $8 / 2 / 11$ & 16.2 & 792 & 54 & -77 & 7.44 & 5.75 \\
\hline CREEK3890 & $8 / 2 / 11$ & 17.2 & 886 & 48 & -68 & 7.13 & 6.37 \\
\hline CREEK4010 & $8 / 2 / 11$ & 19.9 & 1052 & 35 & -49 & 6.75 & 7.28 \\
\hline CREEK4120 & $8 / 2 / 11$ & 19.4 & 1079 & 44 & -51 & 6.86 & 7.53 \\
\hline CHAL2.0C & $8 / 3 / 11$ & 21.1 & 1693 & 5.7 & -97 & 6.45 & 10.9 \\
\hline CHAL2.0M & $8 / 3 / 11$ & 21.3 & 1721 & 5.4 & -35 & 6.38 & 10.7 \\
\hline CESSPE & $8 / 3 / 11$ & 13.4 & 951 & 5.1 & -240 & 6.91 & 8.19 \\
\hline CREEK6115 & $8 / 3 / 11$ & 20.1 & 1090 & 42 & -58 & 7.65 & 7.26 \\
\hline CREEK6150 & $8 / 3 / 11$ & 20.3 & 1074 & 40 & 58 & 8.11 & 7.45 \\
\hline
\end{tabular}

Notes: *Denotes chemical samples without travertine precipitation data; na - data not available 
Table 3B - Cation Data

\begin{tabular}{|c|c|c|c|c|c|c|c|c|c|c|c|c|c|}
\hline Sample ID & Date & $\begin{array}{c}\mathrm{Ba} \\
(\mu \mathrm{g} / \mathrm{L})\end{array}$ & $\begin{array}{c}\mathrm{Ca} \\
(\mathrm{mg} / \mathrm{L})\end{array}$ & $\begin{array}{c}\mathrm{Fe} \\
(\mu \mathrm{g} / \mathrm{L})\end{array}$ & $\begin{array}{c}\mathrm{K} \\
(\mathrm{mg} / \mathrm{L})\end{array}$ & $\begin{array}{c}\mathrm{Li} \\
(\mu \mathrm{g} / \mathrm{L})\end{array}$ & $\begin{array}{c}\mathrm{Mg} \\
(\mathrm{mg} / \mathrm{L})\end{array}$ & $\begin{array}{c}\mathrm{Mn} \\
(\mu \mathrm{g} / \mathrm{L})\end{array}$ & $\begin{array}{c}\mathrm{Na} \\
(\mathrm{mg} / \mathrm{L})\end{array}$ & $\begin{array}{c}\mathrm{S} \\
(\mathrm{mg} / \mathrm{L})\end{array}$ & $\begin{array}{c}\mathrm{Si} \\
(\mathrm{mg} / \mathrm{L})\end{array}$ & $\begin{array}{c}\mathrm{Sr} \\
(\mathrm{mg} / \mathrm{L})\end{array}$ & $\begin{array}{c}\mathrm{Zn} \\
(\mu \mathrm{g} / \mathrm{L})\end{array}$ \\
\hline CHAL & $8 / 10 / 10$ & 40 & 287.5 & 183 & 27.1 & 210 & 58.2 & 26 & 20.1 & 156.6 & 6.2 & 4.3 & 19 \\
\hline OLDSWT & $8 / 10 / 10$ & 33 & 267.9 & 33 & 24.1 & 178 & 56.3 & 20 & 17.8 & 146.1 & 5.8 & 3.9 & 15 \\
\hline CHAL (D) & $9 / 25 / 10$ & 54 & 310.8 & 196 & 32.9 & 297 & 58.0 & 29 & 20.9 & 154.5 & 6.6 & 4.8 & 17 \\
\hline CHAL & $9 / 25 / 10$ & 36 & 324.0 & 186 & 30.9 & 278 & 55.8 & 28 & 21.5 & 141.0 & 6.3 & 5.0 & 6 \\
\hline OLDSWT & $9 / 25 / 10$ & 32 & 278.2 & 30 & 27.3 & 238 & 53.3 & 17 & 16.7 & 134.4 & 5.9 & 4.1 & 6 \\
\hline SPELM & $9 / 25 / 10$ & 50 & 59.0 & 7 & 2.3 & $<\mathrm{DL}$ & 17.7 & 1 & 1.4 & $<\mathrm{DL}$ & 3.7 & 0.2 & 4 \\
\hline CHAL & $11 / 20 / 10$ & 42 & 340.6 & 206 & 33.1 & 276 & 62.1 & 29 & 23.9 & 159.2 & 6.9 & 5.3 & 11 \\
\hline OLDSWT & $11 / 20 / 10$ & 40 & 290.2 & 16 & 26.6 & 224 & 55.0 & 15 & 20.2 & 140.2 & 6.2 & 4.3 & 11 \\
\hline CESSPE & $11 / 21 / 10$ & 105 & 161.5 & 29 & 5.3 & 35 & 16.9 & 328 & 8.9 & 41.1 & 6.9 & 1.3 & 4 \\
\hline CREEK6115 & $11 / 21 / 10$ & 88 & 177.1 & 9 & 14.4 & 118 & 10.8 & 36 & 11.3 & 78.3 & 4.4 & 2.3 & 12 \\
\hline
\end{tabular}

Notes: na - data not available; $<\mathrm{DL}-$ below detection limit 
Table 3B Continued - Cation Data

\begin{tabular}{|c|c|c|c|c|c|c|c|c|c|c|c|c|c|}
\hline Sample ID & Date & $\begin{array}{c}\mathrm{Ba} \\
(\mu \mathrm{g} / \mathrm{L})\end{array}$ & $\begin{array}{c}\mathrm{Ca} \\
(\mathrm{mg} / \mathrm{L})\end{array}$ & $\begin{array}{c}\mathrm{Fe} \\
(\mu \mathrm{g} / \mathrm{L})\end{array}$ & $\begin{array}{c}\mathrm{K} \\
(\mathrm{mg} / \mathrm{L})\end{array}$ & $\begin{array}{c}\mathrm{Li} \\
(\mu \mathrm{g} / \mathrm{L})\end{array}$ & $\begin{array}{c}\mathrm{Mg} \\
(\mathrm{mg} / \mathrm{L})\end{array}$ & $\begin{array}{c}\mathrm{Mn} \\
(\mu \mathrm{g} / \mathrm{L})\end{array}$ & $\begin{array}{c}\mathrm{Na} \\
(\mathrm{mg} / \mathrm{L})\end{array}$ & $\begin{array}{c}\mathrm{S} \\
(\mathrm{mg} / \mathrm{L})\end{array}$ & $\begin{array}{c}\mathrm{Si} \\
(\mathrm{mg} / \mathrm{L})\end{array}$ & $\begin{array}{c}\mathrm{Sr} \\
(\mathrm{mg} / \mathrm{L})\end{array}$ & $\begin{array}{c}\mathrm{Zn} \\
(\mu \mathrm{g} / \mathrm{L})\end{array}$ \\
\hline OLDSWT & $5 / 27 / 11$ & 34 & 280.0 & 0 & 23.0 & 195 & 32.0 & 9 & 17.7 & 144.0 & 5.7 & 3.9 & 11 \\
\hline $\mathrm{CHAL}$ & $5 / 27 / 11$ & 65 & 294.9 & 197 & 26.0 & 191 & 26.3 & 14 & 19.6 & 157.3 & 5.6 & 4.3 & 17 \\
\hline CREEK3740 & $5 / 27 / 11$ & 114 & 73.0 & $<\mathrm{DL}$ & 3.1 & 18 & 8.2 & 25 & 3.9 & 16.7 & 2.8 & 0.4 & 25 \\
\hline CREEK3890 & $5 / 28 / 11$ & 87 & 60.3 & 33 & 2.8 & 12 & 6.9 & 33 & 3.2 & 12.1 & 2.2 & 0.4 & 39 \\
\hline CREEK6115 & $5 / 28 / 11$ & 112 & 93.0 & 11 & 5.0 & 35 & 10.8 & 35 & 5.2 & 31.3 & 3.2 & 0.8 & 34 \\
\hline CHAL2.0M & $5 / 28 / 11$ & 118 & 251.3 & 178 & 17.0 & 156 & 21.4 & 18 & 12.5 & 137.2 & 5.5 & 3.6 & 48 \\
\hline CHAL2.0C & $5 / 28 / 11$ & 115 & 231.1 & 236 & 15.2 & 130 & 22.8 & 20 & 11.3 & 118.6 & 5.0 & 3.2 & 46 \\
\hline CREEK4010 & $5 / 29 / 11$ & 26 & 98.4 & 9 & 5.1 & 34 & 10.4 & 26 & 4.8 & 28.5 & 3.1 & 0.8 & 5 \\
\hline CREEK4120 & $5 / 29 / 11$ & 105 & 94.3 & 3 & 4.7 & 32 & 10.1 & 24 & 4.9 & 27.1 & 2.9 & 0.7 & 37 \\
\hline OLDSWT & $6 / 28 / 11$ & 72 & 295.1 & $<\mathrm{DL}$ & 25.7 & 195 & 60.7 & 13 & 19.8 & 155.2 & 5.5 & 4.3 & 7 \\
\hline $\mathrm{CHAL}$ & $6 / 28 / 11$ & 30 & 284.0 & 162 & 26.5 & 215 & 55.8 & 23 & 19.7 & 150.9 & 5.8 & 4.2 & 4 \\
\hline CHAL2.0C & $6 / 28 / 11$ & 50 & 250.5 & 208 & 18.1 & 156 & 49.8 & 19 & 13.2 & 142.4 & 5.2 & 3.7 & 9 \\
\hline CHAL2.0M & $6 / 28 / 11$ & 31 & 271.1 & 179 & 20.1 & 181 & 54.5 & 22 & 14.2 & 156.9 & 5.6 & 4.1 & 5 \\
\hline CESSPE & $6 / 28 / 11$ & 176 & 149.4 & 15 & 4.9 & 22 & 16.7 & 299 & 10.8 & 42.3 & 6.2 & 1.2 & 6 \\
\hline SPELM & $6 / 28 / 11$ & 72 & 58.2 & $<D L$ & 2.0 & $<\mathrm{DL}$ & 16.4 & 0 & 1.8 & 6.6 & 3.5 & 0.2 & 11 \\
\hline OLDSWT & $8 / 1 / 11$ & 189 & 286.3 & 101 & 36.2 & $<\mathrm{DL}$ & 86.2 & 22 & 29.2 & - & - & - & 77 \\
\hline $\mathrm{CHAL}$ & $8 / 2 / 11$ & 51 & 345.9 & 242 & 27.7 & $<\mathrm{DL}$ & 59.2 & 25 & 21.4 & - & - & - & 12 \\
\hline CREEK3740 & $8 / 2 / 11$ & 37 & 127.0 & 41 & 7.4 & $<\mathrm{DL}$ & 23.6 & 34 & 6.1 & - & - & - & 10 \\
\hline CREEK3890 & $8 / 2 / 11$ & 118 & 144.5 & 249 & 9.0 & $<\mathrm{DL}$ & 26.5 & 29 & 7.7 & - & - & - & 45 \\
\hline CREEK4010 & $8 / 2 / 11$ & 40 & 169.8 & 47 & 11.3 & $<\mathrm{DL}$ & 30.9 & 25 & 8.7 & - & - & - & 12 \\
\hline CREEK4120 & $8 / 2 / 11$ & 35 & 179.6 & 60 & 11.8 & $<\mathrm{DL}$ & 31.8 & 40 & 8.9 & - & - & - & 46 \\
\hline CESSPE & $8 / 3 / 11$ & 131 & 175.5 & 68 & 5.2 & $<\mathrm{DL}$ & 17.1 & 342 & 10.0 & - & - & - & 12 \\
\hline CHAL2.0C & $8 / 3 / 11$ & 41 & 317.6 & 298 & 20.2 & $<\mathrm{DL}$ & 31.2 & 26 & 14.8 & - & - & - & 17 \\
\hline CHAL2.0M & $8 / 3 / 11$ & 32 & 327.4 & 282 & 20.9 & $<\mathrm{DL}$ & 31.5 & 25 & 15.1 & - & - & - & 9 \\
\hline CREEK6115 & $8 / 3 / 11$ & 36 & 181.6 & 40 & 11.5 & $<\mathrm{DL}$ & 31.7 & 21 & 8.7 & - & - & - & 7 \\
\hline CREEK6150 (D) & $8 / 3 / 11$ & 105 & 178.9 & $<\mathrm{DL}$ & 11.4 & $<\mathrm{DL}$ & 55.3 & 18 & 8.5 & - & - & - & 8 \\
\hline CREEK6150 & $8 / 3 / 11$ & 38 & 182.0 & 36 & 11.4 & $<\mathrm{DL}$ & 56.1 & 15 & 9.0 & - & - & - & 31 \\
\hline
\end{tabular}

na - data not available
$<\mathrm{DL}-$ Below detection limit 
Table 4B - Anion Data

\begin{tabular}{|c|c|c|c|c|c|}
\hline Sample ID & Date & $\begin{array}{c}\mathrm{Fl} \\
(\mathrm{mg} / \mathrm{L}) \\
\end{array}$ & $\begin{array}{c}\mathrm{Cl} \\
(\mathrm{mg} / \mathrm{L}) \\
\end{array}$ & $\begin{array}{c}\mathrm{SO}_{4} \\
(\mathrm{mg} / \mathrm{L}) \\
\end{array}$ & $\begin{array}{c}\mathrm{NO}_{3} \\
(\mathrm{mg} / \mathrm{L}) \\
\end{array}$ \\
\hline CHAL & $8 / 10 / 10$ & $<\mathrm{DL}$ & 32.8 & 449.6 & 1.6 \\
\hline OLDSWT & $8 / 10 / 10$ & $<\mathrm{DL}$ & 29.5 & 399.8 & 1.7 \\
\hline CHAL (D) & $9 / 25 / 10$ & $<\mathrm{DL}$ & 36.0 & 430.0 & 0.8 \\
\hline CHAL & $9 / 25 / 10$ & $<\mathrm{DL}$ & 35.9 & 400.0 & 1.3 \\
\hline OLDSWT & $9 / 25 / 10$ & $<\mathrm{DL}$ & 30.6 & 402.5 & 1.6 \\
\hline SPELM & $9 / 25 / 10$ & $<\mathrm{DL}$ & 4.1 & 12.6 & 1.3 \\
\hline CHAL & $11 / 20 / 10$ & $<\mathrm{DL}$ & 33.4 & 441.1 & $<\mathrm{DL}$ \\
\hline OLDSWT & $11 / 20 / 10$ & $<\mathrm{DL}$ & 29.4 & 376.4 & $<\mathrm{DL}$ \\
\hline CESSPE & $11 / 21 / 10$ & $<\mathrm{DL}$ & 16.3 & 116.4 & $<\mathrm{DL}$ \\
\hline CREEK6115 & $11 / 21 / 10$ & $<\mathrm{DL}$ & 16.1 & 224.3 & $<\mathrm{DL}$ \\
\hline OLDSWT & $5 / 27 / 11$ & 1 & 27.6 & 386.0 & $<\mathrm{DL}$ \\
\hline CHAL & $5 / 27 / 11$ & 1 & 30.7 & 439.0 & $<\mathrm{DL}$ \\
\hline CREEK3740 & $5 / 27 / 11$ & $<\mathrm{DL}$ & 6.0 & 46.5 & 1.2 \\
\hline CREEK3890 & $5 / 28 / 11$ & $<\mathrm{DL}$ & 5.4 & 37.3 & 1.5 \\
\hline CREEK6115 & $5 / 28 / 11$ & $<\mathrm{DL}$ & 8.0 & 87.6 & 1.3 \\
\hline CHAL2.0M & $5 / 28 / 11$ & 1 & 19.0 & 383.0 & 0.7 \\
\hline CHAL2.0C & $5 / 28 / 11$ & 1 & 14.0 & 267.0 & 1.6 \\
\hline CREEK4010 & $5 / 29 / 11$ & $<\mathrm{DL}$ & 8.0 & 79.2 & 1.3 \\
\hline CREEK4120 & $5 / 29 / 11$ & $<\mathrm{DL}$ & 8.0 & 82.3 & 1.4 \\
\hline OLDSWT & $6 / 28 / 11$ & $<\mathrm{DL}$ & 28.7 & 395.1 & $<\mathrm{DL}$ \\
\hline CHAL & $6 / 28 / 11$ & $<\mathrm{DL}$ & 30.9 & 426.6 & $<\mathrm{DL}$ \\
\hline CHAL2.0C & $6 / 28 / 11$ & $<\mathrm{DL}$ & 20.1 & 417.9 & 0.4 \\
\hline CHAL2.0M & $6 / 28 / 11$ & $<\mathrm{DL}$ & 20.6 & 434.9 & 0.3 \\
\hline CESSPE & $6 / 28 / 11$ & $<\mathrm{DL}$ & 21.5 & 114.8 & $<\mathrm{DL}$ \\
\hline SPELM & $6 / 28 / 11$ & $<\mathrm{DL}$ & 3.0 & 20.3 & 2.16 \\
\hline OLDSWT & $8 / 1 / 11$ & $<\mathrm{DL}$ & 29.4 & 400.0 & 0.9 \\
\hline CHAL & $8 / 2 / 11$ & $<\mathrm{DL}$ & 32.1 & 432.1 & 1.1 \\
\hline CREEK3740 & $8 / 2 / 11$ & $<\mathrm{DL}$ & 10.5 & 109.2 & 1.8 \\
\hline CREEK3890 & $8 / 2 / 11$ & $<\mathrm{DL}$ & 12.9 & 139.7 & 1.9 \\
\hline CREEK4010 & $8 / 2 / 11$ & $<\mathrm{DL}$ & 15.2 & 180.1 & 1.5 \\
\hline CREEK4120 & $8 / 2 / 11$ & $<\mathrm{DL}$ & 15.3 & 191.5 & 1.5 \\
\hline CESSPE & $8 / 3 / 11$ & $<\mathrm{DL}$ & 20.5 & 114.8 & 5.3 \\
\hline CHAL2.0C & $8 / 3 / 11$ & $<\mathrm{DL}$ & 21.4 & 435.8 & 1.4 \\
\hline CHAL2.0M & $8 / 3 / 11$ & $<\mathrm{DL}$ & 22.5 & 447.6 & 1.0 \\
\hline CREEK6115 & $8 / 3 / 11$ & $<\mathrm{DL}$ & 15.3 & 198.1 & 1.6 \\
\hline CREEK6150 (D) & $8 / 3 / 11$ & $<\mathrm{DL}$ & 15.3 & 197.8 & 1.3 \\
\hline CREEK6150 & $8 / 3 / 11$ & $<\mathrm{DL}$ & 14.9 & 196.3 & 1.5 \\
\hline
\end{tabular}


Table 5B- Plate Measurements for May-June

\begin{tabular}{|c|c|c|c|c|c|c|c|c|c|c|c|c|}
\hline Plate & Site & $\begin{array}{l}\text { Weight Avg } \\
\text { Before (g) }\end{array}$ & $\begin{array}{l}\text { Weight Avg } \\
\text { After (g) }\end{array}$ & $\begin{array}{c}\text { Change } \\
\text { Weight (g) }\end{array}$ & $\begin{array}{l}\text { Time - Date } \\
\text { Installed }\end{array}$ & $\begin{array}{l}\text { Time - Date } \\
\text { Removed }\end{array}$ & $\begin{array}{c}\text { Time in } \\
\text { Water (hrs) }\end{array}$ & $\begin{array}{l}\mathrm{L} 1 \\
(\mathrm{~mm})\end{array}$ & $\begin{array}{l}\mathrm{L2} \\
(\mathrm{mm})\end{array}$ & $\begin{array}{l}\text { Thickness } \\
(\mathrm{mm})\end{array}$ & $\begin{array}{l}\text { Area } \\
\left(\mathrm{cm}^{2}\right)\end{array}$ & $\begin{array}{c}\Delta \text { Weight / Area } \\
\left(\mathrm{mg} / \mathrm{cm}^{2}\right)\end{array}$ \\
\hline 1 & CREEK3890 & 51.634 & 51.638 & 0.004 & $11: 00$ (5-27-2011) & $14: 00(8-1-2011)$ & 1587 & 4.90 & 5.00 & 1 & 69.72 & 0.05 \\
\hline 2 & CREEK3890 & 58.857 & 58.920 & 0.064 & $11: 00(5-27-2011)$ & $14: 00(6-28-2011)$ & 771 & 4.90 & 4.90 & 1 & 68.54 & 0.93 \\
\hline 3 & CREEK3890 & 61.833 & 61.854 & 0.021 & $11: 00(5-27-2011)$ & $14: 00(6-28-2011)$ & 771 & 5.05 & 4.90 & 1 & 70.31 & 0.30 \\
\hline 4 & CHAL & 59.636 & 59.656 & 0.020 & $12: 30(5-27-2011)$ & $14: 00(6-28-2011)$ & 769.5 & 4.90 & 4.80 & 1 & 67.36 & 0.30 \\
\hline 5 & CHAL & 56.346 & 56.289 & -0.057 & $12: 30(5-27-2011)$ & $14: 00(6-28-2011)$ & 769.5 & 4.90 & 4.90 & 1 & 68.54 & -0.83 \\
\hline 6 & CHAL & 55.494 & 55.422 & -0.071 & $12: 30(5-27-2011)$ & $13: 30(8-2-2011)$ & 1609 & 4.90 & 4.90 & 1 & 68.54 & -1.04 \\
\hline 7 & CREEK3740 & 59.413 & 60.216 & 0.803 & $13: 30(5-26-2011)$ & $10: 00(8-1-2011)$ & 1604.5 & 4.90 & 4.95 & 1 & 69.13 & 11.62 \\
\hline 8 & CREEK3740 & 56.195 & 56.308 & 0.113 & $13: 30(5-26-2011)$ & $14: 00(6-28-2011)$ & 792.5 & 4.85 & 4.90 & 1 & 67.95 & 1.66 \\
\hline 9 & CREEK3740 & 58.866 & 58.969 & 0.103 & $13: 30(5-26-2011)$ & $14: 00(6-28-2011)$ & 792.5 & 5.00 & 4.95 & 1 & 70.32 & 1.47 \\
\hline 11 & OLDSWT & 56.523 & 56.379 & -0.143 & $16: 30(5-27-2011)$ & $15: 00(8-4-2011)$ & 1654.5 & 4.90 & 4.85 & 1 & 67.95 & -2.11 \\
\hline 12 & OLDSWT & 56.931 & 56.865 & -0.066 & $16: 30(5-27-2011)$ & $10: 00(6-28-2011)$ & 761.5 & 4.90 & 5.00 & 1 & 69.72 & -0.95 \\
\hline 16 & CREEK6115 & 50.406 & 50.557 & 0.151 & $17: 00(5-28-2011)$ & $16: 00(6-29-2011)$ & 743 & 4.95 & 4.90 & 1 & 69.13 & 2.18 \\
\hline 17 & CREEK6115 & 58.433 & 58.511 & 0.078 & $17: 00(5-28-2011)$ & $16: 00(6-29-2011)$ & 743 & 4.90 & 4.90 & 1 & 68.54 & 1.13 \\
\hline 18 & CREEK6115 & 55.727 & 55.962 & 0.236 & $17: 00(5-28-2011)$ & $11: 30(8-3-2011)$ & 1602.5 & 4.95 & 5.00 & 1 & 70.32 & 3.35 \\
\hline 19 & CREEK4120 & 57.757 & 57.788 & 0.031 & $9: 30(5-29-2011)$ & $15: 00(8-2-2011)$ & 1565.5 & 5.00 & 4.90 & 1 & 69.72 & 0.45 \\
\hline 20 & CREEK4120 & 53.017 & 53.210 & 0.194 & $9: 30(5-29-2011)$ & $16: 00(6-29-2011)$ & 726.5 & 4.90 & 4.85 & 1 & 67.95 & 2.85 \\
\hline 21 & CREEK4120 & 57.365 & 57.473 & 0.108 & $9: 30(5-29-2011)$ & $16: 00(6-29-2011)$ & 726.5 & 5.05 & 4.85 & 1 & 69.70 & 1.55 \\
\hline 22 & CREEK4010 & 59.349 & 59.493 & 0.144 & $12: 00(5-29-2011)$ & $17: 00(8-2-2011)$ & 1565 & 4.85 & 4.95 & 1 & 68.53 & 2.10 \\
\hline 23 & CREEK4010 & 52.514 & 52.694 & 0.180 & $12: 00(5-29-2011)$ & $16: 00(8-29-2011)$ & 724 & 4.85 & 4.95 & 1 & 68.53 & 2.63 \\
\hline 26 & CREEK4010 & 60.067 & 60.136 & 0.068 & $12: 00(5-29-2011)$ & $16: 00(8-29-2011)$ & 724 & 5.00 & 4.90 & 1 & 69.72 & 0.98 \\
\hline
\end{tabular}


Table 6B - Plate Measurements for August - September

\begin{tabular}{|c|c|c|c|c|c|c|c|c|c|c|c|c|}
\hline Plate & Site & $\begin{array}{l}\text { Weight Avg } \\
\text { Before (g) }\end{array}$ & $\begin{array}{l}\text { Weight Avg } \\
\text { After (g) }\end{array}$ & $\begin{array}{l}\text { Change } \\
\text { Weight (g) }\end{array}$ & $\begin{array}{l}\text { Time - Date } \\
\text { Installed }\end{array}$ & $\begin{array}{l}\text { Time - Date } \\
\text { Removed }\end{array}$ & $\begin{array}{c}\text { Time in } \\
\text { Water (hrs) }\end{array}$ & $\begin{array}{c}\mathrm{L} 1 \\
(\mathrm{~mm})\end{array}$ & $\begin{array}{c}\mathrm{L} 2 \\
(\mathrm{~mm})\end{array}$ & $\begin{array}{l}\text { Thickness } \\
(\mathrm{mm})\end{array}$ & $\begin{array}{l}\text { Area } \\
\left(\mathrm{cm}^{2}\right)\end{array}$ & $\begin{array}{c}\Delta \text { Weight / Area } \\
\left(\mathrm{mg} / \mathrm{cm}^{2}\right)\end{array}$ \\
\hline A47 & CREEK6115 & 54.391 & 55.049 & 0.658 & $11: 30(8-3-2011)$ & $14: 00(9-4-2011)$ & 770.5 & 48.61 & 50.53 & 10.01 & 66.73 & 9.86 \\
\hline A15 & CREEK6115 & 54.605 & 55.365 & 0.760 & $11: 30(8-3-2011)$ & $14: 00(9-4-2011)$ & 770.5 & 49.37 & 48.69 & 10.00 & 64.92 & 11.70 \\
\hline A40 & CREEK6115 & 54.904 & 55.690 & 0.786 & $11: 30(8-3-2011)$ & $14: 00(9-4-2011)$ & 770.5 & 49.08 & 49.24 & 10.02 & 65.44 & 12.01 \\
\hline A10 & CREEK6115 & 55.015 & 55.719 & 0.704 & $11: 30(8-3-2011)$ & $14: 00(9-4-2011)$ & 770.5 & 49.8 & 48.89 & 9.67 & 65.04 & 10.82 \\
\hline A21 & CREEK6115 & 55.067 & 55.782 & 0.715 & $11: 30(8-3-2011)$ & $14: 00(9-4-2011)$ & 770.5 & 49.81 & 50.04 & 9.36 & 66.08 & 10.82 \\
\hline A38 & CREEK6115 & 55.374 & 56.183 & 0.809 & $11: 30(8-3-2011)$ & $14: 00(9-4-2011)$ & 770.5 & 50.04 & 50.08 & 10.05 & 67.61 & 11.97 \\
\hline A49 & $\mathrm{CHAL}$ & 56.685 & 56.681 & -0.004 & $13: 30(8-2-2011)$ & $13: 00(9-4-2011)$ & 743.5 & 48.77 & 49.52 & 10.01 & 65.50 & -0.06 \\
\hline A11 & CHAL & 57.047 & 57.061 & 0.014 & $13: 30(8-2-2011)$ & $13: 00(9-4-2011)$ & 743.5 & 48.8 & 48.9 & 9.94 & 64.55 & 0.22 \\
\hline A32 & CHAL & 57.049 & 57.035 & -0.014 & $13: 30(8-2-2011)$ & $13: 00(9-4-2011)$ & 743.5 & 49 & 49.22 & 9.89 & 65.10 & -0.22 \\
\hline A19 & CHAL & 57.051 & 57.086 & 0.036 & $13: 30(8-2-2011)$ & $13: 00(9-4-2011)$ & 743.5 & 48.04 & 49.62 & 9.99 & 64.88 & 0.55 \\
\hline A26 & CHAL & 57.189 & 57.166 & -0.023 & $13: 30(8-2-2011)$ & $13: 00(9-4-2011)$ & 743.5 & 49.12 & 50.39 & 9.95 & 66.94 & -0.35 \\
\hline $\mathrm{A} 1$ & CHAL & 57.217 & 57.241 & 0.024 & $13: 30(8-2-2011)$ & $13: 00(9-4-2011)$ & 743.5 & 47.9 & 48.76 & 10.09 & 63.75 & 0.38 \\
\hline A18 & CREEK4120 & 57.488 & 57.568 & 0.080 & $15: 00(8-2-2011)$ & $11: 00(9-4-2011)$ & 740.0 & 50.17 & 48.05 & 9.95 & 64.72 & 1.24 \\
\hline A12 & CREEK4120 & 57.531 & 57.637 & 0.105 & $15: 00(8-2-2011)$ & $11: 00(9-4-2011)$ & 740.0 & 49.96 & 48.67 & 9.98 & 65.44 & 1.61 \\
\hline A42 & CREEK4120 & 57.653 & 57.684 & 0.031 & $15: 00(8-2-2011)$ & $11: 00$ (9-4-2011) & 740.0 & 50.27 & 48.29 & 9.82 & 64.93 & 0.47 \\
\hline A41 & CREEK4120 & 57.661 & 57.674 & 0.013 & $15: 00(8-2-2011)$ & $11: 00(9-4-2011)$ & 740.0 & 49.4 & 49.13 & 9.85 & 65.30 & 0.19 \\
\hline A43 & CREEK4120 & 57.774 & 57.819 & 0.046 & $15: 00(8-2-2011)$ & $11: 00(9-4-2011)$ & 740.0 & 49.94 & 49.16 & 9.98 & 66.10 & 0.69 \\
\hline A7 & CREEK4120 & 58.026 & 58.106 & 0.080 & $15: 00(8-2-2011)$ & $11: 00(9-4-2011)$ & 740.0 & 49.05 & 49.86 & 10.15 & 66.50 & 1.21 \\
\hline
\end{tabular}


Table 6B - Plate Measurements for August - September Cont.

\begin{tabular}{|c|c|c|c|c|c|c|c|c|c|c|c|c|}
\hline Plate & Site & $\begin{array}{l}\text { Weight Avg } \\
\text { Before (g) } \\
\end{array}$ & $\begin{array}{l}\text { Weight Avg } \\
\text { After (g) } \\
\end{array}$ & $\begin{array}{c}\text { Change } \\
\text { Weight (g) } \\
\end{array}$ & $\begin{array}{c}\text { Time - Date } \\
\text { Installed } \\
\end{array}$ & $\begin{array}{c}\text { Time - Date } \\
\text { Removed } \\
\end{array}$ & $\begin{array}{c}\text { Time in } \\
\text { Water (hrs) } \\
\end{array}$ & $\begin{array}{c}\mathrm{L} 1 \\
(\mathrm{~mm}) \\
\end{array}$ & $\begin{array}{c}\mathrm{L} 2 \\
(\mathrm{~mm}) \\
\end{array}$ & $\begin{array}{l}\text { Thickness } \\
(\mathrm{mm})\end{array}$ & $\begin{array}{l}\text { Area } \\
\left(\mathrm{cm}^{2}\right) \\
\end{array}$ & $\begin{array}{c}\Delta \text { Weight / Area } \\
\left(\mathrm{mg} / \mathrm{cm}^{2}\right) \\
\end{array}$ \\
\hline A23 & CREEK3890 & 58.267 & 58.302 & 0.035 & $11: 30(8-2-2011)$ & $12: 30(9-4-2011)$ & 745.0 & 49.7 & 49.01 & 9.98 & 65.73 & 0.53 \\
\hline A16 & CREEK3890 & 58.300 & 58.335 & 0.035 & $11: 30(8-2-2011)$ & $12: 30(9-4-2011)$ & 745.0 & 50.0 & 48.99 & 9.94 & 65.94 & 0.53 \\
\hline $\mathrm{A} 2$ & CREEK3890 & 58.473 & 58.506 & 0.032 & $11: 30(8-2-2011)$ & $12: 30(9-4-2011)$ & 745.0 & 49.7 & 48.82 & 9.96 & 65.43 & 0.49 \\
\hline A6 & CREEK3890 & 58.573 & 58.574 & 0.001 & $11: 30(8-2-2011)$ & $12: 30(9-4-2011)$ & 745.0 & 49.1 & 49.74 & 9.96 & 66.11 & 0.01 \\
\hline A20 & CREEK3890 & 58.578 & 58.612 & 0.034 & $11: 30(8-2-2011)$ & $12: 30(9-4-2011)$ & 745.0 & 50.3 & 50.13 & 10.00 & 67.85 & 0.50 \\
\hline A25 & CREEK3890 & 59.019 & 59.048 & 0.028 & $11: 30(8-2-2011)$ & $12: 30(9-4-2011)$ & 745.0 & 50.0 & 49.37 & 9.94 & 66.42 & 0.43 \\
\hline$A 31$ & CREEK4010 & 59.045 & 59.101 & 0.056 & $17: 00(8-2-2011)$ & $11: 30(9-4-2011)$ & 738.5 & 49.4 & 50.05 & 9.96 & 66.85 & 0.84 \\
\hline A29 & CREEK4010 & 59.554 & 59.613 & 0.059 & $17: 00(8-2-2011)$ & $11: 30(9-4-2011)$ & 738.5 & 50.1 & 49.62 & 9.95 & 66.91 & 0.89 \\
\hline A9 & CREEK4010 & 59.567 & 59.621 & 0.054 & $17: 00(8-2-2011)$ & $11: 30(9-4-2011)$ & 738.5 & 49.4 & 50.32 & 9.95 & 67.13 & 0.81 \\
\hline A8 & CREEK4010 & 59.641 & 59.712 & 0.071 & $17: 00(8-2-2011)$ & $11: 30(9-4-2011)$ & 738.5 & 50.0 & 49.36 & 10.00 & 66.52 & 1.07 \\
\hline A4 & CREEK4010 & 59.693 & 59.739 & 0.046 & $17: 00(8-2-2011)$ & $11: 30(9-4-2011)$ & 738.5 & 50.1 & 49.96 & 9.95 & 67.33 & 0.68 \\
\hline A28 & CREEK4010 & 59.693 & 59.772 & 0.079 & $17: 00(8-2-2011)$ & $11: 30(9-4-2011)$ & 738.5 & 49.5 & 50.36 & 9.98 & 67.36 & 1.17 \\
\hline A24 & CREEK3740 & 59.974 & 61.563 & 1.589 & $10: 00(8-1-2011)$ & $9: 30(9-4-2011)$ & 743.5 & 50.2 & 50.02 & 9.92 & 67.46 & 23.55 \\
\hline A30 & CREEK3740 & 60.043 & 61.444 & 1.401 & $10: 00(8-1-2011)$ & $9: 30(9-4-2011)$ & 743.5 & 49.2 & 49.56 & 10.09 & 66.15 & 21.18 \\
\hline A34 & CREEK3740 & 60.544 & 61.808 & 1.264 & $10: 00(8-1-2011)$ & $9: 30(9-4-2011)$ & 743.5 & 50.1 & 50.42 & 9.97 & 68.08 & 18.57 \\
\hline A13 & CREEK3740 & 60.599 & 62.089 & 1.490 & $10: 00(8-1-2011)$ & $9: 30(9-4-2011)$ & 743.5 & 50.1 & 49.81 & 10.04 & 67.29 & 22.15 \\
\hline A3 & CREEK3740 & 61.100 & 62.616 & 1.516 & $10: 00(8-1-2011)$ & $9: 30(9-4-2011)$ & 743.5 & 50.8 & 50.26 & 9.96 & 68.50 & 22.14 \\
\hline A14 & CREEK3740 & 61.703 & 63.135 & 1.432 & $10: 00(8-1-2011)$ & 9:30 (9-4-2011) & 743.5 & 51.2 & 48.94 & 10.19 & 67.43 & 21.23 \\
\hline
\end{tabular}


Table 7B- Instrument accuracy and error

\begin{tabular}{|c|c|c|c|c|}
\hline Parameter & Units & Instrument & Instrument Accuracy & Sources of Error \\
\hline pH & & $\begin{array}{l}\text { Hanna }^{\circledR} \text { HI-9025 } \\
\text { Hanna }^{\circledR} \text { HI-1230 Probe } \\
\text { YSI }^{\circledR} 556-\mathrm{MP}\end{array}$ & $\begin{array}{l} \pm 0.02 \\
\pm 0.01\end{array}$ & $\begin{array}{l}\text { Calibration } \\
\text { Degassing }\end{array}$ \\
\hline Temperature & ${ }^{\circ} \mathrm{Ce}$ ssius & $\begin{array}{l}\text { Hanna }^{\circledR} \mathrm{HI}-9025 \\
\text { Hanna }^{\circledR} \text { HI-7669 Probe } \\
\text { YSI }^{\circledR} 556-\mathrm{MP}\end{array}$ & $\begin{array}{l} \pm 0.5^{\circ} \mathrm{C} \\
\pm 0.15^{\circ} \mathrm{C}\end{array}$ & Probe Location \\
\hline $\mathrm{CO} 2$ & $\mathrm{~g} / \mathrm{L}$ & CarboQC$^{\circledR}$ & $\pm 0.01 \mathrm{mg} / \mathrm{L}$ & $\begin{array}{l}\text { Degassing } \\
\text { Bubbles in the } \\
\text { Chamber }\end{array}$ \\
\hline Conductivity & $\mu \mathrm{S} / \mathrm{cm}$ & YSI ${ }^{\circledR} 556-M P$ & $\pm 0.001 \mathrm{~ms} / \mathrm{cm}$ & Calibration \\
\hline $\begin{array}{l}\text { Dissolved } \\
\text { Oxygen }\end{array}$ & $\%$ & YSI ${ }^{\circledast} 556-\mathrm{MP}$ & $\begin{array}{l}0-200 \% \text { air } \\
\text { saturation, } \pm 2 \% \text { of the } \\
\text { reading or } \pm 2 \% \text { air } \\
\text { saturation reading, } \\
\text { whichever is greater }\end{array}$ & Calibration \\
\hline Alkalinity & $\mathrm{mg} / \mathrm{L} \mathrm{HCO}_{3}$ & $\begin{array}{l}\text { Hach }^{\circledast} \text { Digital Titrator } \\
\text { Model } 16900\end{array}$ & $\pm 1 \%$ & $\begin{array}{l}\text { Degassing } \\
\text { Calibration }(\mathrm{pH}) \\
\text { Titration Error }\end{array}$ \\
\hline Discharge & $\mathrm{m}^{3} / \mathrm{s}$ & $\begin{array}{l}\text { Swoffer }{ }^{\circledR} \text { Current } \\
\text { Velocity Meter } 3000\end{array}$ & $\pm 1 \%$ & $\begin{array}{l}\text { Calibration } \\
\text { Channel Geometry } \\
\text { Obstructions }\end{array}$ \\
\hline Location & $\begin{array}{l}\text { NAD-83 } \\
\text { UTM }\end{array}$ & $\begin{array}{l}\text { Garmin }^{\circledR} 12 \mathrm{XL} \\
\text { Google Earth } \\
\text { Goo }^{\circ}\end{array}$ & Varies & $\begin{array}{l}\text { Satellite Reception } \\
\text { Resolution }\end{array}$ \\
\hline
\end{tabular}




\begin{tabular}{lcccr} 
Table 8B $-\mathrm{Fe}^{2+}$ data & \multicolumn{3}{c}{ ( } \\
\hline \hline Sample ID & Date & $\begin{array}{c}\text { (n) } \\
\text { samples }\end{array}$ & $\begin{array}{c}\text { Average Fe } \\
\text { (mg/L) }\end{array}$ & $\begin{array}{c}\text { RSD } \\
\text { (\%) }\end{array}$ \\
\hline \hline OLDSWT & $5 / 27 / 11$ & 5 & 0.087 & 7.08 \\
CHAL & $5 / 27 / 11$ & 5 & 0.479 & 6.97 \\
CREEK3740 & $5 / 26 / 11$ & 5 & 0.157 & 14.70 \\
CREEK3890 & $5 / 27 / 11$ & 4 & 0.975 & 8.66 \\
CREEK6115 & $5 / 28 / 11$ & 4 & 0.125 & 12.70 \\
CHAL2.0M & $5 / 28 / 11$ & 4 & 0.530 & 8.31 \\
CHAL2.0C & $5 / 28 / 11$ & 5 & 0.319 & 13.76 \\
CREEK4010 & $5 / 29 / 11$ & 4 & $<\mathrm{DL}$ & \\
CREEK4120 & $5 / 29 / 11$ & 4 & $<\mathrm{DL}$ & \\
SPELM & $6 / 28 / 11$ & 5 & $<\mathrm{DL}$ & \\
OLDSWT & $6 / 28 / 11$ & 3 & $<\mathrm{DL}$ & \\
CHAL & $6 / 28 / 11$ & 6 & 0.171 & 5.33 \\
CHAL2.0C & $6 / 28 / 11$ & 6 & 0.728 & 29.75 \\
CHAL2.0M & $6 / 28 / 11$ & 6 & 0.392 & 77.85 \\
CESSPE & $6 / 28 / 11$ & 3 & $<\mathrm{DL}$ & \\
OLDSWT & $8 / 1 / 11$ & 4 & 0.010 & 94.99 \\
CHAL & $8 / 2 / 11$ & 4 & 0.152 & 4.00 \\
CREEK3740 & $8 / 2 / 11$ & 4 & 0.012 & 32.05 \\
CREEK3890 & $8 / 2 / 11$ & 6 & 0.042 & 24.82 \\
CREEK4010 & $8 / 2 / 11$ & 4 & 0.039 & 72.62 \\
CREEK4120 & $8 / 2 / 11$ & 4 & 0.017 & 40.87 \\
CHAL2.0C & $8 / 3 / 11$ & 4 & 0.213 & 14.77 \\
CHAL2.0M & $8 / 3 / 11$ & 4 & 0.214 & 11.26 \\
CESSPE & $8 / 3 / 11$ & 4 & 1.342 & 73.61 \\
CREEK6115 & $8 / 3 / 11$ & 4 & $<\mathrm{DL}$ & \\
CREEK6150 & $8 / 3 / 11$ & 4 & $<\mathrm{DL}$ & \\
\hline \hline & & & & \\
\hline
\end{tabular}


Table 9B - Hydrogen sulfide data reported as $\mathrm{S}^{-2}$

\begin{tabular}{|c|c|c|c|c|}
\hline Site & Date & $\begin{array}{c}\text { Samples } \\
\text { (n) }\end{array}$ & $\begin{array}{c}\text { Average } \mathrm{S}^{-2} \\
\left(\mu \mathrm{g} \mathrm{L}^{-1}\right) \\
\end{array}$ & RSD (\%) \\
\hline OLDSWT & $5 / 27 / 11$ & 3 & 6 & 80 \\
\hline CHAL & $5 / 27 / 11$ & 4 & $<D L$ & \\
\hline CREEK3740 & $5 / 26 / 11$ & 3 & 41 & 7.1 \\
\hline CREEK3890 & $5 / 27 / 11$ & 3 & 20 & 10 \\
\hline CREEK6115 & $5 / 28 / 11$ & 3 & 14 & 15 \\
\hline CHAL2.0M & $5 / 28 / 11$ & 4 & $<\mathrm{DL}$ & \\
\hline CHAL2.0C & $5 / 28 / 11$ & 3 & $<\mathrm{DL}$ & \\
\hline CREEK4010 & $5 / 29 / 11$ & 4 & 13 & 26 \\
\hline CREEK4120 & $5 / 29 / 11$ & 4 & $<D L$ & \\
\hline SPELM & $6 / 28 / 11$ & 2 & $<\mathrm{DL}$ & \\
\hline OLDSWT & $6 / 28 / 11$ & 3 & $<\mathrm{DL}$ & \\
\hline $\mathrm{CHAL}$ & $6 / 28 / 11$ & 2 & 68 & 5.2 \\
\hline CHAL2.0C & $6 / 28 / 11$ & 2 & $<\mathrm{DL}$ & \\
\hline CHAL2.0M & $6 / 28 / 11$ & 2 & 17 & 13 \\
\hline CESSPE & $6 / 28 / 11$ & 4 & 1,404 & 7.0 \\
\hline OLDSWT & $8 / 1 / 11$ & 3 & 5 & 29 \\
\hline $\mathrm{CHAL}$ & $8 / 2 / 11$ & 2 & $<\mathrm{DL}$ & \\
\hline CREEK3740 & $8 / 2 / 11$ & 3 & 9 & 6.7 \\
\hline CREEK3890 & $8 / 2 / 11$ & 3 & 6 & 27 \\
\hline CREEK4010 & $8 / 2 / 11$ & 3 & $<D L$ & \\
\hline CREEK4120 & $8 / 2 / 11$ & 3 & $<\mathrm{DL}$ & \\
\hline CHAL2.0C & $8 / 3 / 11$ & 3 & $<D L$ & \\
\hline CHAL2.0M & $8 / 3 / 11$ & 4 & $<\mathrm{DL}$ & \\
\hline CESSPE & $8 / 3 / 11$ & 9 & 4,263 & 5.7 \\
\hline CREEK6115 & $8 / 3 / 11$ & 3 & $<\mathrm{DL}$ & \\
\hline CREEK6150 & $8 / 3 / 11$ & 3 & $<\mathrm{DL}$ & \\
\hline
\end{tabular}


Table 10B - Filter blank data and detection limits

\begin{tabular}{|c|c|c|c|c|c|c|c|c|c|c|c|c|c|c|c|c|c|}
\hline $\begin{array}{l}\text { Sample } \\
\text { ID }\end{array}$ & Date & $\begin{array}{c}F \\
(\mathrm{mg} / \mathrm{L}) \\
\end{array}$ & $\begin{array}{c}\mathrm{Cl} \\
(\mathrm{mg} / \mathrm{L})\end{array}$ & $\begin{array}{c}\mathrm{SO}_{4} \\
(\mathrm{mg} / \mathrm{L}) \\
\end{array}$ & $\begin{array}{c}\mathrm{NO}_{3} \\
(\mathrm{mg} / \mathrm{L}) \\
\end{array}$ & $\begin{array}{c}\mathrm{Ba} \\
\text { (ug/L) }\end{array}$ & $\begin{array}{c}\mathrm{Ca} \\
(\mathrm{mg} / \mathrm{L})\end{array}$ & $\begin{array}{c}\mathrm{Fe} \\
(\mathrm{ug} / \mathrm{L}) \\
\end{array}$ & $\begin{array}{c}\mathrm{K} \\
\text { (ug/L) } \\
\end{array}$ & $\begin{array}{c}\mathrm{Li} \\
\text { (ug/L) }\end{array}$ & $\begin{array}{c}\mathrm{Mg} \\
\text { (ug/L) }\end{array}$ & $\begin{array}{c}\mathrm{Mn} \\
\text { (ug/L) }\end{array}$ & $\begin{array}{c}\mathrm{Na} \\
\text { (ug/L) }\end{array}$ & $\begin{array}{c}\mathrm{S} \\
(\mathrm{mg} / \mathrm{L})\end{array}$ & $\begin{array}{c}\mathrm{Si} \\
\text { (ug/L) } \\
\end{array}$ & $\begin{array}{c}\mathrm{Sr} \\
\text { (ug/L) }\end{array}$ & $\begin{array}{c}\mathrm{Zn} \\
\text { (ug/L) }\end{array}$ \\
\hline $\begin{array}{l}\text { MDL - } \\
40311\end{array}$ & $5 / 13 / 10$ & 1 & 1 & 1 & 1 & 0.1 & 0.01 & 1 & 15 & 3 & 1 & 1 & 7 & 0.01 & 10 & 5 & 1 \\
\hline $\begin{array}{l}\text { WVU- } \\
\text { FB40402 }\end{array}$ & $8 / 12 / 10$ & $<\mathrm{DL}$ & $<\mathrm{DL}$ & $<\mathrm{DL}$ & $<\mathrm{DL}$ & $<\mathrm{DL}$ & $<\mathrm{DL}$ & $<\mathrm{DL}$ & 18 & $<\mathrm{DL}$ & $<\mathrm{DL}$ & $<\mathrm{DL}$ & 86 & $<\mathrm{DL}$ & $<\mathrm{DL}$ & $<\mathrm{DL}$ & $<\mathrm{DL}$ \\
\hline $\begin{array}{l}\text { WVU- } \\
\text { FB40515 }\end{array}$ & $8 / 25 / 10$ & $<\mathrm{DL}$ & $<\mathrm{DL}$ & $<\mathrm{DL}$ & $<\mathrm{DL}$ & 6 & $<\mathrm{DL}$ & $<\mathrm{DL}$ & 17 & $<\mathrm{DL}$ & $<\mathrm{DL}$ & $<\mathrm{DL}$ & 105 & $<\mathrm{DL}$ & $<\mathrm{DL}$ & $<\mathrm{DL}$ & 7 \\
\hline $\begin{array}{l}\text { WVU- } \\
\text { FB40453 }\end{array}$ & $10 / 2 / 10$ & $<\mathrm{DL}$ & 1.6 & $<\mathrm{DL}$ & 1.4 & 4 & 0.1 & 2 & $<\mathrm{DL}$ & $<\mathrm{DL}$ & $<\mathrm{DL}$ & $<\mathrm{DL}$ & 11 & $<\mathrm{DL}$ & $<\mathrm{DL}$ & $<\mathrm{DL}$ & 4 \\
\hline $\begin{array}{l}\text { WVU- } \\
\text { FB40692 }\end{array}$ & $5 / 29 / 11$ & $<\mathrm{DL}$ & $<\mathrm{DL}$ & $<\mathrm{DL}$ & $<\mathrm{DL}$ & $<\mathrm{DL}$ & $<\mathrm{DL}$ & $<\mathrm{DL}$ & 16 & $<\mathrm{DL}$ & $<\mathrm{DL}$ & $<\mathrm{DL}$ & 171 & $<\mathrm{DL}$ & 52 & $<\mathrm{DL}$ & $<\mathrm{DL}$ \\
\hline
\end{tabular}


Appendix C: Hydrogen Sulfide - "Fixing" Method 
The methylene blue method is used as the means to determine $\mathrm{H}_{2} \mathrm{~S}$ concentrations colorimetrically. In the method, Dimethyl-4-phenylenediamine and $\mathrm{FeCl}$ reduce hydrogen sulfide; the reduction forms methylene blue (Cline, 1969; Lindsay and Baedecker, 1988); see Equation 1 below. The intensity of color depends on both the concentration of hydrogen sulfide and the amount of reagent added (Lindsay and Baedecker, 1988). Hydrogen sulfide is the limiting component as additional $\mathrm{FeCl}$ and dimethyl-4-phenylenediamine will not change the color of the solution further after all hydrogen sulfide has reacted.

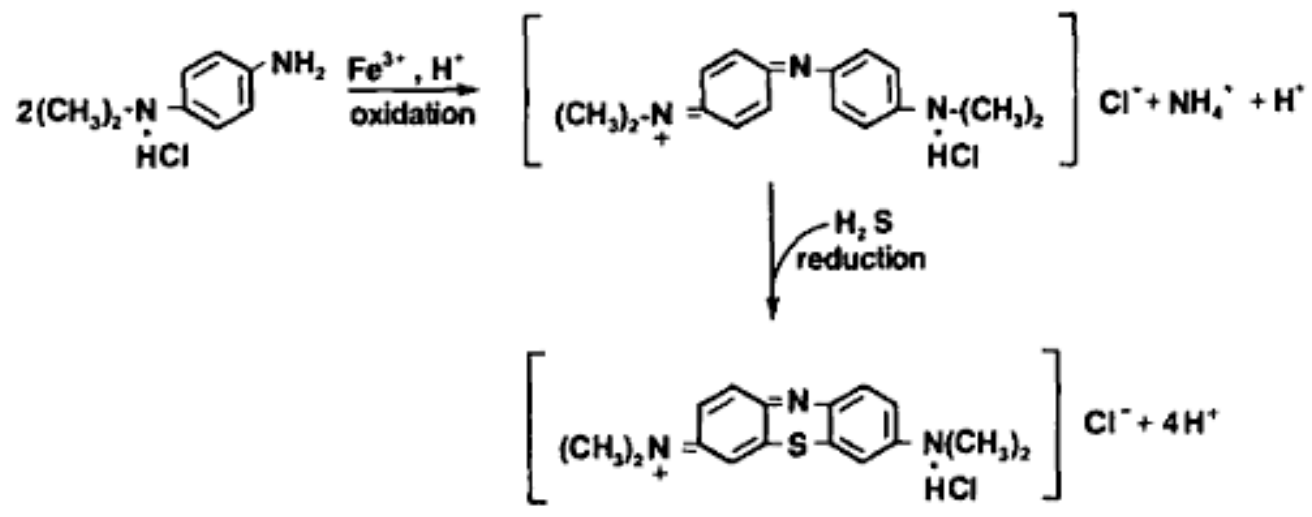

Equation 1 - Reaction of $\mathrm{FeCl}$ and Dimethyl-4-phenylenediamine with $\mathrm{H}_{2} \mathrm{~S}$ to form methylene blue. Modified from (Lindsay and Baedecker, 1988)

To determine if the reagents chemically stabilize hydrogen sulfide for an extended period of time (2-3 days), an experiment was designed that used both time delayed analysis and concentrations well above the measurement limit of most instruments, including the Hach $\subset$ DR2800 utilized herein. The procedure used propriety Hach @ reagents, Sulfide 1 Reagent and Sulfide 2 Reagent which are $\mathrm{FeCl}$ and Dimethyl-4-phenylenediamine solutions, respectively, to create methylene blue as they were originally designed to according to Hach (c) procedure 8130 for the DR2800. The reagents are used in the same quantity, $0.5 \mathrm{~mL}$ per $10 \mathrm{~mL}$ of sample, but applied before dilution in the original standard. A dilution scheme was designed to allow use with the DR-2800 (Table 1) as described by the Hach 8130 method. However, the dilution in the field as prescribed by the method introduces error and the instrument is difficult to carry along.

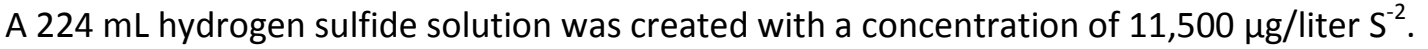
Sodium sulfide nonahydrate $\left(\mathrm{Na}_{2} \mathrm{~S} \cdot 9 \mathrm{H}_{2} \mathrm{O}\right)$ was added to $\mathrm{DI}$ and followed by the addition of $13 \mathrm{~mL}$ of Hach ${ }^{\circledR}$ Sulfide Reagents 1 \& 2; an additional $0.5 \mathrm{~mL}$ was added to account for the change in 
volume that is discussed in results section. The salt must be dissolved before adding reagents to minimize degassing. The volume was inverted several times to ensure complete mixing of reagents. Parafilm ${ }^{\circledR}$ was used to maintain an air-tight seal after addition of reagents.

\section{Results}

The first solution set was measured within 45 minutes of stock creation (Table 2).

Measurements for solution sets 2 and 3 were completed approximately 24 and 48 hours later respectively. Comparisons of the sample sets for each given day illustrate the stability of the solution over a range of time periods (Graph 1,2,3).

Minor variability in the concentrations is a function of human error during dilution and possibly due to the spectrophotometer zero point changing with each measurement.

Table 1

\begin{tabular}{|c|c|c|c|c|c|}
\hline Solution & $57.5 \mu \mathrm{g} \mathrm{S}^{-2}$ & $230 \mu \mathrm{g} \mathrm{S}^{-2}$ & $345 \mu \mathrm{g} \mathrm{S}^{-2}$ & $575 \mu \mathrm{g} \mathrm{S}^{-2}$ & $805 \mu g^{-2}$ \\
\hline$\mu$ L Sample & 75 & 300 & 450 & 750 & 1050 \\
\hline$\mu \mathrm{L} D \mathrm{I}$ & 14925 & 14700 & 14550 & 14250 & 13950 \\
\hline
\end{tabular}

The non-standard dilutions are the consequence of a decision to not add $26 \mathrm{~mL}$ of DI to the sample volume in order to minimize $\mathrm{H}_{2} \mathrm{~S}$ exsolution after the salt was added.

Table 2

\begin{tabular}{|l|r|r|r|r|r|}
\hline Solution & $\mathbf{5 7 . 5} \boldsymbol{\mu g} / \mathbf{L ~ S}^{-\mathbf{2}}$ & $\mathbf{2 3 0} \boldsymbol{\mu g} / \mathbf{L ~ S}^{-2}$ & $\mathbf{3 4 5} \boldsymbol{\mu g} / \mathbf{L ~ S}^{-2}$ & $\mathbf{5 7 5} \boldsymbol{\mu g} / \mathbf{L ~ S}^{-2}$ & $\mathbf{8 0 5} \boldsymbol{\mu g} / \mathbf{L ~ S}^{-2}$ \\
\hline (Day 1) Solution Set 1 & 59 & 270 & 396 & 658 & 882 \\
\hline (Day 1) Solution Set 2 & 61 & 262 & 391 & 656 & 892 \\
\hline (Day 1) Solution Set 3 & 63 & 266 & 393 & 652 & 895 \\
\hline (Day 2) Solution Set 1 & 57 & 253 & 359 & 650 & 871 \\
\hline (Day 2) Solution Set 2 & 58 & 259 & 357 & 649 & 867 \\
\hline (Day 2) Solution Set 3 & 38 & 259 & 386 & 601 & 811 \\
\hline (Day 3) Solution Set 1 & 55 & 261 & 387 & 634 & 860 \\
\hline (Day 3) Solution Set 2 & 54 & 253 & 375 & 642 & 862 \\
\hline (Day 3) Solution Set 3 & 29 & 243 & 388 & 636 & 811 \\
\hline
\end{tabular}




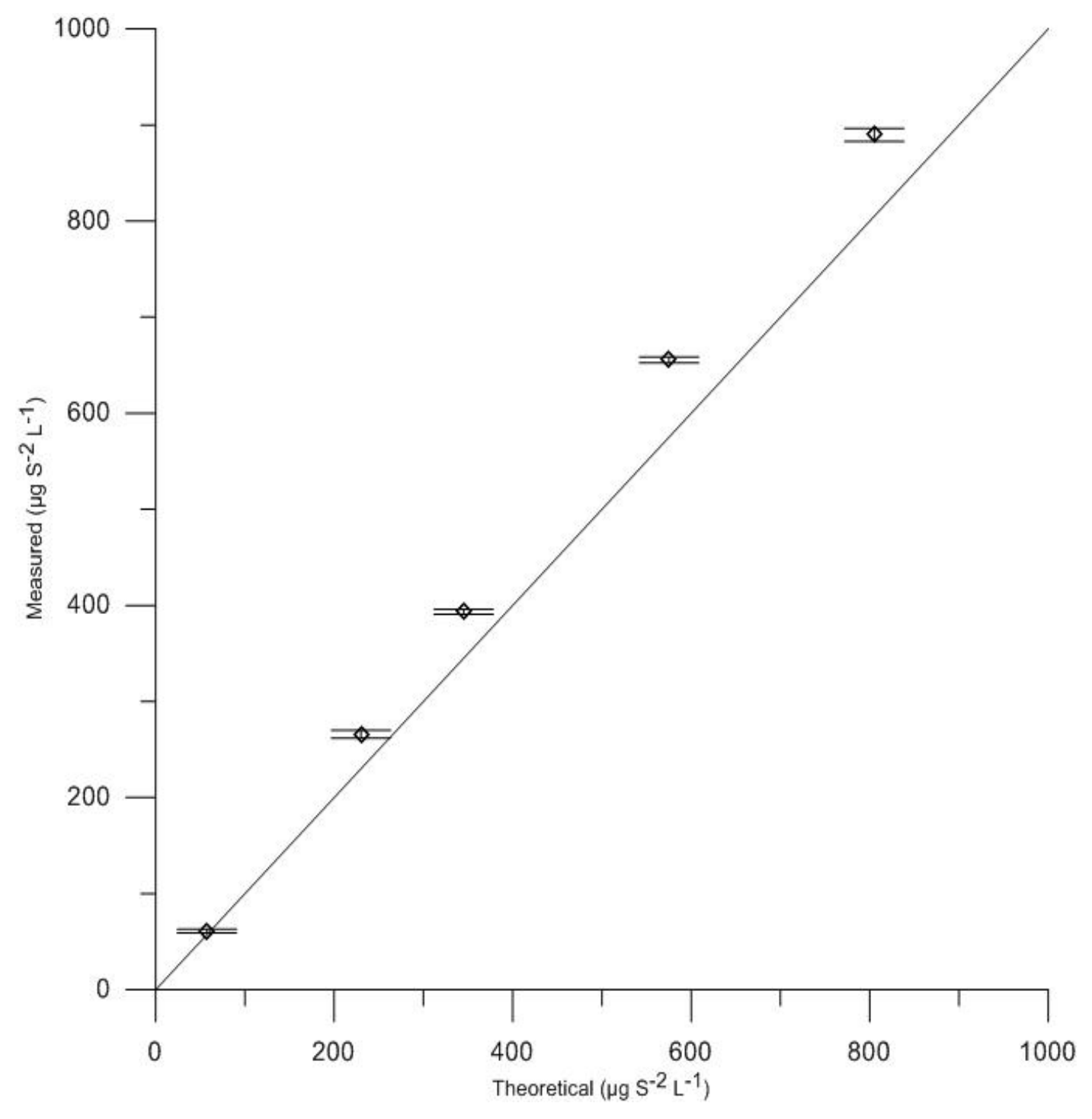

Figure 1 - Day 1 mean concentration measurements taken within 45 minutes of standard creation compared to theoretical concentrations. 


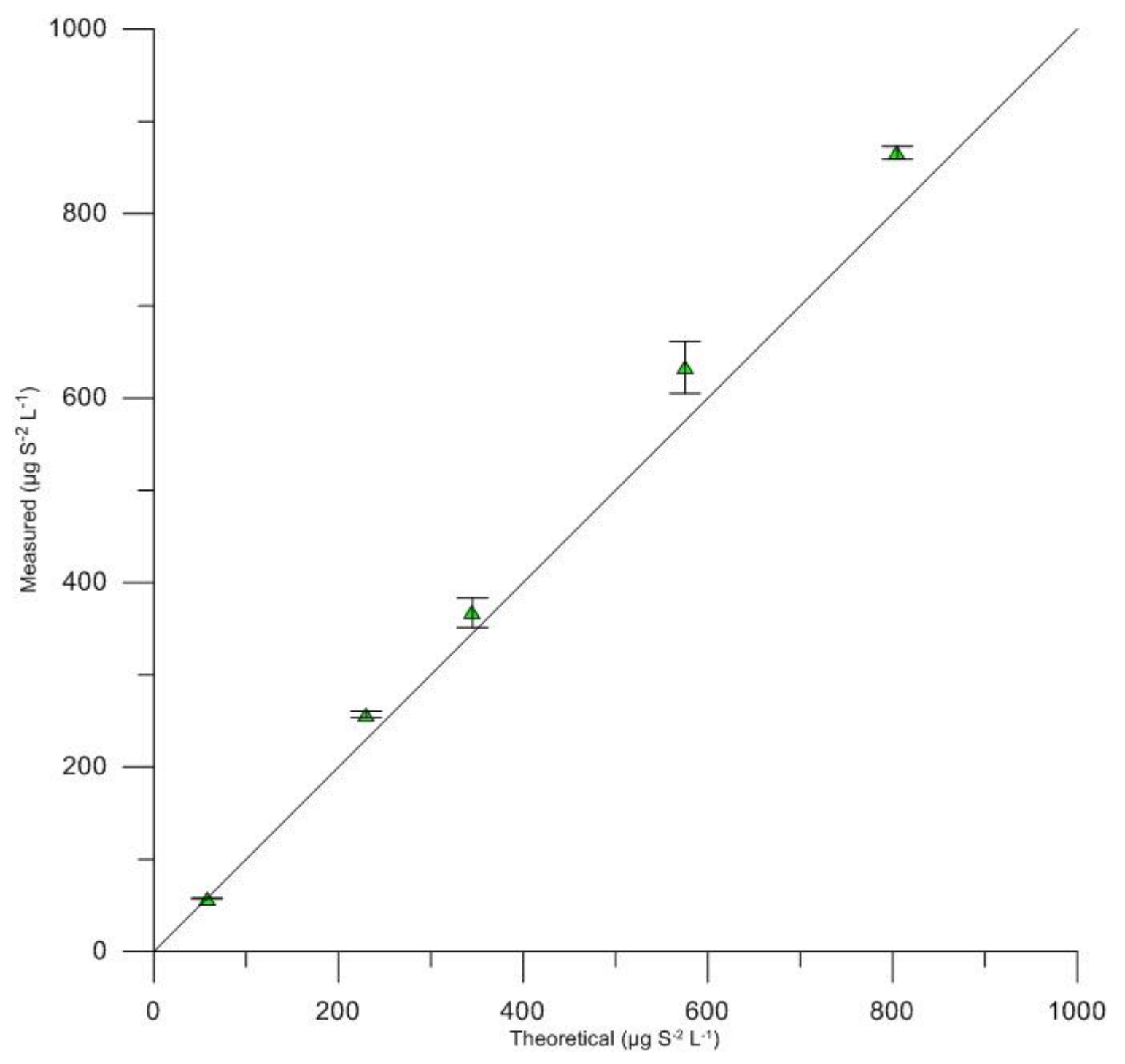

Figure 2 - Day 2 mean concentration measurements taken within 24 hours of standard creation compared to theoretical concentrations. 


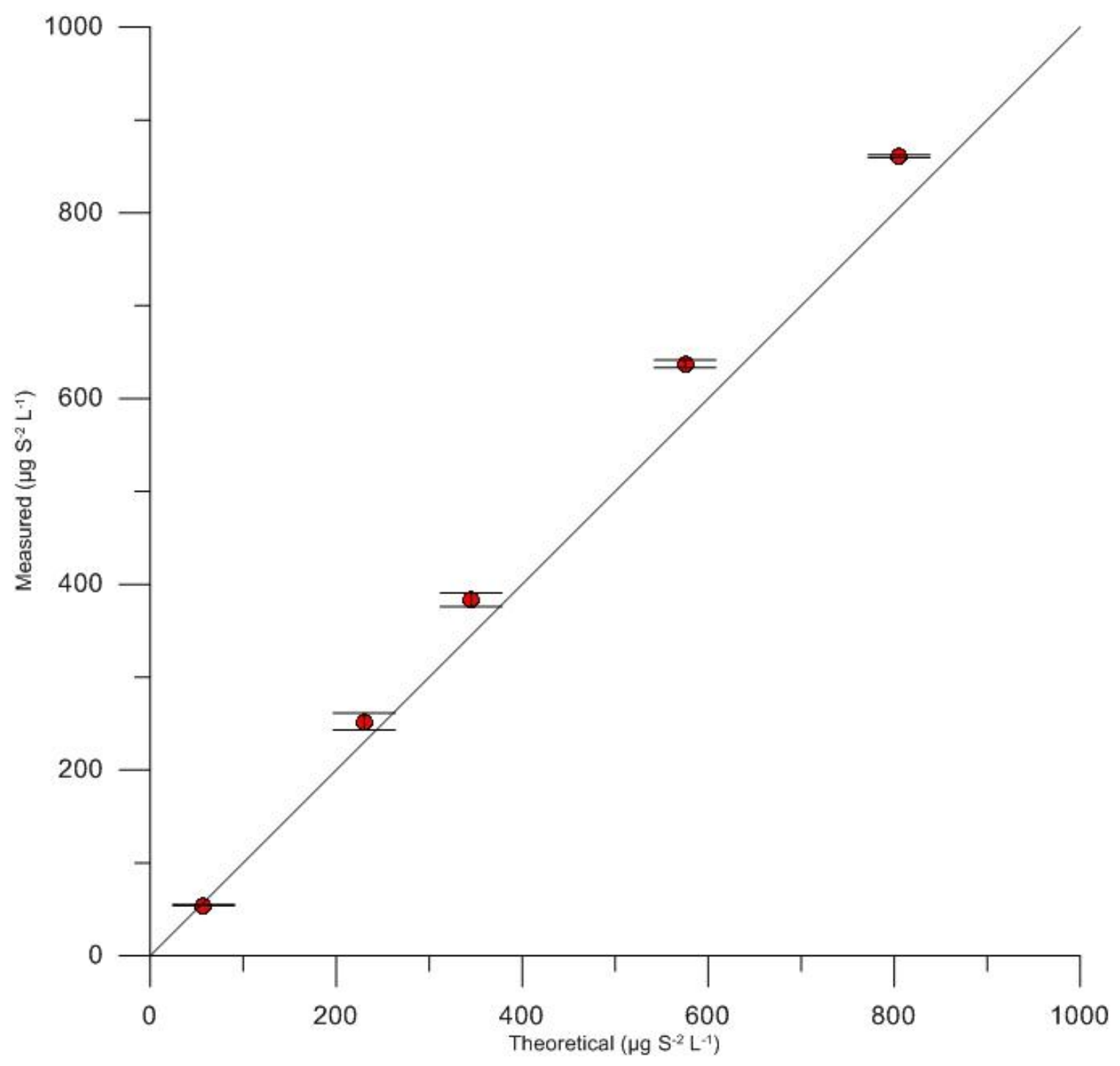

Figure 3 - Day 3 mean concentration measurements taken within 48 hours of standard creation compared to theoretical concentrations. 